\title{
Reneging on History? Playing the Court/Congress/President Civil Rights Game
}

\author{
William N. Eskridge, Jr. $\dagger$
}

Brenda Patterson is a woman of color. She worked for McLean Credit Umion as a file clerk and teller from 1972 until she was fired in 1982. Brenda Patterson sued McLean for racial discrimination based on its conduct towards her while she was an einployee. She testified at trial that her employer and its supervisors gave her more demeaning work than similarly situated white employees, passed over her for promotions given less qualified white einployees and did not even inform her of proinotion opportunities, demied wage increases routinely given other employees, and subjected her to gratuitous racial slurs, such as the opinion that "blacks are known to work slower than whites by nature."

Section 1981 of title 42 provides that all persons "shall have the saine right . . . to make and enforce contracts . . . as is enjoyed by white citizens."2 Brenda Patterson's claim asserted that the racial harassment she experienced while a McLean Credit Union employee violated her right "to niake and enforce contracts," in this case, her employment contract. The district court refused to submit her claim to the jury on the ground that racial harassnient relating to conditions of employment is not actionable under section 1981. On June 15, 1989, the United States Supreme Court, by a five-to-four vote, agreed with that interpretation. The Court in Patterson v. McLean Credit Union ${ }^{3}$ reasoned, in part, that

$\dagger$ Professor of Law, Georgetown University Law Center. B.A. 1973, Davidson College; M.A. 1974, Harvard University; J.D. 1978, Yale University. I am grateful to Ron Cass, Dan Farber, Phil Frickey, and Dick Posner for their comments on an earlier draft of this Article, and to John Ferejohn, Edward Schwartz, and Barry Weingast for informal conversations about the game theory used in the Article. I presented a version of this Article at the Legislation Section of the 1991 annual meeting of the Association of American Law Schools and received useful comments from the other panelists and participants. Dean Judy Areen and Associate Dean Wendy Webster Williams of the Georgetown University Law Center provided intellectual encouragement and financial support for my work on this Article, for which I am grateful. I appreciate the research assistance provided by Matt Bernstein and Ken Smurzynski.

1. Patterson v. McLean Credit Union, 491 U.S. 164, 213 (1989) (Brennan, J., concurring in the judgment in part and dissenting in part).

2. 42 U.S.C. $§ 1981$ (1988).

3. 491 U.S. 164 (1989). The facts of Brenda Patterson's case are taken from the trial transcript, summarized and quoted in $i d$. at 212-15 (Brennan, J., concurring in part and dissenting in part). 
interpretimg section 1981 to cover claims of on-the-job racial harassment would interfere with the operation of Congress' more recent regulation of workplace discrimination in title VII of the Civil Rights Act of 1964. ${ }^{4}$

Iromically, however, the Court was giving title VII a narrow construction. On June 5 by a five-to-four vote, the Court in Wards Cove Packing Co. v. Atonio ${ }^{5}$ held that in discriminatory impact cases under title VII, the einployee must prove not only a disparate impact, but also that the employer has no reasonable business justification for its discriminatory practices. ${ }^{6}$ On May 1 , a Court divided on other issues indicated in Price Waterhouse v. Hopkins ${ }^{7}$ that employinent decisions inotivated in part by prejudice do not violate title VII if the einployer can show after the fact that the same decision would have been made irrespective of the intentional discrimination. ${ }^{8}$

Following the trend set by Price Waterhouse and Wards Cove, the Court held in Martin v. Wilks ${ }^{9}$ that white employees who were not parties to the original litigation could nonetheless challenge court-approved consent decrees providing for affirmative action to remedy past violations of title VII and the fourteenth amendinent. The Martin case was decided by a five-to-four vote on June 12. That same day, a five-to-three majority held, in Lorance v. AT\&T Technologies, ${ }^{10}$ that title VII's statute of limitations for challenging semority plans begins to run when the plan is adopted, rather than when the plan is apphied to an individual. ${ }^{11}$ On June 22, a five-to-two vote of the Court in Independent Federation of Flight Attendants v. Zipes ${ }^{12}$ held that title VII does not provide for the statutory award of counsel fees against intervening defendants unless the intervenors' action is frivolous. ${ }^{13}$

These six Supreme Court decisions of May and June 1989 triggered a national pohitical debate. Each decision created practical difficulties for plaintiffs seeking relief for workplace discrimination under either title VII or section 1981. As a group, the decisions appeared an effort by five Justices $^{14}$ to narrow the protections provided by federal law for work-

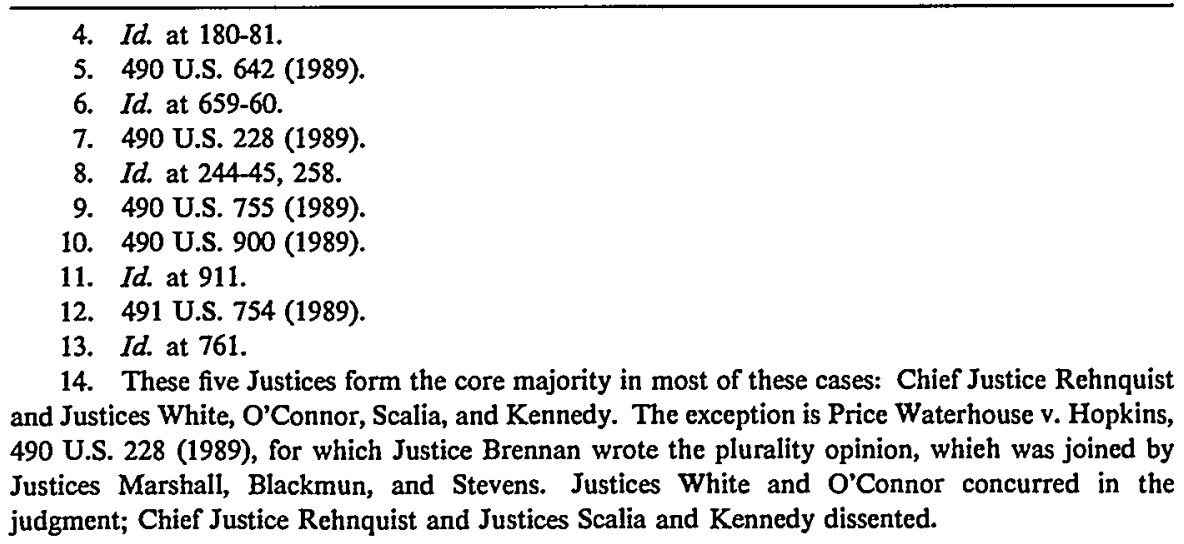


place discrimination. Civil rights groups in Washington, D.C., immediately started to devise legislation to overrule as many of the decisions as possible. Legislation was introduced in February 1990 to overrule all six decisions, as well as three earlier Supreme Court decisions that also affected workplace discrimination lawsuits. ${ }^{15}$ Congress passed the legislation, with amendments, in early October. The President vetoed the bill on the grounds that it did more than just overrule the unpopular decisions, and Congress was not able to override the veto. The debate continues. Similar legislation has been introduced in the 102nd Congress. ${ }^{16}$

The debate over the proposed Civil Rights Act of 1990 dramatizes the centrality of statutes and their interpretation to the nation's civil rights ${ }^{17}$ agenda. The debate also raises issues about the nature of statutory interpretation and the role of Congress. What interests ine about the 1990 debate is the rlietoric about the dynamics of Court/Congress interaction in the implementation of civil rights statutes. Consider this representative passage that appeared during the House discussion:

One thing is true about our history, and that [is] there always has been an ever-continuing struggle, a struggle for freedom and justice and equality.

... And by the 1960 's we reached a consensus, a consensus that we would move in a direction that would allow the doors to be opened and allow remedies to be put in place and say that discrimination was wrong.

For 25 years that process worked. Then $\mathrm{m} 1988$ and 1989 a series of court decisions came about that changed that fundamental process and those definitions. ${ }^{18}$

Such rhetoric whiggishly oversimplifies the Court/Congress interaction over civil rights.

Certainly the proposed Civil Rights Act of 1990 was unprecedented in its sweeping reform of the civil rights agenda. The Act, however, did not einerge out of thin air as a simple retort to Patterson and the other decisions. Actually the Act was the culmination of a fifteen-year process during which the political preferences of the Court and Congress have diverged. As I argue in more detail in Part I, the "consensus" of the

15. The three cases were: Crawford Fitting Co. v. J.T. Gibbons, Inc., 482 U.S. 437 (1987) (limiting reimbursement by losing party of prevailing party's expert witness fees); Evans v. Jeff D., 475 U.S. 717 (1986) (Civil Rights Attorney's Fees Awards Act of 1976 does not prohibit waiver of attorney's fees in exchange for settlement of case on the merits); Library of Congress v. Shaw, 478 U.S. 310 (1985) (title VII's allowance of reasonable attorney's fees to prevailing party does not provide for reeovery of interest from government).

16. See H.R. 1, 102d Cong., 1st Sess., 137 Cong. REC. H53 (daily ed. Jan. 3, 1991).

17. I am using the term "civil rights" in this Article to refer to measures attacking discrimination. I do not limit the discussion to racial discrimination, and several of the issues tracked in this Article relate to discrimination against women, the aged, and the handicapped. (I do not address legislation and decisions dealing with other civil rights, such as freedom of speeeh and association, criminal procedure rights, and various privacy protections.)

18. 136 ConG. REC. H6765 (daily ed. Aug. 3, 1990) (statement of Rep. Gray, D-Pa.). 
1960s was largely driven by the Court and the President. The consensus was the coincidence of leftward noveinent on civil rights by a Browninspired Warren Court, by a Presidency that came to pursue the Brown revolution aggressively, and by a Congress slowly overcoining the longstanding Southern obstruction of civil rights legislation. This consensus began to break down in the 1970s. The Court and the Presidency moved to the right while Congress and the relevant coininittees inoved to the left. Between 1976 and 1988, this divergence of opinion inanifested itself in a series of legislative overrides of Supreme Court decisions. At times, the acrimony between the branches was just as intense as that in the 1990 debate.

The rhetoric quoted above also wrongly assumes a inechanical role for the Court. The Congressinan seeins shocked that the Court "changed that fundamental process" by which civil rights laws had been enforced smce the 1960s. Much of Congress' criticisin of the 1989 decisions accused the Court of ignoring the original legislative intent in title VII. In iny view, this criticism is off the inark. Statutory interpretation is an inherently dynamic process: the text evolves as it is interpreted. The Court's interpretation of our civil rights laws has been particularly dynamic. ${ }^{19}$ Thus, Congress' objection should not be that the Court has changed the statute, but that the Court has changed it in ways the current legislative inajorities do not like.

To be sure, traditional theory einphasizes a mechanical approach to statutory interpretation under which the Court is nothing inore than the "honest agent" of Congress. ${ }^{20}$ However, the Constitution itself considers the Court a co-equal branch of the national governinent. Indeed, at least some of the original constitutional debates considered the Court a political branch, whose statutory as well as constitutional interpretations would serve as checks on the other branches. ${ }^{21}$ Part II of this Article adopts that original constitutional perspective and develops a model of the Court as a political actor in statutory interpretation. The model is based upon a game played by the Court, Congress, and the President in statutory implementation. Part II uses the gaine inodel as a way of understanding the historical evolution of the Court/Congress/President interaction for civil rights statutes froin 1962 to 1990.

The model suggests that the Court's influence on policymaking was

19. This is the argument in Eskridge, Dynamic Statutory Interpretation, 135 U. PA. L. REv. 1479 (1987), and subsequent articles.

20. This theory, too, has been vigorously criticized. For a variety of perspectives on the honest agent metaphor and its inability to constrain judicial discretion, see Eskridge, Spinning Legislative Supremacy, 78 GEO. L.J. 319 (1989); Farber, Statutory Interpretation and Legislative Supremacy, 78 GEO. L.J. 281 (1989); Posner, Legal Formalism, Legal Realism, and the Interpretation of Statutes and the Constitution, 37 CASE W. Res. L. Rev. 179 (1986).

21. See, e.g., The Federalist No. 78 (A. Hamilton). 
Inost significant at two points: at the period's beginning (1962-72), when the Court was to the left of Congress and relevant coinmittees, and at the period's end (1981-90), when both the Court and the President were significantly to the right of Congress and its committees. The inodel's success in explaming the Court/Congress/President interaction reaffirms the original constitutional understanding that the Court and the President and the Congress (not Congress alone) would determine statutory policy. The inodel also predicts that, given the likehhood that the Court will remain to the right of Congress, the most important variable for civil rights policy in the 1990s will be the President's agenda.

Part III explores some norinative and doctrinal miphcations of these game theoretic dynamics. In particular, Part III explores the model's suggestion that the Court is a pohtical actor implementing its own preferences about civil rights policy. This suggestion involves a rethinking of what we inean by "judicial activisin." The model suggests that the Court tends to slight the preferences of enacting Congresses im favor of the current Congress, which is a form of activism. I argue, further, that the Rehnquist Court has been more activist than the Burger and Warren Courts, for so far the Rehnquist Court, unlike the Burger and Warren Courts, has also tended to slight current congressional preferences. This activism has made Congress more willmg to overrule the Court's interpretations of civil rights statutes. An important question for the 1990 s is whether the Court will curtail its activism. If it does not, Congress might reduce the Court's role im civil rights cases by imposing new procedural requireinents on the Court and by shifting interpretive power froin the Court to alternative fora.

\section{I \\ A Conventional Political History of the Court/ Congress/President INTERACTION ON CiviL RightS ISSUES, 1962-90}

Traditional interest group and institutional theories identify three dynamic eleinents of the Court/Congress/President interaction in civil rights statutes in the last thirty years. First is the changing nature of the Democratic majority in Congress, from a majority whose leadership and meinbership were sharply divided on civil rights issues, to a sohdly liberal inajority on such issues. The second element is the developinent of a strong, institutionalized civil rights lobby aligned with the members of the relevant committees. The third is a shift of the Court's and the President's preferences on civil rights issues, from the left of Congress to the right of Congress.

In the 1960s, the Court and the Presidency pushed civil rights statutes in a liberal direction. Congress generally went along with the 
judicial and presidential initiatives, and there was surprisingly little open conflict between the Court and Congress. This changed in the mid1970s, however, as Congress moved to the left and the Court, less sharply, to the right. Congress started to override soine of the Court's statutory civil rights decisions in the 1970s. Through the 1980s, when the President was aligned with the Court, the Court has shifted drannatically to the right, and there has been a fair amount of conflict between Congress on one side, and the Court and President on the other.

\section{A. Court/Congress/President Cooperation: 1962-72}

In the 1950s, the federal government became cautiously interested in creating a progressive national civil rights pohicy. ${ }^{22}$ Sporadically progressive on civil rights issues, the Eisenhower administration created the Civil Rights Division of the Departinent of Justice; deployed armed forces to enforce desegregation decrees in Little Rock, Arkansas; appointed progressive, Brown-enforcing federal judges in the South; and pressed for national civil rights legislation in 1957 and 1961. The legislation that emerged in those two years was watered down in the legislative process because Southern Deinocratic opposition was strategically placed (especially in the Senate) and because the adininistration and the Deinocratic congressional leadership lacked the intense resolve needed to pass legislation.

The Warren Court contributed little to the evolution of statutory policy durmg this period. It was preoccupied with the frustrating scliool desegregation battle, where it liad only vague nineteentli-century statutes and unhelpful precedents to interpret. Moreover, the Justices could not agree on how activist the Court should be on civil rights. ${ }^{23}$

All three branclies, but inost notably the Presidency and the Supreine Court, shifted to the left in the 1960s. By 1963, the Kennedy adininistration had made enactinent of a coinprehensive civil rights statute a top priority. President Jolinson pressed for inajor civil rights legislation in every year of his adıninistration. ${ }^{24}$ As for the legislative branch,

22. For a brief history of civil rights policy in this period, see H. GRAHAM, THE CiviL RIGHTS ERa: Origins and Development of National Policy, 1960-1972, at 16-24 (1990). For additional material on earlier developments during the Truman administration, see To SECURE These Rights: The Report of the President's Committee on Civil Rights (1947).

23. Chief Justice Warren (1953-69) and Justices Black (1937-71), Douglas (1939-75), and Brennan (1956-90) were activist on civil rights issues in this period. Justices Frankfurter (1939-62), Clark (1949-67), Harlan (1955-70), Whittaker (1957-62), and Stewart (1958-81) were less so. See generally B. SchWARTZ, SuPER CHIEF: EARL WARREN AND His SuPreme CourT-A Judicial BlograpHY 175-96, 204-17, 252 (1983) (Court polarized during 1956-58 between Frankfurter wing and a Black-Brennan-Douglas-Warren wing, sarcastically dubbed "B.B.D. and W." by Frankfurter); 4 ENCYClopedia of the American Constitution 2023-31 (L. Levy, K. Karst \& D. Mahoney eds. 1986) (discussing the Warren Court).

24. Specifically, President Johnson carried forth President Kennedy's civil rights bill in 1963, 
the Democratic Party remained sharply split on civil rights issues throughout the 1960s, though its congressional leadership was inore hberal than it had been in the 1950s. ${ }^{25}$ While the inedian Democrat in Congress inoved somewhat to the left on civil rights issues during this period, ${ }^{26}$ opponents of civil rights legislation controlled solne of the critical committees. ${ }^{27}$ On the Court, sentiments shifted drainatically to the left after 1962, mainly due to changes in persoimel. ${ }^{28}$ The retireinent of

signing the landmark Civil Rights Act in 1964; in addition, he introduced and procured enactment of the Voting Rights Act in 1965, introduced and pushed unsuccessfully for a second omnibus civil rights statute in 1966 and 1967 (but was able to procure enactment of the Fair Housing Act in 1968-originally title IV of the 1966 and 1967 comprehensive bills), and introduced and procured enactment of the Age Discrimination Act of 1967. See generally H. GRAHAM, supra note 22, at 125300.

25. Majority Leader Mike Mansfield (D-Mont.), 1961-73, was more liberal on civil rights matters than Majority Leader Lyndon Johnson (D-Tex.), 1955-61. See generally Davidson, Senate Leaders: Janitors for an Untidy Chamber?, in CONGRESS RECONSIDERED 225, 228-32 (L. Dodd \& B. Oppenheimer eds. 1985) (contrasting Johnson's and Mansfield's leadership styles); Stewart, Two Strategies of Leadership: Johnson and Mansfield, in CONGREssional BEHAVIOR 61 (N. Polsby ed. 1971) (describing the strikingly different approaches that the two had to the job of Senate Democratic majority leaders). Speaker of the House McCormack (D-Mass.), 1962-71, was more liberal on civil rights matters than Speaker Sam Rayburn (D-Tex.), 1940-47, 1949-53, 1955-61. See Peabody, Party Leadership Change in the United States House of Representatives, in NEw Perspectives on the House of Representatives 359, 388-89 (R. Peabody \& N. Polsby eds. 1969). The Speaker in the 1960 s also began to exercise greater power over the Rules Committee. See, e.g., N. MACNEIL, Forge of Democracy 412-47 (1963) (detailing the packing of the House Rules Committee in 1961).

26. Taking into account voting on civil liberties issues generally, which would include first amendment and not just civil rights/antidiscrimination protection, the Democratic record is more stable. See Sinclair, Agenda, Policy, and Alignment Change From Coolidge to Reagan, in CoNGress RECONSIDERED, supra note 25, at 291, 301-04 (discussing Democratic and Republican voting records ou civil liberties from 1953 to 1968). For a discussion of the importance of the median legislators, see infra note 197.

27. Representative Howard W. Smith (D-Va.) chaired the House Rules Committee until 1967, succeeded by William Colmer (D-Miss.). Although the Southern Democrats did not hold a majority on the Rules Committee, they were able to use the power of the chair and other senior members to slow down or kill civil rights legislation throughout the 1950s and 1960s. See N. PolSBY, Congress AND THE Presidency 149-52 (3d ed. 1976) (describing Smith's use of the powerful Rules Committee to thwart civil rights legislation, and the Democratic caucus' attempt to make the Rules Committee better reflect the will of the majority). Representative Emanuel Celler (D-N.Y.) chaired the House Judiciary Committee until 1973. Celler was strongly on the left in civil rights matters, as was a solid majority of that committee throughout the 1960 s. See C. WhalEN \& B. Whalen, The Longest Debate: A Legislative History of THE 1964 Civil Rights ACt 2967 (1985) (Celler and the Judiciary Committee deliberations on the 1964 Act).

Senator James Eastland (D-Miss.) chaired the Senate Judiciary Committee from the 1950s until 1979, and through most of the 1960s about half of the committee (Southern Democrats Eastland, McClellan, Ervin, and Smathers, plus conservative Republicans Dirksen, Hruska, and Thurmond) was center-to-right on civil rights matters. Senator Lister Hill (D-Ala.) chaired the Committee on Labor and Public Welfare until 1969, but the composition of the committee was strongly to his left. To see the membership of the House and Senate committees during this period, see the Congressional Quarterly Almanac for each of the relevant years.

28. The key event was the retirement in 1962 of Justice Frankfurter, the leader of the Court's cautious wing, and his replacement with Justice Arthur Goldberg (1962-65). Together with the Warren Court's core of four civil rights activists (Justices Warren, Douglas, Black, and Brennan), 
Chief Justice Warren and resignation of Justice Fortas resulted in a rightward shift in 1969. Nevertheless, the Court in 1971 was still substantially to the left of its position before 1962 .

The national shift to the left was reflected in the significant, Presidency-led enactment of the Civil Rights Act of 1964 and the Voting Rights Act of $1965,{ }^{29}$ and the Court's lopsided votes upholding the constitutionality of both statutes. ${ }^{30}$ At the same time, the Supreme Court began interpreting Reconstruction era civil rights statutes dynamically to expand civil rights protections without waiting for legislative updating. In Louisiana v. United States, ${ }^{31}$ a unanimous Court interpreted the Enforcennent Act of $1870^{32}$ in a consciously dynamic way to invalidate a hiteracy test based upon its potential as well as its actual effect upon the fundamental right to vote. ${ }^{33}$ Civil rights leaders and the Johnson administration used Louisiana to prod Congress to expand statutory protection by enacting the Voting Rights Act. ${ }^{34}$

In United States v. Guest, ${ }^{35}$ the Court hiberally interpreted another post-Civil War statute to criminalize some private conspiracies to deprive civil rights activists of their fourteenth amendment rights. ${ }^{36}$ The Court

Justice Goldberg gave the activist wing a working majority on most civil liberties issues. See $\mathrm{B}$. SCHWARTZ, supra note 23, at 445-50; 2 ENCYCLOPED1A OF THE AMERICAN CONSTITUTION, supra note 23 , at $848-49$. The working majority continued when Justice Goldberg retired and was replaced with Justice Abe Fortas (1965-69), and the Court moved further to the left when Justice Thurgood Marshall replaced Justice Clark in 1967. See 3 id. at 1209-11. Justice Black moved discernibly to the right in the later 1960 s, but after the appointment of Justice Marshall, Black's vote was not necessary for the progressive working majority. See B. ScHWARTZ, supra note 23, at 629-79.

29. For accounts of the Civil Rights Act of 1964, see H. GRAHAM, supra note 22, at 74-152; C. WhaleN \& B. WhaleN, supra note 27. For accounts of the Voting Rights Act of 1965, see H. GraHAM, supra note 22, at 162-76; S. LAWSON, BLACK BaLlots: Voting RighTS IN THE SouTH, 1944-1969, at 307-22 (1976). See generally A. Thernstrom, Whose Votes CounT? (1987).

30. See South Carolina v. Katzenbach, 383 U.S. 301 (1966) (9-0 votc); Katzenbach v. McClung, 379 U.S. 294 (1964) (9-0 vote); Heart of Atlanta Motel, Inc. v. United States, 379 U.S. 241 (1964) (9-0 vote).

31. 380 U.S. 145 (1965).

32. Act of May 31,1870 , ch. 114, 16 Stat. 140 (current version at 42 U.S.C. $\S 1971$ (a) (1988)).

33. This is not a test but a trap, sufficient to stop even the most brilliant man on his way to the voting booth. The cherished right of people in a country like ours to vote cannot be obliterated by the use of laws like this, which leave the voting fate of a citizen to the passing whim or impulse of an individual registrar.

Louisiana, 380 U.S. at 153; cf. Lassiter v. Northampton Election Bd., 360 U.S. 45, 51 (1959) (upholding a state literacy test against similar statutory and constitutional challenge, but suggesting that Congress could constitutionally prohibit the practice through affirmative legislation).

34. See Voting Rights: Hearings on H.R. 6400 Before Subcomm. No. 5 of the House Comm. on the Judiciary, 89th Cong., 1st Sess. 13-18 (1965) (statement of Nicholas Katzenbach, Attorney General of the United States) (asserting the constitutionality of the bill, and citing Louisiana in support), $469-98$ (discussing and inserting into the record Louisiana).

35. 383 U.S. 745 (1966).

36. Id. at 754-56, 759 n.17; see also United States v. Price, 383 U.S. 787 (1966) (extending criminal liability for deprivation of civil rights to private parties in conspiracy with state officials). 
was closely divided on the statute's exact reach, ${ }^{37}$ but a majority called upon Congress to expand the statute to reach a greater number of private conspiracies. $^{38}$ Title V of President Johnson's omnibus 1966 civil rights bill followed the Court's suggestion precisely. ${ }^{39}$ The House passed the bill in 1966, but an incipient end-of-session Senate filibuster killed it. The same bill was resubmitted in $1967 .^{40}$ The House passed the title V portion in 1967, and in 1968 the House bill became the mechanism by which most of the 1966 administration proposals, mcluding the protection of civil rights workers, were enacted into law. ${ }^{41}$

Although title VIII, which established rights to nondiscrimination in liousing, was the centerpiece of the'Civil Riglits Act of 1968, the Court dynamically interpreted a inucli earlier statute to afford victims of sucl discrimination significantly greater protection. Within weeks of title VIII's enactment, the Supreme Court in Jones v. Alfred H. Mayer Co. ${ }^{42}$ interpreted the Civil Riglits Act of 1866 to provide parallel remedies. Section 1982 of title 42, the current codification of part of the 1866 Act, protects aganist racial discrimination in the sale, lease, or other conveyance of real or personal property. After making a detailed historical interpretation of section 1982 in its original form as part of the 1866 Act, $^{43}$ the Court held that tlie statute applied to more than state action: It lield tlie statute coinpreliended purely private discrimination as well. ${ }^{44}$

Following the lead of lower courts, the Supreine Court similarly

37. Guest, 383 U.S. at 782 n.6 (Brennan, J., joined by the Chief Justice and Justice Douglas, concurring in part and dissenting in part).

38. See id. at 782-83, 786; id. at 762 (Clark, J., concurring) ("[T]here now can be no doubt that the specific language of [the Fourteenth Amendment] empowers the Congress to enact laws punishing all conspiracies-with or without state action-that interfere with Fourteenth Amendment rights.").

39. See H.R. 14765, 89th Cong., 2d Sess. (1966); see also Civil Rights, 1966: Hearings Before Subcomm. No. 5 of the House Comm. on the Judiciary, 89th Cong., 2d Sess. 1073 (1966) [hereinafter Civil Rights, 1966 Hearings] (title V is "a responsible answer to the Guest case"); id. at 1129-69 (Guest opinions inserted into the hearings record), 1097-128 (also inserting language from the opinions in United States v. Price, 383 U.S. 787 (1966)). Title V was written not only to codify and expand upon Guest, but also to modify the interpretation of seetion 241 in United States v. Screws, 325 U.S. 91 (1945). See Civil Rights, 1966 Hearings, supra, at 1074.

40. See H.R. 5700, 90th Cong., 1st Sess. (1967); S. 1026, 90th Cong., 1st Sess. (1967). Soon after its introduction, the omnibus bill was broken up into separate bills, each focusing on one of the titles of the original bill. $S .1362$ embodied title $V$, but it was never reported from committee. H.R. 2516 embodied title $\mathrm{V}$ and was passed by the House in 1967, with amendinents and after the House had passed an anti-riot bill.

41. See Act of Apr. 11, 1968, Pub. L. No. 90-284, 82 Stat. 73.

42. 392 U.S. 409 (1968).

43. See id. at 422-36. The dissenting opinion's arguments for a contrary interpretation found much scholarly support. See, e.g., C. FAIRMAN, RECONSTRUCTION AND REUNION, 1864-1888, at 1258 (1971); Casper, Jones v. Mayer: Clio, Bemused and Confused Muse, 1968 Sup. CT. REv. 89.

44. Jones, 392 U.S. at 437 . One Justice found that current conditions alone required the Court's expansive interpretation. See id. at $444-49$ (Douglas, J., concurring) (describing continuing "badges of slavery"). 
reinterpreted section 1981 (the 1866 protection against racial discrimination in the making of contracts) to apply to purely private conduct. ${ }^{45}$ The Supreme Court's dynamic interpretation of sections 1982 and 1981 effectively gave more hiberal remedies for racial discrimination in housing and workplace discrimination than those afforded by title VIII and title VII, respectively.

Jones v. Mayer is one of the Warren Court's last statutory interpretation decisions. Jones was the only Supreme Court civil rights decision of this period to come close to a congressional override. Referring to the Civil Rights Act of 1866 by naine, Senator Hruska introduced an amendment during debate on the Equal Employment Opportunity Act of $1972^{46}$ to make title VII and the Equal Pay Act the exclusive remedies for workplace discrimination. ${ }^{47}$ The Hruska amendment would have overruled Jones v. Mayer insofar as it interpreted that part of the 1866 Act which is codified in section 1981. The amendment was rejected by a tie vote $\mathrm{m}$ the Senate, ${ }^{48}$ but a similar amendment was adopted on the House floor. ${ }^{49}$ In conference, the House backed off from its earlier position, and the final version of the 1972 Act had no exclusive remedy provision. $^{50}$

The progressive position of the late Warren Court and early Burger Court carried over into a dynamic and liberal interpretation of the 1960 s civil rights statutes. The key development in this period was the Court's policy shift from equality in opportunity (the focus of legislation in the 1960s) to equality of result (the practical focus of the legislation as implemented by the executive and the judiciary). ${ }^{51}$ In short, the Court deemphasized the original goal of creating a colorblind society where only individual qualifications matter, and emphasized the new goal of creating a society where group results matter and reference to race is appropriate in decisionmaking (in order to advance the substantive goal). In one case, Allen v. State Board of Elections, ${ }^{52}$ the Court by a seven-to-two vote interpreted the Voting Rights Act very liberally (and contrary to some important legislative history $)^{53}$ to invalidate even minor electoral changes

45. See Runyon v. McCrary, 427 U.S. 160 (1976) (private schools); Johnson v. Railway Express Agency, 421 U.S. 454 (1975) (private employers); Tillman v. Wheaton-Haven Recreation Ass'n, 410 U.S. 431 (1973) (community swimmiug pool).

46. Pub. L. No. 92-261, 86 Stat. 103.

47. 118 CONG. REC. $3172-73$ (1972).

48. Id. at 3373; see also id. at 3965 (lopsided vote on reconsideration).

49. See 117 CoNG. REC. 31,973, 32,111 (1971) (House discussion of Erlenborn amendment and its adoption).

50. See H.R. Conf. ReP. No. 899 , 92d Cong., 2d Sess. 17 (1972).

51. See generally H. GRAHAM, supra note 22, at 233-54 (early administrative shift to equal results); id. at 366-92 (judicial shift); A. THERNSTROM, supra note 29 (similar shift for voting rights).

52. 393 U.S. 544 (1969).

53. Compare id. at 564-69 (majority opinion's discussion of the legislative history) with id. at 
that potentially diluted the votes of blacks. ${ }^{54}$ In another case, a unanimous Court in Griggs v. Duke Power Co ${ }^{55}$ interpreted title VII to prohibit employinent practices that unintentionally have a disparate impact upon minorities.

Both decisions were dynamic interpretations of recently enacted statutes, developed by the Court in cooperation with the executive's vigorous implementation. They were also probably much more progressive than the view of a median Meinber of Congress. Yet when Congress extended the Voting Rights Act in $1970,{ }^{56}$ it made no effort to overrule Allen. Moreover, the House committee report used the Supreme Court's precedents to explain the statute's inportance and operation. ${ }^{57}$ When Congress amended title VII in 1972, both the House and Senate coinmittee reports explicitly endorsed the Griggs decision and its equality-ofresult iinplications. ${ }^{58}$

\section{B. Court/Congress Confrontations: 1972-86}

Escalating conflict between the Court and Congress over the nation's civil rights agenda marked the second decade of the modern statutory civil rights era. The inost important development during this era was the gradual riglitward drift of the Presidency and the Supreme Court, relative to Congress. The Nixon and Carter adininistrations progressively interpreted and vigorously enforced existing civil rights laws, albeit not as strongly as the Jolinson adninistration. ${ }^{59}$ The Reagan adıninistration, however, took a sharp turn to the right on most key

588-91 (Harlan, J., concurring in part and dissenting in part) (criticizing majority opinion's discussion of legislative history).

54. Section 5 of the Act requires "preclearance" by the Attorney General of any changes in the electoral systems of designated states whose prior systems had discriminated against black voters. Allen found that the following changes, among others, were covered by section 5: (1) a change from district to at-large voting for county officials; (2) a system change making a county official position only appointive rather than elective or appointive; and (3) rules making it harder for an independent candidate to get on the ballot. Id. at 550-51, 572 .

55. 401 U.S. 424 (1971) (proscribing employee tests not related to job performance).

56. Pub. L. No. 91-285, 84 Stat. 314 (1970).

57. H.R. ReP. No. 397, 91st Cong., 2d Sess. 2, 4-8, reprinted in 1970 U.S. Code ConG. \& ADMIN. NEWS 3277, 3278, 3280-84.

58. See H.R. REP. No. 238, 92d Cong., 1st Sess. 21-22 (1971), reprinted in 1972 U.S. CODE Cong \& ADMIN. News 2137, 2156-67; S. ReP. No. 415, $92 d$ Cong., 1st Sess. 14 (1971).

59. The Nixon and Carter administrations look alike, even though President Carter personally was more committed to civil rights than was President Nixon. The key boosters of the progressive agenda in both administrations were the Assistant Attorneys General for Civil Rights-Stanley Pottinger (Nixon) and Drew Days (Carter). In both administrations, my impression is that the Attorneys General-Mitchell, Kleindienst, Saxbe, and Levi (Nixon-Ford), and Bell and Civiletti (Carter)-were not as committed as the Assistants were. See generally H. GraHAM, supra note 22, at 301-420 (information on the Nixon period); Days, Fullilove, 96 YALE L.J. 453 (1987) (information on the Carter period). 
aspects of civil rights statutory interpretation. ${ }^{60}$

The Supreine Court's shift to the right was inore gradual. It began in 1972, when Justices Rehnquist and Powell first started to cast votes. ${ }^{61}$ Subsequent appointınents in 1975, 1981, and 1986 inoved the Court further to the right. ${ }^{62}$ Although there was internal inigration to the left by individual Justices during this saine period, ${ }^{63}$ by 1986 the Rehnquist Court stood significantly to the right of the early Burger Court.

In contrast, congressional preferences were inoving to the left after $1973 .{ }^{64}$ By the 1970 s, a reliable civil rights coahtion ennerged, consisting of a rainbow of unions, black groups, wonien's groups, and other public interest groups. The House Denocratic leadership and the relevant coinmittees agreed with the coalition's civil rights agenda. ${ }^{65}$ The story in the Senate was more conplicated, because from 1981 to 1987 it was controlled by Republicans. Although the Republican leadership in the Senate was not hostile to the civil rights coalition outright, it was never as strongly nor consistently allied with the coalition as was the Deniocratic leadership. The relevant Senate coinmittees continued to

60. I believe this generalization applies particularly to President Reagan, Attorney General Edwin Meese, and Assistant Attorney General William Bradford Reynolds. Cf. Days, The Courts' Response to the Reagan Civil Rights Agenda, 42 VAND. L. Rev. 1003 (1989) (noting judicial resistance to Reagan's anti-affirmative action agenda); Days, Turning Back the Clock: The Reagan Administration and Civil Rights, 19 HARv. C.R.-C.L. L. REv. 309 (1984) ("[T]he Reagan Administration has inadequately enforced and otherwise undermined, if not violated outright, settled law in the field of civil rights.").

61. These two Justices were appointed to succeed Justices Harlan and Black, respectively, in 1971, but did not begin to vote in cases until 1972 . One study has suggested that their pre-Court preferences were very conservative and that their Court votes simply refiected that conservatism. See Segal \& Cover, Ideological Values and the Votes of U.S. Supreme Court Justices, 83 AM. PoL. SCI. REV. 557, 560 table 1 (1989).

62. Id. at 559-60. The events were Justice Stevens' succession to Justice Douglas' seat (1975), Justice O'Connor's succession to Justice Stewart's seat (1981), Chief Justice Rehnquist's succession to Chief Justice Burger's seat (1986), and Justice Scalia's succession to Justice Rehnquist's seat (1986).

63. The most dramatic movement was by Justice Blackmun, who moved from being a "Minnesota Twin" of Chief Justice Burger, to become an ally of Justices Brennan and Marshall (the remnants of the 1960s Warren Court). Also gravitating to the left were Justices Stevens and Powell. On the other hand, Justice White gravitated to the right during the 1980s, as did Chief Justice Burger (who is, however, harder to pim down because of his strategic voting).

64. See Sinclair, supra note 26, at 306-11 (big jump in "civil liberties" support scores from 1969-72 to 1973-76, 1977-80, and 1981-82).

65. Liberal Peter Rodino (D-N.J.) chaired the Judiciary Committee from 1973 to 1989 , and with him was a solid liberal majority through those years. Liberal Carl Perkins (D-Ky.) chaired the Education and Labor Committee until 1985, when he was succeeded by the even more liberal Augustus Hawkins (D-Cal.); both chairs have enjoyed solid liberal majorities (including Republican votes) during these years. See the lists of Committee members and their ADA scores in M. BARONE, G. Ujifusa \& D. Matthews, The almanac of american Politics [hereinafter The Almanac of American Politics] published for 1974, 1976, 1978, 1980, 1982, 1984, 1986, and 1988. The Rules Committee, long controlled by Southern Democrats, fell under the control of the liberal Democratic leadership after 1973. See R. Davidson \& W. OlEszer, Congress AND ITS MemBers 273-74 (1983). 
have at least slim majorities in support of the coalition ${ }^{66}$ but did not have supportive committee chairs. ${ }^{67}$

As the Court moved to the right of Congress, the cooperative relationship between the Court and Congress began to erode. While there were no legislative overrides of the Court's civil rights statutory interpretations between 1962 and 1972, there were significant overrides between 1972 and 1986. Several Congressmen publicly accused the Court, not only of creating bad policy, but also of affirmatively misinterpreting legislative imtent.

\section{Civil Rights Attorney's Fees Statutes}

In the first of these legislative overrides, Congress reacted to the Court's own imvitation. In Alyeska Pipeline Service Co. v. Wilderness Society, ${ }^{68}$ a five-to-two Court lield that attorney's fees were generally not recoverable by "private attorneys general" enforcmg important public rights, unless the relevant federal statute contained explicit provisions for fee-shifting. ${ }^{69}$ The Court's decision liad what critics in Congress termed a "devastating impact" on civil rights hitigation. ${ }^{70}$ Witlin a year, Congress enacted the Civil Rights Attorney's Fees Awards Act, ${ }^{71}$ which provided for fee-shifting im favor of civil rights plaintiffs. The Voting Rights Act Extension im 1975 included similar fee-shiftmg provisions in response to Alyeska. ${ }^{72}$ The Equal Access to Justice Act of 1980, which permitted counsel fee awards against the federal government in some cases, was also in part a congressional response to Alyeska. ${ }^{73}$

66. Although the Judiciary Committee was chaired by conservative Senator Thurmond $(R-$ S.C.) during this period, liberals had a theoretical working majority, consisting of the eight Democrats and two moderate Republicans (Senators Mathias (R-Md.) and Specter (R-Pa.)). Although the Labor and Human Resources Committee was chaired by conservative Senator Hatch (R-Ut.) during this period, liberals here too had a working majority, consisting of the seven Democrats and two moderate Republicans (Senators Stafford (R-Vt.) and Weicker (R-Ct.)). For the members of these committees and their ADA scores, see THE AIMANAC Of AMERICAN Politics 1982,1984 , and 1986, supra note 65.

67. Senator Hatch chaired the Labor and Human Resources Committee, and Senator Thurmond chaired the Judiciary Committee. Both were much more conservative than the median Republican Senator, and are hardly on the same chart as the median Democratic Senator. See sources cited supra note 66 .

68. 421 U.S. 240 (1975).

69. Id. at $247-71$.

70. See H.R. Rep. No. 1558, 94th Cong., 2d Sess. 3 (1976); S. Rer. No. 1011, 94th Cong., 2d Sess. 4 (1976) [hereinafter Fees Act Senate Report] (Alyeska "created anomalous gaps in our civil rights laws"). Note that Alyeska itself did not involve civil rights hitigation (as I am using the term, see supra note 17), but I include it because the congressional overrides of it focused on civil rights litigation.

71. Pub. L. No. 94-559, 90 Stat. 2641 (1976) (codified at 42 U.S.C. § 1988 (1988)).

72. Pub. L. No. 94-73, § 402, 89 Stat. 400, 404 (1975); see S. REP. No. 295, 94th Cong., 1st Sess. 40-43 [hereinafter Voting Rights Senate Report], reprinted in 1975 U.S. CODE CONG. \& ADMIN. NEWS 774.

73. Pub. L. No. $96-481, \S 203$, 94 Stat. 2325 (codified as amended at 5 U.S.C. $\$ 504$ (1988)). 
The legislative debates indicate that a majority of Congress approved of the prior lower court fee-shifting practice and did not agree with Alyeska. "This bill creates no startling new remedy-it only ineets the technical requirements that the Supreme Court has laid down if the Federal courts are to continue the practice of awarding attorneys' fees which had been going on for years prior to the Court's May [1975] decision."74 Thus, Alyeska may be seen as stimulating Congress to enact into law what it already approved of, and expected, in practice.

\section{Age Discrimination Act Amendments of 1978}

The next congressional override was more confrontational. It involved the Court's imterpretation of the Age Discrimination in Einployment Act of 1967 (ADEA). The ADEA's stated purpose was to promote the employinent of older persons and to "prohibit arbitrary age discrimination in einployment."75 An issue arising under the ADEA was whether section 4(f)(2)'s exception for any "bona fide employee benefit plan ... which is not a subterfuge to evade" the statute ${ }^{76}$ justified the continuation of age-based inandatory retirement plans already in force when the ADEA was enacted. The Department of Labor's regulations implementing the Act narrowly construed the exception to protect only those plans that offered "equal benefit or equal cost" to older workers. ${ }^{77}$ The circuits had split on the issue of whether the exclusion validated some mandatory retirement plans. To resolve the split, the Senate committee, in a report dated October 12,1977, specifically approved the Fourth Circuit's decision in McMann v. United Airlines ${ }^{78}$ as the correct interpretation of the provision. ${ }^{79}$

Only two months later, the Supreme Court reversed the Fourth Circuit's McMann decision by a five-to-two inajority. The Court interpreted the ADEA in line with the cases the Senate cominittee had criticized and rejected in favor of the Fourth Circuit's interpretation. ${ }^{80}$ The dissenting opinion argued that the original expectations of Congress in

74. Fees Act Senate Report, supra note 70, at 4; see also id. at 1 ("The purpose of this amendment is to remedy anomalous gaps in our civil rights laws created by the United States Supreme Court's recent decision in [Alyeska] . . .."); Voting Rights Senate Report, supra note 72, at 42 ("The Alyeska decision created an unexpected and anomalous gap in our civil rights laws whereby awards of fees are barred in the most fundamental civil rights cases.").

75. Age Discrimination in Employment Act of 1967, Pub. L. No. 90-202, § 2(b), 81 Stat. 602 (codified at 29 U.S.C. $\$ 621(b)(1988)$ ).

76. Id. $\S 4(\mathrm{f})(2), 81$ Stat. 602,603 (codified at 29 U.S.C. $\S 623(\mathrm{f})(2)(1988)$ ).

77. See 29 C.F.R. $\$ \S 860.110,860.120$ (1976); see also Public Employees Retirement Sys. v. Betts, 109 S. Ct. 2854, 2862 (1989) (interpreting these sections).

78. 542 F.2d 217 (4th Cir. 1976) (ruling that ADEA proscribed mandatory retirement of employees at age 60 solely because of employee's membership in a retirement plan).

79. S. REP. No. 493, 95th Cong., 1st Sess. 10 (1977), reprinted in 1978 U.S. CoDE CoNG. \& ADMIN. NEWS 504, 513.

80. United Airlines v. McMann, 434 U.S. 192, 197-98 (1977). 
1967 had been to invalidate plans like United's. ${ }^{81}$ The majority responded that the statutory exception for bona fide plans was unambiguous. ${ }^{82}$

Predictably, Congress immediately overrode the Court's construction with the Age Discrimination in Employinent Act Amendments of 1978. ${ }^{83}$ Senator Javits (R-N.Y.), who had authored section 4(f)(2), explained that the Labor Department in its regulations, and not the Supreme Court, had correctly interpreted the section. ${ }^{84}$ The conference committee reiterated the ADEA's "original purposes" and the original legislative expectation that plans such as United's would be invalidated: "In [McMann] the Supreme Court held to the contrary ... . The conferees specifically disagree with the Supreme Court's holding and reasoning in that case." 85 This decisive overriding marked the beginning of the present Court/Congress conflict over the interpretation of civil rights laws.

\section{The Pregnancy Discrimination Act of 1978}

By a six-to-three vote, the Supreine Court in General Electric Co. v. Gilbert ${ }^{86}$ held that an einployer's exclusion of pregnancy-related disabihties from its employee disability plan does not violate title VII's proscription against discrimination " "because of [the] individual's . . . sex." "\$87 Had the Court looked to the exclusion's disparate impact as it had in Griggs, ${ }^{88}$ it might have reached a different conclusion, since excluding pregnancy-related conditions has an obvious gender-based effect. ${ }^{89}$ The Court, however, interpreted title VII in light of its decision in Geduldig $v$. Aiello, ${ }^{90}$ where it held that pregnancy-based state regulation does not violate the equal protection clause of the Constitution. ${ }^{91}$ Gilbert reasoned

81. Id. at 211-18 (Marshall, J., dissenting).

82. Id. at 199,203 . Ironically, the Court still responded (somewhat lamely) to the dissent's legislative history arguments. See id. at 199-202.

83. Pub. L. No. 95-256, § 2, 92 Stat. 189 (codified in scattered sections of 29 U.S.C. (1988)).

84. S. Rep. No. 493, 95th Cong., 1st Sess. 31 (1977).

85. H.R. CoNF. REP. No. 950, 95th Cong., 2d Sess. 8, reprinted in 1978 U.S. CoDE CoNG. \& ADMIN. NEWS 528, 529.

86. 429 U.S. 125 (1976).

87. Id. at 133 (quoting 42 U.S.C. \& 2000e-(a)(1) (1988)).

88. Griggs v. Duke Power Co., 401 U.S. 424 (1971).

89. There is a Griggs-based counterargument: Surveys suggested that firms spent more money on women's health plans even without pregnancy benefits, and the addition of pregnancy benefits increased the alrcady existing disparity even more in favor of female workers. See Legislation to Prohibit Sex Discrimination on the Basis of Pregnancy: Hearing on H.R. 5055 and H.R. 6075 Before the Subcomm. on Employment Opportunities of the House Comm. on Education and Labor, 95th Cong., 1st Sess. 84, 85-86 (1971) [hereinafter PDA House Hearings] (statement of G. Brockwel Heylin, labor relations attorney, Chamber of Commerce of the United States) (describing surveys).

90. 417 U.S. 484 (1974).

91. Gilbert, 429 U.S. at 134 (citing Geduldig, 417 U.S. at 494). 
that classifications based upon pregnancy divide the world into two groups: pregnant women versus men and nonpregnant women. Consequently, the rule did not exclude anyone from benefits solely on the basis of gender, and only "remove[d] one physical condition-pregnancyfrom the hist of compensable disabilities."92 Although the majority acknowledged that the exclusion was gender-related, it noted that the plaintiffs had failed to demonstrate that this exclusion was a pretext for sex-based discrimination. ${ }^{93}$ The Court's decision in Gilbert raised questions about the future viability of Griggs. ${ }^{94}$

The political response to Gilbert was swift and furious. The decision came down in December 1976, and within a week, women's organizations, progressive umions, civil rights groups, and several general public interest groups formed an umbrella lobbymg group, the Campaign to End Discrimination Against Pregnant Workers. ${ }^{95}$ Early in 1977, legislation was introduced in both chambers to overrule Gilbert by defining discrimination on the basis of gender to include pregnancy-based distmctions. $^{96}$ Hearmgs were leld in both chambers in April 1977.97 Although busmess and insurance groups vigorously opposed the new legislation, it was even more vigorously supported by the administration, labor unions and the AFL-CIO, various women's groups, and assorted civil rights and pubhic interest groups. The relevant committees enthusiastically reported the bills (though the House committee bowed to pressure from the National Conference of Catliolic Bisliops to add a proviso that employers would not have to pay for abortion-related expenses ${ }^{98}$ ).

The resultimg Pregnancy Discrimination Act (PDA) is notable in part because the key legislative players rushed to declare, witli unusual fervor, that the Court had mismterpreted title VII. The committee

92. Id.

93. Id. at 134-36.

94. Compare id. at 146 (Blackmun, J., concurring in part) (raising the issue of Griggs but refusing to join in any suggestion that it is not still good law) with id. (Stewart, J., concurring) (saying viability of Griggs is not an issue and stating that in any event the Court's opinion does not retreat from Griggs).

95. See PDA House Hearings, supra note 89 , at 30-42, 47.

96. H.R. 5055, 95th Cong., 1st Sess. (1977) (introduced by Rep. Hawkins (D.Cal.) with 81 sponsors) (superseded by H.R. 6075, 95th Cong., 1st Sess. (1977) (introduced by Rep. Hawkins with 119 sponsors by 1978, when the bill was reported)); S. 995, 95th Cong., 1st Sess. (1977).

97. See PDA House Hearings, supra note 89 (hearings held April 6, 1977, and June 29, 1977); Discrimination on the Basis of Pregnancy, 1977: Hearings on S. 995 Before the Subcomm. on Labor of the Senate Comm. on Human Resources, 95th Cong., 1st Sess. (1977) [hereinafter PDA Senate Hearings] (hearings held on April 26, 27, and 29, 1977).

98. See H.R. REP. No. 948, 95th Cong., 2d Sess. (Mar. 13, 1978) [hereinafter PDA House Report], reprinted in 1978 U.S. CODE CONG. \& ADMIN. NEwS 4749 . The Senate bill did not havc this proviso, see S. REP. No. 331, 95th Cong., 1st Sess. (1977) [hereinafter PDA Senate Report], and the House conference committce subsequently watered down the House version. See H.R. CoNF. REP. No. 1786, 95th Cong., 2d Sess. (1978), reprinted in 1978 U.S. CODE CONG. \& ADMIN. NEWS 4765. 
reports asserted that "the dissenting Justices [in Gilbert] correctly interpreted the Act."99 The statements of the PDA's sponsors were even stronger: "By concluding that pregnancy discrimination is not sex discrimination within the meaning of title VII, the Supreme Court disregarded the intent of Congress in enacting title VII. That intent was to protect all individuals from unjust employment discrimination, including pregnant women." 100

\section{The Voting Rights Act of 1982}

The next major confrontation between the Court and Congress followed the Court's decision in City of Mobile v. Bolden. ${ }^{101}$ The lower courts had invalidated, as a violation of the fifteenth amendment, the atlarge method of electing city commissioners in Mobile, Alabama. The Supreme Court reversed. The Court's plurality opinion ${ }^{102}$ admonished the lower courts for not considering the statutory issue first-whether the at-large system violated section 2 of the Voting Rights Act-but then held that section 2 merely "restated" fifteenth amendment requirements. ${ }^{103}$ The plurality opinion then found that the fifteenth amendment required that challengers to a voting mechanism prove a discriminatory intent in order to prevail. A fifth Justice articulated a different, and arguably more restrictive, fifteenth amendment standard. ${ }^{104}$ The dissenting Justices argued that the plurality's fifteenth amendment test represented a significant departure from the precedents established by the Warren Court and early Burger Court. ${ }^{105}$

Because there was no inajority opinion, Bolden provoked as much

99. PDA House Report, supra note 98, at 2; see also id. ("It is the Committee's view that [the EEOC] guidelines rightly implemented the Title VII prohibition of sex discrimination in the 1964 Act."); PDA Senate Report, supra note 98, at 2-3 (same, almost verbatim).

100. PDA Senate Hearings, supra note 97, at 1 (opeming statement of Sen. Williams (D-N.J.), committee chairman). Williams was also a key supporter of the 1964 Civil Rights Act. See also id. at 6-20 (statement of Sen. Bayh (D-Ind.)); id. at 20-23 (statement of Sen. Mathias (R-Md.)); PDA House Hearings, supra note 89, at 1 (opening statement of Rep. Hawkins (D-Cal.), committee chairman). Senator Bayh, then-Representative Mathias, and Representative Hawkins were all supporters of the 1964 Civil Rights Act.

101. 446 U.S. 55 (1980).

102. The plurality was authored by Justiee Stewart, $i d$. at 58 , one of the most conservative of the Warren Court Justices. See Segal \& Cover, supra note 61, at 561-62 (indicating Justice Stewart's relative conservatism as compared to Justices Warren, Brennan, Fortas, Goldberg, Marshall, and White). The opinion was joined by three of the four Nixon Justices, namely Burger, Powell, and Rehnquist. Justice Blackmun, the other Nixon appointee, concurred in the result. Bolden, 446 U.S. at 80-83. Justice Stevens, appointed by Ford, concurred in the judgment. Id. at 83-94. The three other Warren Court holdovers-Justices Brennan, Marshall, and White-dissented. Id. at 94-141.

103. Id. at 61 .

104. See id. at 83-94 (Stevens, J., concurring in the judgment).

105. See id. at 94 (White, J., dissenting); id. at 108-12 (Marshall, J., dissenting) (relying on White v. Regester, 412 U.S. 755 (1973), Burns v. Richardson, 384 U.S. 73 (1966), and Fortson v. Dorsey, 379 U.S. 433 (1965)). 
confusion as outrage. Decided in April 1980, Bolden came at the worst possible time for a legislative override. It was decided at the end of Congress' second session and in a critical presidential election year. As a consequence, Congress did not have adequate time to override Bolden, and so postponed serious consideration until 1981.

That year, Republicans took control of the Presidency and the Senate. Nevertheless, serious efforts were mounted early in the next Congress to override Bolden's interpretation of the Voting Rights Act. ${ }^{106}$ Hearings during the summer of 1981 yielded virtually unchallenged testimony from law professors, litigation groups, and groups in the civil rights coalition that Bolden was a radical departure from the Court's statutory, as well as constitutional, precedents and that Bolden had fashioned an approach to voting rights that was both confusing and counterproductive. ${ }^{107}$ With little open opposition, Congress overrode Bolden in the Voting Rights Act Amendments of 1982. ${ }^{108}$

Just as had occurred twice in 1978, the 1982 legislative override was accompanied by a congressional claim that it was defending the statutory status quo. Key legislators stated that the Court, not the Congress, had shifted policy direction; Congress was merely correcting the Court's erroneous interpretation. The Republican-controlled Senate Judiciary Committee put it most carefully:

While the Committee finds that Congress did not seek to include an intent test in the original provision of section 2, a plurality of four justices in [Bolden] thought that it did. The Court is the ultimate interpreter of laws once enacted. But in any event, there is no question that Congress may now decide that an intent requirement is inappropriate for section 2, and amend [the] statute to make that point clearly. ${ }^{109}$

\section{Rehabilitation Act Amendments of 1986}

In 1986, Congress enacted three different statutes to override three Supreme Court decisions, all involving the rights of handicapped Americans. The first of these overridings was fairly routine. In United

106. See H.R. 3112, 96th Cong., 1st Sess. 70 (1981) (introduced by Rep. Rodino (D-N.J.) on April 7); H.R. 3198, 96th Cong., 1st Sess. 72 (1981) (introduced by Rep. Hyde (R-Ill.) on April 9); S. 995, 96th Cong., 1st Sess. (1981) (introduced by Sens. Mathias (R-Md.) and Kennedy (D-Mass.)).

107. See Extension of the Voting Rights Act: Hcarings Before the Subcomm. on Civil and Constitutional Rights of the House Comm. on the Judiciary, 97th Cong., 1st Sess. passim (1981).

108. Pub. L. No. 97-205, § 3, 96 Stat. 131, 134 (codified at 42 U.S.C. § 1973 (1988)).

109. S. REP. No. 417,97 th Cong., 2 d Sess. 17 n.49, reprinted in 1982 U.S. CoDE CoNG. \& ADM1N. News 177, 194 n.49; see also id. at 26, reprinted in 1982 U.S. CoDE CoNG. \& ADM1N. NEws 177, 203 ("A fair reading of Bolden reveals that the plurality opinion was a marked departure from earlier Supreme Court and lower court vote dilution cases."); id. at 27, reprinted in 1982 U.S. CODE CONG. \& ADMIN. NEws 177, 205 ("The 'results' standard is meant to restore the pre-Mobile legal standard ...."). 
States Department of Transportation v. Paralyzed Veterans of America, ${ }^{110}$ the Court had interpreted section 504 of the Rehabilitation Act of 1973 to be inapphicable to air carriers. ${ }^{111}$ Within the year, Congress responded with the Air Carrier Access Act of $1986,{ }^{112}$ which authorized the Department of Transportation to develop regulations protecting handicapped people against discrimination. Unlike the PDA, the ADEA Amendinents, or the Voting Rights Act Amendments, this statute reflected congressional disagreement with the Court's outcoine, not its role in the case. ${ }^{113}$

The same cannot be said of Congress' response to Atascadero State Hospital v. Scanlon. ${ }^{114}$ By a five-to-four vote, the Court held that the Rehabilitation Act had not abrogated the states' eleventh amendment iminunity. The Court's holding was based upon its increasingly aggressive stance toward protecting state sovereign immunity. ${ }^{115}$ The decision greatly surprised Congress, which believed that it had specifically abrogated the sovereign immunity defense in the Act. Section 504 prohibited discrimination against the handicapped in "any program or activity receiving Federal financial assistance." 116 Obviously, this included many state prograins. Moreover, Congress had conducted its debates under the assumption that the states could be sued. ${ }^{117}$ Within a month of the Court's decision, a bill was introduced to override it. ${ }^{118}$ The override provisions were incorporated into the omnibus Rehabilitation Act Amendments of $1986 .^{119}$

The override of Atascadero was not a difficult decision for Congress. It considered the Court's interpretation simply wrong. "The Supreme Court's decision misinterpreted congressional intent," stated the conımittee report. "Such a gap in Section 504 coverage was never intended. It would be inequitable for Section 504 to mandate state compliance with

110. 477 U.S. 597 (1986).

111. Id. at 599 (quoting 29 U.S.C. § 794 (1982)).

112. Pub. L. No. $99-435,100$ Stat. 1080.

113. See S. REP. No. 99-400, 99th Cong., 2d Sess. 2 (1986) ("In recognition of the unique difficulties now faced by handicapped air travelers, [the bill] would mitigate the effect of $D O T$ v. PVA by amending section 404 of the Federal Aviation Act of 1958 to prohibit specifically discrimination against otherwise qualified handicapped individuals."), reprinted in 1986 U.S. CODE CONG. \& ADM1N. News 2328, 2330.

114. 473 U.S. 234 (1985).

115. See id. at 242 ("Our reluctance to infer that a State's immunity from suit in the federal courts has been negated stems from recognition of the vital role of the doctrine of sovereign immunity in our federal system.") (quoting Pennhurst State School \& Hosp. v. Halderman (Pennhurst In), 465 U.S. 89, 99 (1984)).

116. Id. at 245 (quoting 29 U.S.C. $\S 794$ (1988)).

117. See id. at 248 (Brennan, J., dissenting).

118. S. 1579, 99th Cong., 2d Sess. (1986) (introduced on Augnst 1 by Sen. Cranston (D-Cal.), with five cosponsors, including two liberal Republicans-Sen. Stafford (R-Vt.) and Sen. Weicker ( $R-$ Conn.)).

119. Pub. L. No. 99-506, $\S 1003,100$ Stat. 1845 (codified at 42 U.S.C. $\S 2000$ d-7 (1988)). 
its provisions and yet deny hitigants the right to enforce their rights in Federal courts when State or State agency actions are at issue." ${ }^{120}$ This reasoning was precisely that of the Atascadero dissenters, whose views the committee report endorsed.

\section{The Handicapped Children's Protection Act of 1986}

The third statutory override of 1986 also involved the rights of the handicapped. In Smith v. Robinson, ${ }^{121}$ the Court held that the Education of All Handicapped Children Act of 1975 (EHA) ${ }^{122}$ was handicapped children's exclusive source of rentedies. ${ }^{123}$ As a consequence, handicapped children could not sue under section 504 of the Rehabilitation Act, which offered the advantage of counsel fee awards to prevailing plaintiffs. ${ }^{124}$ Bills to overrule Smith $v$. Robinson were introduced within months of the decision and enjoyed substantial bipartisan support. Although bills passed both the House and Senate in 1985, the measure languished in conference for almost a year. The source of the delay was a provision in the Senate bill imposing linits on fee awards to publicly funded legal aid lawyers. ${ }^{125}$ In July 1986, after that issue was resolved, botli cliambers approved by voice vote the Handicapped Children's Protection Act (HCPA). ${ }^{126}$ Congressional rhetoric about being disappointed with the Court was not so keen for this bill as it had been in earhier overrides. Nevertheless, the committee report suggested that once again Congress agreed witl the dissentmg opinion. ${ }^{127}$

In overriding Robinson, however, Congress adopted a more tangible way of registering its disapproval. Enacted at the end of 1986, the HCPA provided that it would apply to all EHA actions pending on July 4, 1984 (the day before the Court's decision), as well as to all actions initiated after July $3,1984 .{ }^{128}$ This provision was not only a slap at the Court, but also triggered open presidential opposition and risked a veto. Nonetlieless, the President ultimately signed the bill, over his constitu-

120. S. REP. No. 99-388, 99th Cong., 2d Sess. 27-28 (1986).

121. 468 U.S. 992 (1984).

122. 84 Stat. 175 (codified as amended at 20 U.S.C. $\S 1400$ et seq. (1988)).

123. Robinson, 468 U.S. at 1009, 1021.

124. See id. at 1021.

125. See 1985 Cong. Q. Almanac 297; 1986 Cong. Q. Almanac 271-72.

126. Pub. L. No. 99-372, 100 Stat. 796 (1986) (codified at 20 U.S.C. $\S 1415$ (1988)).

127. See S. REP. No. 99-112, 99th Cong., 2d Sess. 2 [hereinafter HCPA Senate Report] ("The situation which has resulted from the Smith v. Robinson decision was summarized by Justices Brennan, Marshall, and Stevens in their dissenting opinion: 'Congress will now have to take the time to revisit the matter." " (quoting Robinson, 468 U.S. at 1031)), reprinted in 1986 U.S. CoDE Cong. \& ADMIN. NEws 1798, 1799.

128. Handicapped Children's Protection Act, $\S 5,100$ Stat. 798 (1986) (codified at 20 U.S.C. $\S 1415$ (1988)); see HCPA Senate Report, supra note 127, at 3, reprinted in 1986 U.S. CODE CONG. \& ADMIN. News 1800 . 
tional objections. ${ }^{129}$

\section{Court/Congress/President Conflict: 1985-90}

Even though no general preference shifts occurred in the late 1980s, the Court/Congress conflict heated up, intensified by inore presidential involvernent. The Court continued its rightward drift, with personnel changes in 1987 and $1990 .^{130}$ Congress moved to the left on civil rights matters after the 1986 election. ${ }^{131}$ The Presidency showed the most significant inoveinent by inpleinenting a virtually unprecedented confrontational strategy against civil rights legislation. Presidents Kennedy and Johnson had battled Congress for civil rights legislation; Presidents Nixon, Ford, and Carter had cooperated with Congress-driven initiatives in the 1970s. And, although the early Reagan administration had pubhicly expressed reluctance about the Voting Rights Amendments of 1982, it did not take a strong public position against the Rehabilitation Act Amendments of 1986 or the Air Carrier Access Act of 1986. The later Reagan administration and the Buslı administration reversed this trend, actively opposing inuportant congressional overrides of civil rights precedents, using the veto threat aggressively, and actually vetoing civil rights legislation for the first tine since Reconstruction.

\section{The Civil Rights Restoration Act of 1988}

The inost iniportant override since the PDA involved Congress' response to the Supreme Court's decision in Grove City College v. Bell. ${ }^{132}$ Title IX of the Education Amendments of 1972 prohibits sex discrimination in any "education program or activity receiving Federal financial

129. Statement on Signing S. 415 Into Law, 1986 PUb. PAPERS 1056 (Ronald Reagan, Aug. 5, 1986) ("The retroactive application of the act to cases that are no longer pending permits the Congress to displace the judicial function by interfering with a final judgment.").

130. The Court shifted to the right when Justice Kennedy succeeded Justice Powell in 1987, and Justice Souter succeeded Justice Brennan in 1990. Note that Segal \& Cover, supra note 61, at 56062 , list Justice Powell as more conservative than Justice Kennedy on civil liberties issues (including due process, freedom of expression, criminal justice as well as civil rights issues). In my opinion, on such issues as affirmative action, Justice Powell is more liberal. For example, Justice Powell joined the Court in Johnson v. Transportation Agency, 480 U.S. 616 (1987), whereas Justice Kennedy has joined opinions, such as Wards Cove, that are hostile to affirmative action.

131. The Democrats picked up eight Senate seats and control of the Senate. That re-established a liberal civil rights leadership in the Senate (Senators Mitchell and Cranston), and strengthened liberal control over the key committees. Senator Biden's (D-Del.) Judiciary Committee has had a liberal majority of nine to five on most issues (the eight Democrats plus Senator Specter (R-Pa.)). Senator Kennedy's Labor and Human Services Committee has had a liberal majority of eleven to five on most issues (nine Democrats and Senators Stafford (R-Vt.) and Weicker (R-Conn.) in 1987-89; nine Democrats and Senators Durenberger (R-Minn.) and Jeffords (R-Vt.) in 1989-91). See THE ALMANAC OF AMERICAN Politics 1988, supra note 65, for lists of Senators, committee memberships, and ADA scores for committee members.

132. 465 U.S. 555 (1984). 
assistance."133 Grove City College accepted no direct federal assistance, but its students received federal financial aid. A begrudging, albeit unanimous, Supreme Court ${ }^{134}$ held that even indirect financial assistance brought the college within the coverage of title IX, but by a six-to-two vote it held that only Grove City's financial aid department (and not other departments) fell withm the statute's "program or activity" language. ${ }^{135}$ The dissenting Justices argued that this interpretation of "program or activity" was inconsistent with the assumptions Congress made when it passed the amendments in $1972 .^{136}$

The dissenters' view was widely held in Congress. Within a month and a half of the decision, bills to override Grove City had been introduced in Congress, with dozens of members eager to cosponsor. ${ }^{137}$ If rhetoric is any gauge, the level of congressional outrage was at its highest since Gilbert. ${ }^{138}$ One member exclaimed:

It is sort of shocking that the Supreme Court of the United States has to get this kind of a lesson in 1984. This is not unsettled law. As a matter of fact, they are going against their own decisions. It leaves me slightly amazed that on a matter of this rather elementary nature in civil rights law that we're forced to come back to the ramparts one more time. ${ }^{139}$

Many of the key legislative players involved in creating title IX were still in Congress. They readily came forward to denounce the Court's conclusions about the original legislative intent. ${ }^{140}$

On May 23, less than three months after the Grove City decision,

133. Pub. L. No. 92-318, 86 Stat. 373 (codified as amended at 20 U.S.C. § 1681(a) (1988)).

134. Justice Powell (a Nixon appointee) wrote a separate opinion, in which Chief Justice Burger (a Nixon appointee) and Justice O'Connor (a Reagan appointee) joined, to express the view that "the case is an unedifying example of overzealousness on the part of the Federal Government." Grove City, 465 U.S. at 576.

135. Justice Stevens refused to join the Court's holding on this point but did not express a vicw on the merits. Id. at 579-81 (Stevens, J., concurring in part and dissenting in part). The only dissenters were Justices Brennan and Marshall, the remnants of the Warren Court's liberal majority. Id. at 581-604 (Brennan, J., concurring in part and dissenting in part).

136. Id. at 581-604 (Brennan, J., concurring in part and dissenting in part).

137. H.R. 5490, 98th Cong., 2d Sess. (1984) (introduced on April 12 by Rep. Simon, together with 71 cosponsors, which increased to 129 cosponsors when hearings began in May 1984); S. 2568, 98th Cong., 2d Sess. (1984) (introduced on April 12 by Sen. Kennedy).

138. See supra text accompanying notes 86-100.

139. Civil Rights Act of 1984: Joint Hearings Before the House Comm. on Education and Labor and the Subcomm. on Civil and Constitutional Rights of the House Comm. on the Judiciary, 98th Cong., 2d Sess. 36 (1984) (statement of Rep. Conyers (D-Mich.), who was an original supporter of title IX); see also id. at 13 (statement of Rep. Simon) ("In Grove City the Supreme Court ignored the congressional intent and rejected a long history of broad executive branch enforcement of Title IX of the 1972 Education Amendments. We must correct this result."); id. (statement of Rep. Sensenbrenner (R-Wis.)) (Court's decision "does not enunciate the intent of Congress when title IX was passed almost 10 years ago").

140. See id. at 40-53 (statement of Sen. Bayh, whom the Grove City Court had acknowledged as the key player for title IX (Grove City, 465 U.S. at 567)); id. at 55-56 (statement of Sen. Javits (RN.Y.), the key player on the Republican side). 
relevant House committees reported a broad override bill. The day before, the President had publicly indicated a willingness to veto the bill. ${ }^{141}$ During extensive hearings, the administration was virtually the only force opposing the override. ${ }^{142}$ The House passed the bill on June 26 by an overwhelming nrargin (375 to 32) ${ }^{143}$ Because the Senate bill had been bottled up in its committee by Senator Hatch (R-Utah), the House bill becanie the inechanism by which the Senate considered overriding Grove City. Pressured by the admmistration and Hatch, the Republican leadership refused to bring up the bill for consideration unless a compromise were worked out, and coniproinise negotiations occupied the remainder of the summer. At the end of Septeinber, the bill's supporters (there were by then 63 sponsors) forced the Senate to consider it. But Senator Hatch and the bill's other opponents vexed the bill with so niany killer aniendnient proposals that the bill's supporters ultinately agreed to table it..$^{144}$

The next Congress minrediately took up the Grove City issue. Again, Senator Hatch's committee buried the Senate bill, while the relevant House committees reported a strong Grove City bill. ${ }^{145}$ The bill, however, never canie up for a vote in the House. It ran into difficulties when the U.S. Catholic Conference expressed strong opposition, claiming that the bill would have the practical effect of forcing Cathohic hospitals to perforn abortions and schools to fund student abortions. One House committee accepted the Catholic Conference's position. But the bill's supporters were unwilling to compromise the right to abortion, and negotiations continued through the sunimer and fall without result.

When Congress next reconvened, Democrats controlled both the House and Senate. The Senate acted first, with 56 Senators sponsoring its Grove City bill. ${ }^{146}$ The Senate bill received expedited hearings in a conmittee no longer chaired by Senator Hatch. The Senate committee

141. 1984 CoNG. Q. ALMANAC 240.

142. H.R. ReP. No. 829, 98th Cong., 2d Sess. pts. 1 \& 2 (1984).

143. 130 CONG. ReC. $18,761,18,817$ (1984).

144. This was procedurally complicated. On September 20, sponsoring Senators Kennedy and Packwood (R-Ore.) announced that talks with the Administration had broken down. On September 27, Senator Byrd (D-W.Va.) introduced the bill as an amendment to the fiscal 1985 continuing appropriations resolution, H.R.J. Res. 648, 98th Cong., 2d Sess. (1984). The presiding officer sustained the Republican majority leadership's objection that the amendment was out-of-order, but the full Senate overruled the officer (51 to 48). 130 CoNG. REC. 27,452, 27,487 (1984).

A blur of further amendments followed, including a Hatch amendment to restrict federal judges' authority to order school busing, but the Senate invoked cloture on September 29. 130 Cong. Rec. 27,826 (1984). Despite cloture, the Senate was now-at the end of the session in a presidential election year-faced with voting on a number of controversial amendments, and on whether some of them (such as the busing amendment) were in order. Because of these circumstances, the Republican sponsors agreed to kill the bill for that Congress.

145. See H.R. REP. No. 963, 99th Cong., 1st Sess., pts. 1 \& 2 (1985).

146. S. 557, 100th Cong., Ist Sess., 133 CoNG. REC. S2249-56 (daily ed. Feb. 19, 1987). 
reported the bill on June 5, 1987. ${ }^{147}$ The Senate committee report argued that Congress had originally intended for title IX and related statutes to have institution-wide coverage. It maintained that executive implementation and interpretation of those statutes was premised upon that understanding, as were judicial interpretations prior to Grove City. "The purpose of the Civil Rights Restoration Act of 1987 is to reaffirm preGrove City College judicial and executive branch interpretations and enforcement practices which provided for broad coverage of the antidiscrimination provisions of these civil rights statutes."148 The report stated that Grove City misconstrued congressional intent and created absurd results.

Despite the committee report's strong wording, a Senate preoccupied with the Bork confirmation hearings did not get to the bill in 1987. In January 1988, the Senate passed the bill ${ }^{149}$ after accepting an amendment that restricted some protections for women seeking abortions; the House followed im March. ${ }^{150}$ President Reagan vetoed the bill on March 16 , argumg that it would unnecessarily expand the federal government's power at the expense of religious and other private freedoms. Within a week, both chambers of Congress overrode the veto by lopsided margins. ${ }^{151}$

\section{Older Workers Benefit Protection Act of 1990}

When the Court's McMann decision was being debated in Congress in 1978, the committee report and Senator Javits disapproved of the Court's reasoning as well as result. However, the actual statute that overruled McMann only added a proviso to protect against involuntary retirement. As a consequence, employee plans that were not a "subterfuge" to evade the statute were still exempt. Debate over this exemption returned to the Court in Public Employees Retirement System of Ohio v. Betts. ${ }^{152}$ The case involved a denial of disability benefits because of age-a situation which on its face seemed to violate the Act. Relying in part on the McMann understanding of subterfuge, the Court by a sevento-two vote upheld the discriminatory disability plan. ${ }^{153}$ This immedi-

147. S. REP. No. 64, 100th Cong., 1st Sess. (1987) (vote to report was 12-4), reprinted in 1988 U.S. CODE CONG. \& ADMIN. NEws 3. This report contains an excellent summary of the history of the Senate's attempts to override Grove City from 1984 to 1987.

148. Id. at 2, reprinted in 1988 U.S. CODE CoNG. \& ADMIN. News 4.

149. 134 CONG. REC. S266 (daily ed. Jan. 28, 1988).

150. 134 CoNG. REC. H597-98 (daily ed. Mar. 2, 1988).

151. 134 CoNG. Rec. S2765 (daily ed. Mar. 22, 1988) (vote of 73-24); 134 Cong. Rec. H107172 (daily ed. Mar. 22, 1988) (vote of 292-133).

152. 109 S. Ct. 2854 (1989).

153. See id. at 2861 ("As Congress did not amend the relevant statutory language, we see no reason to depart from our holding in McMann that the term 'subterfuge' is to be given its ordinary meaning ...."). 
ately reinvigorated the McMann understanding of "subterfuge," which had been attacked as a misinterpretation of legislative intent by the very legislators responsible for the ADEA's passage in 1978. The Court held that under the statute's "plain ineaning," the plan at issue was not a subterfuge and, hence, was exeinpt from the statutory prohibition. ${ }^{154}$ The Court rejected, as inconsistent with the statute's plain ineaning, the Departinent of Labor's "equal benefit or equal cost" regulations that had been endorsed by the key players in $1978 .{ }^{155}$

Betts shocked inost people who followed post-1978 ADEA developinents, because it was widely assumed that the congressional override of McMann had cemented the equal benefit or equal cost rule into the statute. Within two months of the Betts decision, bills were introduced in both the House and Senate to override Betts. ${ }^{156}$ These bills stated on their face: "The Congress finds that, as a result of the decision of the Supreine Court in [Betts], legislative action is necessary to restore the original congressional imtent $\mathrm{m}$ passing and amending the [ADEA]." 157 The bill's sponsors barely concealed their distrust of the Court: "In Betts, the Supreme Court once agam showed its disdain for civil rights by reaching the completely unexpected conclusion that einployers are free to engage in age-based discrimination against their einployees in the area of einployee benefits." 158

The report of the Senate Committee on Labor and Human Resources also sharply criticized the Supreme Court's "erroneous" interpretation not once, but twice:

The Committee regrets that the Supreme Court in Betts chose not to credit the language of the 1978 Conference Report, language that appeared in the Congressional Record and was overwhelmingly approved by both Houses of Congress. The Committee hopes that in the future, the Supreme Court will take inore seriously such expressions of legislative intent, particularly when they are subject to the same review and ratification as the language of the statute. ${ }^{159}$

The report also defended a retroactive overruling of Betts. ${ }^{160}$

154. See id. at $2863-64$.

155. See id. at 2862 ("The requirement that employers show a cost-based justification for agerelated reductions in benefits appears nowhere in the statute itself.").

156. H.R. 3200, 101st Cong., 1st Sess. (1989); S. 1511, 101st Cong., 2d Sess. (1990).

157. H.R. 3200, 101st Cong., 1st Sess. § 2 (1989); S. 1511, 101st Cong., 2d Sess. \$ 101 (1990).

158. 135 CoNG. REC. S9949 (daily ed. Aug. 3, 1989) (statement of Sen. Pryor (D-Ark.), sponsor of S. 1511); see also id. at S9949-50 (statement of Sen. Metzenbaum (D-Ohio)) (commenting that in a "stunning" decision, Supreme Court "reverses 20 years of the settled law," and castigating "the tortured logic and cruel result of the Supreme Court decision"); id. at S9950 (statement of Sen. Jeffords (R-Vt.)) ("I am personally convinced that the Congress which enacted the ADEA had no intention of broadly exempting from coverage so integral a portion of the employment relationship as employee benefits.").

159. S. REP. No. 263, 101st Cong., 2d Sess. 29 (1990).

160. See id. at 30-31. 
The committee bill's strong expression of disapproval met resistance in the Senate. Through the summer, Senators from both parties negotiated a broadly acceptable compromise bill. The compromise adjusted the bill's substantive provisions and largely removed its retroactivity provisions but retained the textual provision overruling Betts by name. ${ }^{161}$ The Senate and the House passed the override bill by overwhelining margins in late September and early October. ${ }^{162}$

\section{The Proposed Civil Rights Act of 1990}

The Court decided Patterson, Wards Cove, Martin v. Wilks, Hopkins, Zipes, and Lorance at the end of the 1988 Term, about the same timie as Betts. ${ }^{163}$ All six decisions had miplications for title VII. During the summer of 1989, civil rights groups in Washington drafted legislation to overrule all the decisions. They coordinated their efforts with the Senate Democrats, especially Senators Kemiedy (D-Mass.) and Metzenbaum (D-Ohio). Because of the number of decisions to be overruled and the complexity of the pohtical and constitutional issues, negotiations over the terms of the draft continued through the autumn and winter. Finally, on February 7, 1990, Senator Kennedy and thirty-three cosponsors introduced a bill to overrule these six decisions, as well as three earhier Supreme Court cases having similar implications for title VII. ${ }^{164}$ The same bill was introduced in the House by Representative Hawkins (D-Cal.) and many cosponsors. ${ }^{165}$

The bill's language and content indicated Congress' wholehearted rejection of the Court's decisions. The bill announced that "in a series of recent decisions addressing employment discrimination claims under Federal law, the Supreme Court cut back dramatically on the scope and effectiveness of civil rights protections."166 It added that the bill was designed "to respond to the Supreme Court's recent decisions by restoring the civil rights protections that were dramatically limited by those decisions." 167 The substantive sections of the bill then amended title VII or section 1981 to override one or more of the offending Supreme Court

161. See S. 1511,101 st Cong., 2d Sess. $\$ 101,136$ Cong. REc. S13,611 (daily ed. Sept. 24, 1990).

162. See 136 CoNG. Rec. S13,611 (daily ed. Sept. 24, 1990) (Senate vote 94-1); 136 CoNG. REc. H8738 (daily ed. Oct. 3, 1990) (House vote 406-17).

163. See supra notes 3-13 and accompanying text.

164. S. 2104, 101st Cong., 2d Sess., 136 CoNG. Rec. S1018-21 (daily ed. Feb. 7, 1990). The other three cases were: Crawford Fitting Co. v. J.T. Gibbons, Inc., 482 U.S. 437 (1987), Evans v. Jeff D., 475 U.S. 717 (1986), and Library of Congress v. Shaw, 478 U.S. 310 (1985).

165. H.R. 4000, 101st Cong., 2d Sess., 136 Cong. Rec. H364 (daily ed. Feb. 7, 1990).

166. S. 2104, 101st Cong., 2d Sess. $\$ 2(a)(1), 136$ CoNG. Rec. S1019 (daily ed. Feb. 7, 1990).

167. S. 2104, 101st Cong., 2d Sess. $\$ 2(a)(1),(b)(1), 136$ CoNG. REc. S1019 (daily ed. Feb. 7, 1990). 
cases. ${ }^{168}$ With complex transition rules, the bill overruled most of the nine Supreme Court cases retroactively. ${ }^{169}$ The sponsors of the bill roundly indicted the Supreme Court's performance in the 1988 Term. "I believe the Supreme Court's recent rulings represent an effort to renege on history," said Senator Jeffords (R-Vt.). ${ }^{170}$

At hearings on the bills in the House and Senate during February and March, the administration agreed that Patterson and Lorance should be overruled, but strongly opposed overruling Wards Cove and Martin $v$. Wilks. ${ }^{171}$ The administration's position, eloquently articulated by Senator Hatch, was that the provision overriding Wards Cove would all but coinpel employers to adopt quotas by making title VII liability hinge on bad numbers. ${ }^{172}$ Hatch later, during the floor debates, further argued that the provision overriding Martin v. Wilks was unfair to white males penalized by old consent decrees and, in fact, raised due process problens. ${ }^{173}$ The administration and the business community were also concerned about the bill's creation of new compensatory and pumitive damages remedies for violations of title VII. Attorney General Thornburgh explored these and other concerns in detail in a letter to Senator Kennedy, imdicating that he would urge the President to veto the bill in anything like its current form. ${ }^{174}$

In negotiations that spring, Senate Deinocrats, moderate Senate

168. Section 4 overruled Wards Cove and set standards for proof of unlawful employment practices in disparate impact cases. Section 5 overruled Hopkins by stipulating that a discriminatory practice need not be the sole motivating factor to make out a violation of the statute. Section 6 replaced Martin v. Wilks with guidelines for assuring finality of consent decrees. Section 7 amended existing provisions of titie VII to overrule Lorance. Section 9 inciuded a series of teclinical proeedural amendments to title VII to overrule Zipes, Crawford, and Jeff D. Section 10 provided for interest against the United States, overruling Shaw. Section 12 amended section 1981 to overrule Patterson.

169. Section 15(a) provided that most of the substantive provisions would be retroactively applicable, beginning on the dates the Court had handed down the relevant decisions.

170. 136 CONG. REC. S1022 (daily ed. Feb. 7, 1990); see also id. at S1018 (statement of Sen. Kennedy) ("In the past year . . . the Supreme Court lias issued a series of rulings that mark an abrupt and unfortunate departure from its historic vigilance in protecting civil rights. The fabric of justice lias becn torn.").

171. Civil Rights Act of 1990: Hearing on S. 2104 Before the Senate Comm. on Labor and Human Resources, 101st Cong., 2d Sess. 111 (1990) [hereinafter 1990 Senate Civil Rights Hearings]; Civil Rights Act of 1990: Joint Hearings on H.R. 4000 Before the House Comm. on Education and Labor and the Subcomm on Civil and Constitutional Rights of the House Comm. on the Judiciary, 101 st Cong., 2d Sess. 358-62 (1990). The administration's override bill was introduced on February 22 by Senator Hatcl in S. 2166, 101st Cong., 2 d Sess. (1990). See 136 Cong. REc S1522 (daily ed. Feb. 22, 1990).

172. 1990 Senate Civil Rights Hearings, supra note 171, at 5 (stating that the bill "so dramatically change[s] title VII that the only way to aviod being sued is to hire solely by numbers, to use quotas for hiring and promotion").

173. 136 CONG. REC. \$9830-31 (daily ed. July 17, 1990).

174. Letter from Attorney General Richard Thoruburgh to Senator Edward Kennedy (Apr. 3, 1990). 
Republicans, and the White House sought to resolve these problems. The Wards Cove/Griggs issue of how to express the proof required to establish and defend against disparate impact cases posed the biggest hurdle. Hoping to reach a compromise with the administration, the Senate twice postponed consideration of the bill. With the same purpose, the Democratic and Republican supporters offered several amended bills. ${ }^{175}$ On July 12, it appeared that the Delnocrats and the administration had reached agreement on the key provision (a definition of "business necessity"). ${ }^{176}$ However, the deal immediately unraveled, possibly because of cold feet in the administration. ${ }^{177}$ The negotiations continued.

The Senate voted for cloture of debate on July $17,{ }^{178}$ over the bitter objections of the Republican leadership and despite bipartisan irritation over the lengtliy impasse with the administration. After the cloture vote, the White House urged continuation of the negotiations. ${ }^{179}$ Negotiations continued, and yet anotlier Kennedy-Jeffords substitute was offered up. The negotiations lasted into the final day of the Senate's consideration of the bill, ${ }^{180}$ when, at the eleventh hour, they collapsed over the quota issue. ("Quotas shmotas," grumbled Senator Kennedy.) ${ }^{181}$ The Senate passed the second Kennedy-Jeffords substitute by a vote of 65 to $34 .{ }^{182}$ The House passed a similar bill on August 3, by a vote of 272 to $154 .{ }^{183}$

As is often the case, negotiations over the bill's content continued almost without interruption after passage by both chambers and during the conference cominittee process. One conference report was submitted to Congress on September 26. ${ }^{184}$ The House voted to recominit so that the conferees could add further language to appease the President. ${ }^{185} \mathrm{~A}$

175. The Kennedy-Danforth amended version of S. 2104 that emerged from committee was to be superseded by a Kennedy-Jeffords substitute. See 136 CoNG. REC. S9325-27 (daily ed. July 10, 1990). A Kassebaum-Gorton compromise proposal also appeared, see 136 CoNG. REC. S9756 (daily ed. July 16, 1990), but was then withdrawn.

176. See 136 CoNG. REc. S9824-25 (daily ed. July 17, 1990) (statement of Sen. Danforth describing the oral agreement and its mysterious unraveling); id. at \$9829-30 (statement of Sen. Kennedy describing the apparent deal and the apparent impasse that nonetheless developed).

177. See Holmes, Accord Is Sought on Rights Measure to Avert a Veto, N.Y. Times, July 20, 1990, at A1, col. 6.

178. 136 CoNG. REC. S9823 (daily ed. July 17, 1990) (vote of 62-38, including 8 Republicans voting for cloture).

179. Id. at $\mathbf{S} 9836$ (statement of Sen. Danforth).

180. 136 CONG. REC. S9918-19, S9934 (daily ed. July 18, 1990).

181. Id. at $\$ 9947$.

182. Id. at $\mathrm{S} 9966$.

183. 136 Cong. Rec. H6769 (daily ed. Aug. 3, 1990). The key moves during the House deliberation were the party-line vote to adopt a modified closed rule restricting amendments on the bill, see 136 CoNG. REC. H6336 (daily ed. Aug. 2, 1990), and the defeat of a Republican substitute by a party-line 238-188 vote, see 136 CoNG. Rec. H6768 (daily ed. Aug. 3, 1990).

184. H.R. Conf. Rep. No. 755, 101st Cong., 2d Sess., reprinted in 136 CoNG. REc. H8045-50 (daily ed. Sept. 26, 1990).

185. 136 CoNG. Rec. H9405-06 (daily ed. Oct. 11, 1990) (recommittal motion vote of 375-45). 
second conference report was submitted on October $12 .{ }^{186}$ The final conference bill made a number of changes in the Wards Cove provision in an attempt to gain White House support. These changes mcluded a more liberal definition of the business necessity defense in disparate impact cases, statutory language discouraging employers from adopting quotas, confirmation that bad numbers alone do not violate title VII, and a requirement that plaintiffs prove which employer practices cause the disparate impact. ${ }^{187}$

By October, the White House position seerned more conservative than it had been in July, and the President seemed ready to veto the bill despite all concessions. ${ }^{188}$ Nonetheless, both chambers adopted the conference bill by lopsided, but not veto-proof, margins. ${ }^{189}$ On October 20, the President sent Congress his own civil rights bill, which would have overruled or modified most of the cases that Congress sought to overrule (but in different ways, of course). It was iguored by Congress. Two days later the President vetoed Congress' bill, ${ }^{190}$ and the Senate failed by one vote to override the veto. ${ }^{191}$

\section{II}

\section{Positive Game Theory Analysis of Congressional RESPONSES TO THE SUPREME COURT'S INTERPRETATION OF CIVIL RIGHTS STATUTES}

The story told in Part I demonstrates in a general but fairly concrete way that civil rights statutory policy is dynamic and interactive. Civil rights policy is interactive because it involves the cooperation, and often the conflict, among the Congress (which enacts the statutes), the President (who has veto power and influences the statute's implementation), and the Court (which presides over the statute's interpretation). Civil rights policy is also dynamic. For one thing, the actual mix of stat-

186. H.R. CONF. Rep. No. 856, 101st Cong., 2d Sess., reprinted in 136 CoNG. ReC. H9552-59 (daily ed. Oct. 12, 1990).

187. 136 CoNG. REC. $S 15,327$ (daily ed. Oct 16, 1990) (statement of Sen. Kennedy). These changes were made in response to negotiations among Senator Hatch, Senator Specter, and former Secretary of Transportation William Coleman. Id. at S15,328 (statement of Sen. Hatch).

188. See id. at \$15341-42 (statement of Sen. Jeffords); Letter from Attorney General Richard Thornburgh to Senator Robert Dole (Oct. 12, 1990), reprinted in 136 CoNG. Rec. S15,328-29 (daily ed. Oct. 16, 1990). Apparently, Senator Hatch would have been willing to support the conference bill if the White House had acquiesced. See 136 CoNG. REc. S15,328 (daily ed. Oct. 16, 1990) (statement of Sen. Hatch); id. at $\$ 15,332$ (statement of Sen. Specter).

189. Id. at $\$ 15,407$ (Senate vote, 62-34); 136 CoNG. REc. H9994-95 (daily ed. Oct. 17, 1990) (House vote, 273-154).

190. 136 CoNG. REC. $\$ 16,562-63$ (daily ed. Oct. 24,1990 ) (reprinting the veto message).

191. At 11:50 p.m. on October 24, 1990, the Senate voted by 66 to 34 to override the veto. Fifty-five Democrats and eleven Republicans voted to override. 136 CoNG. REC. S16,589 (daily ed. Oct. 24, 1990). 
utes changes constantly as Congress enacts new statutes. In addition, the interpretation and impleinentation by the President and the Court strongly affect the evolution of each statute and the way the statutes knit together over time. Therefore, the dramatic changes in the attitudes of the President and of the Court (and, to a lesser extent, of Congress) toward these statutes have significantly affected the statutory policy.

Part I inakes traditional political theory assumptions (such as the importance of interest groups and committees), but is otherwise atheoretic. Part II borrows from positive political theory a model of Congress/agency interaction and uses it to construct a theoretical framework for thinking about the Congress/Court/President interaction over time. This model does not perfectly explain the data, and I then suggest a modified model that does. As modified, this political theory framework suggests some interesting twists on the history outhined in Part I and some directions for future interaction. It indicates that the Court/ Congress conflict will continue into the 1990s (though it is not clear at what level of intensity). Perhaps surprisingly, it suggests that the main variable in the Court/Congress balance will be the political preferences of the Presidency.

\section{A. A Game Theoretic Analysis of Supreme Court Policymaking in Civil Rights Statutes}

For some time now, positive pohtical theory has been developing game theoretical models of the legislative process. Much of the theory has focused on legislator incentives and, specifically, the operation of a legislature in which members are primarily motivated by a desire to be reelected. ${ }^{192}$ Recently, positive political theory has explored issues arising from the legislature's interaction with agencies and the President. ${ }^{193}$ Scholars, inost notably John Ferejohn, have been developing a model of Congress/agency interaction to explam Congress' ability to influence agency decisionmaking over tiine, even when it does not enact statutes

192. See B. Cain, J. Ferejohn \& M. Fiorina, The Personal Vote: Constituency SERVice AND Electoral INDEPENDENCE (1987); M. Fiorina, Congress: Keystone of THE WASHINGTON Establishment (1977); D. MAYHEW, CONGRESS: THE ElECTORAL CONNECTION (1974). For a more public-regarding view of legislator motivations, see R. FENNO, CONGRESSMEN IN COMMITTEES (1973); K. KREHBIEL, INFORMATION AND LEgISLATIVE ORgANIZATION (1991); A. MaAss, Congress and the Common Good (1983).

193. See Ferejohn \& Shipan, Congressional Influence on Administrative Agencies: A Case Study of Telecommunications Policy, in Congress Reconsidered 393 (L. Dodd \& B. Oppenheimer 4th ed. 1989); Mathews, Veto Threats: Rhetoric in a Bargaining Game, 104 Q.J. EcoN. 347 (1989); Moe, An Assessment of the Positive Theory of Congressional Dominance, 12 LEGIS. STUD. Q. 475 (1987); Weingast \& Moran, Bureaucratic Discretion or Congressional Control? Regulatory Policymaking by the Federal Trade Commission, 91 J. PoL. EcoN. 756 (1983). 
that overrule the agency directly. ${ }^{194}$ Their model, the positive political theory model, might be apphied to understand legislative control of judicial statutory interpretation as well. ${ }^{195}$

The Court/Congress/President game, which follows froin this model, is relatively straightforward. It is played out on a one-dimensional linear field that starts with the optimal political preferences of the major players, charting those preferences froin left/liberal to right/conservative (liere, the preferences concern civil riglits legislation). I start with the assumptions of the positive political theorists who developed the outlines of my Court/Congress/President game: The political players are the Supreme Court $(C)$, which interprets existing civil rights statutes; the legislative gatekeepers (G), which substantially control Congress' agenda and which I consider to be the committees with jurisdiction over civil rights bills plus the inajority party leadership; ${ }^{196}$ the Congress, which lias the power to overrule the Court and is treated here as a single chamber whose preferences are represented by those of its median inember (hence the notation $M$ ); ${ }^{197}$ and the President $(\mathrm{P})$, who has the power to veto legislation.

The game is played in the following sequence. The Court inakes the first move when it interprets a civil rights statute. Once tle Court has

194. See Ferejohn \& Shipan, Congressional Influence on Bureaucracy, J.L. EcoN. \& ORGANIZATION (1990).

195. The most notable paper is B. Marks, A Model of Judicial Influence on Congressional Policymaking: Grove City College v. Bell (May 1989) (Ph.D. dissertation, Washington University) (on file with author). See also J. Ferejohn \& B. Weingast, Limitation of Statutes: A Strategic Theory of Interpretation (prepared for delivery at the Conference on Constitutional Law and Economics, Stanford Law School (Oct. 25-26, 1990)) (on file with author).

196. This is a departure from traditional positive political theory, which assumes a single gatekeeping committee. In both the House and Senate, there are two committees with potential jurisdiction over antidiscrimination legislation-the judiciary committee and the labor committee. The existence of the two committees in each chamber itself makes the assignment power (by the House Speaker and the Senate Majority Leader) significant, but in both chambers the leadership exercises other powers as well. The House Rules Committee, since 1973 an arm of the leadership, can do much to dictate the terms of the debate by seeking closed or modified closed rules. (This is another departure from Ferejohn and Shipan, who assume that the House can always overrule a closed rule suggestion.) The Senate Majority Leader las weaker power in this regard but often affects the agenda by orchestrating or frustrating unanimous consent agreements, by deciding which bills to call up and in which order, and by seeuring desired rulings on points of procedure. For example, Majority Leader Baker's delaying tactics in the summer of 1984 were instrumental in killing the Grove City bill that year.

197. Using the preferences of the median legislator to indicate the legislative outcome is itself a "strong" assumption based on other assumptions such as a one-dimensional political spectrunn and the inability of legislative processes to aggregate intensity of preference. Nonetheless, the median voter rule is a powerful and well-established theoretical construct in the collective choice literature. Basically, it suggests that on a single left-right spectrum where only one outcome is possible and no vote trading is permitted, the favored position of the median voter will prevail. See A. DowNs, AN ECONOMIC THEORY OF DEMOCRACY 114-41 (1957); Bowen, The Interpretation of Voting in the Allocation of Economic Resources, in READINGS IN WELFARE EcONOMICS 115-32 (K. Arrow \& T. Scitovsky eds. 1969); Hotelling, Stability in Competition, 39 EcoN. J. $41-57$ (1929). 
interpreted the statute, the gatekeepers then decide whether they want to seek a legislative override; if they do, Congress must decide what policy to adopt, and it is not constrained by the gatekeepers' choice. If Congress passes a statute, the President must decide whether to veto it. Should the President veto it, Congress must decide whether to override the President's veto. This sequence of decisionmaking is mapped out in the diagram below:

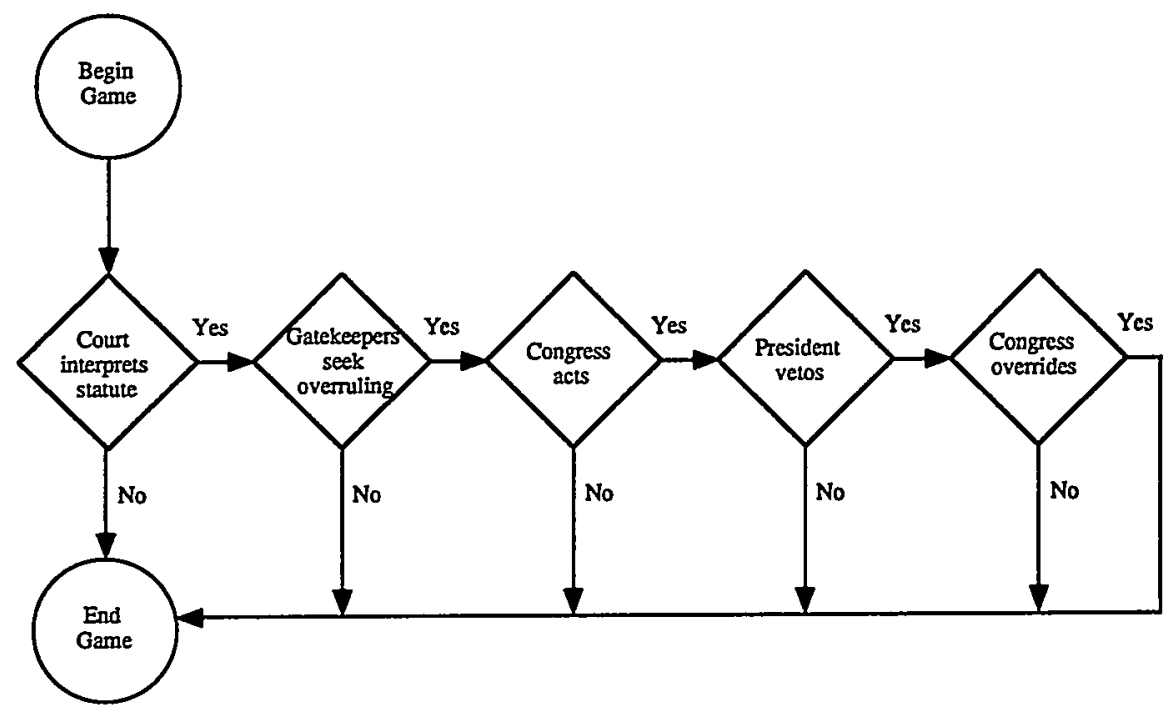

The Court/Congress/President game assumes that each player operates with complete information about other players' preferences, and, therefore, perfectly anticipates the future course of play. Moreover, each player in making its moves will not want to make a decision that will be overturned by another player with the authority to do so. In other words, in deciding whether to act, each player will do nothing if it realizes that its decision will be overturned by the next player.

The game's sequential nature, the players' possession of perfect information, and their reluctance to be overruled make two other preference points important. One is a player's "indifference point," the point on the spectrum that the player likes just as much as another point in the opposite direction (the player is indifferent as to the two points). For example, in our civil rights game, the gatekeepers' preferences (G) are usually to the left of those of the median member (M). The gatekeepers' indifference point $(\mathrm{G}(\mathrm{M}))$ is the point to the left of their preferred point that they hike just as much as they like M, but in the other direction. ${ }^{198}$

198. Or stated more formally: If the gatekeepers' preferences were to the left of the median legislator's, and the intensity of the gatekeepers' preferences were single-peaked, then there would be 
Indifference points are important to the gatekeepers, because they will not seek an overruling of a Supreme Court decision if it is between the legislative median and the gatekeepers' indifference point $(\mathrm{G}(\mathrm{M})<\mathrm{C}<$ $M)$. Knowing they will be overruled by Congress if they introduce a bill setting their preferences ( $G$ loses to $M$ ), the gatekeepers will simply not introduce override legislation.

According to the assumptions of the game's designers, the President only becomes involved when the gatekeepers seek an override and Congress responds with override legislation. When a President is faced with a decision of whether to veto the legislation, another salient point arises in our game, namely, the veto median (V). The veto median is the point that divides both legislative chambers so that a third of the menbers have ideal points to the right of $\mathrm{V}$ and two-thirds have ideal points to the left, or vice versa. $V$ is obviously a strategic point of reference for a President who does not wish to have his veto overridden. Also, since $V$ will he to one side of the preferences of the median legislator, it has the

a point to the left of $G$ that the gatekeepers like just as much as they like the position of the median legislator. This is their indifference point and is represented as $G(M)$. This is demonstrated graphically below.

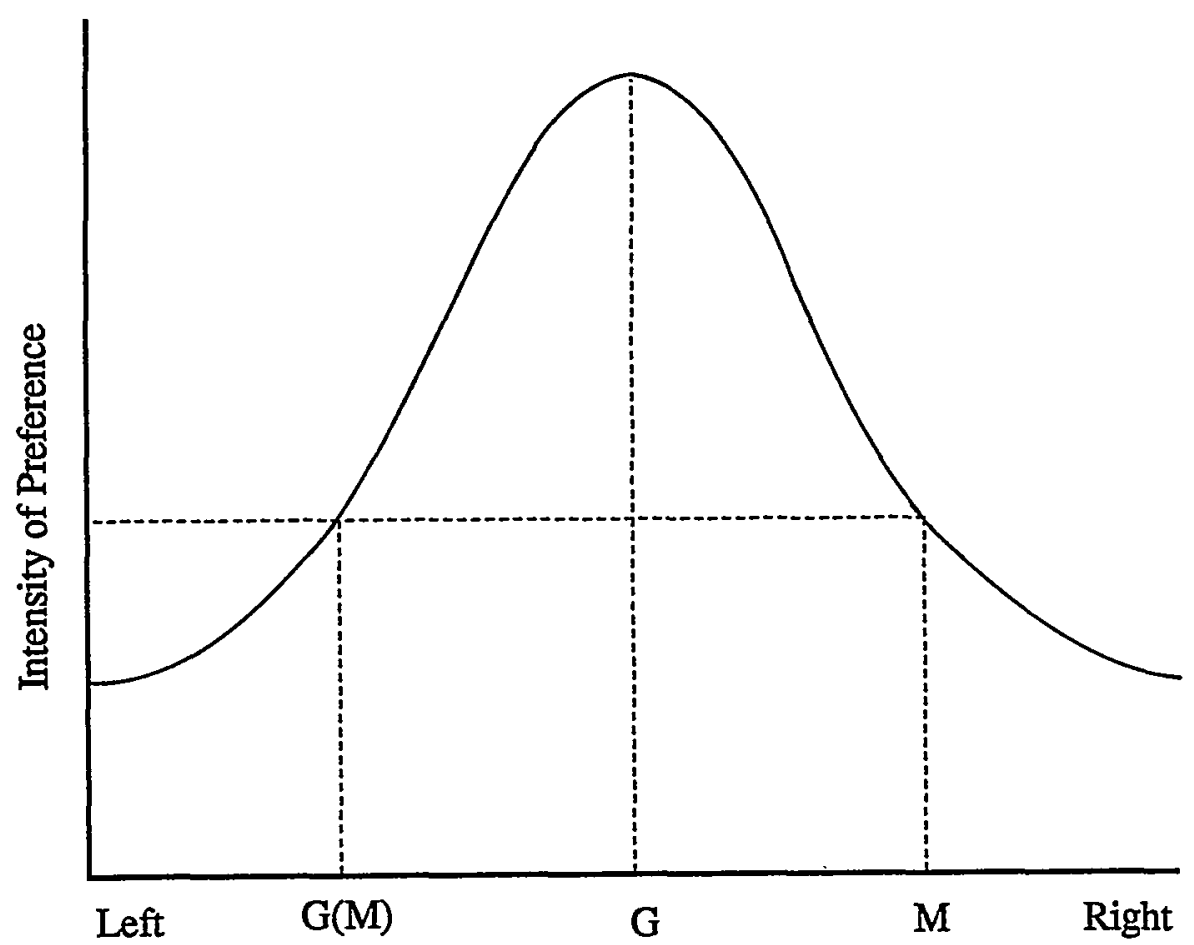

Political spectrum 
potential of increasing the range within which a Court decision could be protected from overruling legislation.

Despite its "strong" assumptions, the positive game provides a robust explanation for the behavior of the Court, Congress, and the President in three periods roughly tracking those described in Part I. The explanation, however, is not perfect. In this Part II(A), I identify data that the positive game does not explam. Later, I introduce a variation on the model that corrects those flaws.

\section{Court/Congress/President Cooperation: 1962-72}

Recall that in the first period we identified, 1962-70, the preferences of the Court and the President apparently were to the left of Congress' preferences, and the preferences of the gatekeepers in Congress were somewhat to the left of Congress' preferences. ${ }^{199}$ Figure 1 maps these relationships linearly. ${ }^{200}$ Using these relationships as our starting point, consider how the Court/Congress/President game plays out.

Figure 1

Civil Rights Preferences, 1962-71

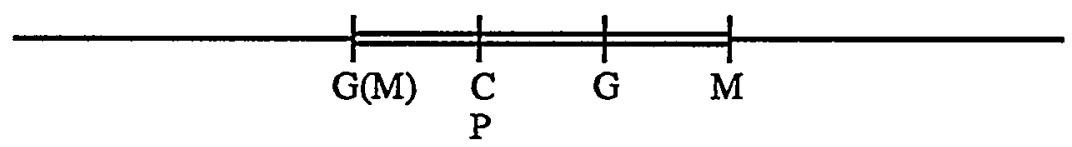

For purposes of this Figure, recall the abbreviations we are using:

$\mathrm{C}=$ Majority of Supreme Court

$\mathrm{G}=$ Gatekeepers (relevant committees \& majority leadership)

$\mathrm{M}=$ Median Member of Congress

$\mathbf{P}=$ President

$\mathrm{G}(\mathrm{M})=$ Gatekeepers' Indifference Point

$\mathrm{V}=$ Veto Median

Given this array of preferences, one expects a short and simple game, in which the Court merely reads its preferences into civil rights statutes. This is our expectation, because the Court makes the first move

199. The House and Senate leadership-Speaker McCormack (D-Mass.) and Majority Leader Mansfield (D-Mont.) through most of this period-was decidedly in line with the preferences of Presidents Kennedy and Johnson and to the left of President Nixon's. The House Judiciary Committee (chaired by Representative Celler (D-N.Y.)) and Education and Labor Committee (chaired by Representative Perkins (D-Ky.)) were more liberal than the House median on both the Democratic and Republican sides. The same was not true of the Senate Judiciary Committee (chaired by Senator Eastland (D-Miss.)), which was to the right of the Senate median. The Senate Labor and Public Welfare Committee (although chaired by Senator Hill (D-Ala.) until 1969) was to the left of the Senate median. See supra notes $27 \& 25$.

200. With some alterations as to terminology, the figures in this Part are adapted from Ferejohn \& Shipan, supra note 194. 
and wants to interpret the statute as closely as possible to its own preferences (C) without being overruled by Congress. Figure 1 suggests that the Court can impose its own preferences in this manner, because the gatekeepers have no incentive to introduce override legislation. The gatekeepers have no incentive because if they did introduce override legislation to implement their preferences $(G)$, Congress would simply implement its own preferences $(M)$. Since the gatekeepers prefer the Court's result to Congress' $(\mathrm{G}(\mathrm{M})<\mathrm{C}<\mathrm{M})$, they will not introduce override legislation. ${ }^{201}$

As explained above, Figure 1 describes the players' preferences during this period. Consider how the game changes (shightly) if the Court's position falls to the left of the gatekeepers' indifference point (that is, $\mathrm{C}<\mathrm{G}(\mathrm{M})$ ). In that event, the Court would not want to implement its desired policy (C), because that would stimulate the gatekeepers to propose a statute overruling its decision (since the gatekeepers prefer the congressional median to the Court's decision). Any time the Court implements a policy to the left of $G(M)$, then Congress will simply respond by enactimg the overruling statute (at $x=M$ ). In such a situation, the Court's best strategy would be to compromise its own preferences and choose the gatekeepers' indifference point as its decision $(x=G(M))$. In short, so long as the Court's decision falls on or to the right of $G(M)$ (that is, $G(M)<C$ )-the point the gatekeepers like just as much or more than $\mathbf{M}$-the gatekeepers will not propose legislation. Without a proposal by the gatekeepers, Congress will have nothing to act upon. With no act from Congress, the President does not play in the game.

Hence, under Figure 1 and simple variations, the Court can make any decision $(x)$ im the interval $\{G(M), M\}$ and not be overruled by Congress. In general, the Court will choose as its decision either its preferred point or the gatekeepers' indifference point, whichever is further to the right $(x=\max \{C, G(M)\})$. Note that $I$ have drawn Figure 1 so that the Court's preferred point (C) is to the right of G(M). Thus, on issues for which this is the correct configuration, the Court will simply adopt its preferred point (C) as its final decision. I think this preferred point is where the Court actually was for most civil rights issues in the period 1962 to 1972 - to the left of Congress generally, and usually to the left of the gatekeepers as well, but not so far to the left that it provoked legislative overruling.

The game in Figure 1 predicts that the Court would be able to interpret civil rights statutes more liberally than Congress or even its gate-

201. For the simple game in Figure 1, we do not assign a major role to the President. But note that the President would not always be able to protect the Court through a veto in the situation described in Figure 1. 
keepers would have wanted during this period, without risking a legislative overruling so long as the Court's decision was not to the left of the gatekeepers' indifference point (G(M)). This gaine suggests a Court with a great deal of pohicy influence-a Court able to steer civil rights pohicy significantly to the left of what Congress desired. ${ }^{202}$ The gaine just described does in fact capture much of what occurred during the period of 1962 to 1972: The Court's decisions interpreting civil rights statutes were in soine cases to the left of decisions that Congress itself would have inade, yet Congress overruled none of thein, in part because the gatekeepers refused to iritiate overruling proposals.

The best exanple of the positive game in action involves Jones $v$. Mayer. Jones reinterpreted section 1982 to create a substantially inore hberal remedy for race discrimination in housing than Congress had been willing to create, just weeks before, in title VIII. ${ }^{203}$ The Court's decision probably represented a more hiberal remedy than that favored by the median Member of Congress. Nevertheless, there was no effort to overrule Jones v. Mayer. Indeed, there probably were no such proposals because the House gatekeepers-the Deinocratic Leadership and the Judiciary Committee-preferred the Court's decision to the compromise solution reached by Congress in title VIII. ${ }^{204}$

Following the Jones decision, lower federal courts began to apply its reasoning to section 1981 cases involving claims of einployment discrimination. ${ }^{205} \mathrm{Had}$ it been asked to decide if section 1981 applied in these instances, Congress probably would have balked, since section 1981 procedures and reinedies (including punitive damages) were quite liberal.

202. If we included the President in this gamc (as I do below for the last period, 1981-90), the Court's ability to move civil rights policy to the left would be even more pronounced. During most of the period 1962-72, the President was aligned with the Court and could be expected to veto any effort by Congress to overrule the Court. In such cases, the relevant preference becomes either the gatekeepers' indifference point (G(M)) or the veto inedian (V), whichever is further to the left. This would allow the Court to implement its own policy in some cases where $C<G(M)$.

203. Title VIII covered discrimination in transactions involving residential realty alone, while section 1982 as interpreted in Jones $v$. Mayer covered business and personal property as well. Title VIII was adininistratively enforced through a gradual phased-in process, but Jones $v$. Mayer immediately activated a private right of action. Title VIII contained a number of exeinptions in order to procure Republican support (for example, religious institutions, small boardinghouses), none of which pertained to newly interpreted section 1982.

204. The year after Jones v. Mayer, the House Judiciary Committee was chaired by the very liberal Enanuel Celler, who prided himself above all on his sponsorship of the Civil Rights Act of 1964. The Coinmittee consisted of 15 liberal Deinocrats, 5 southcrn Democrats, and 15 Republicans, of whom 5 were liberal castern Republicans and another 4 were midwestern moderate conservatives who strongly supported civil rights legislation. See 1969 Cong. Q. ALMANAC 66 (listing Committee membership). Celler, the chair of the Committee, would have stalled any bill to overrule Jones $v$. Mayer. Moreover, even if the bill could have gotten to a Committee vote, it would have only received between eleven and fifteen of the thirty-five votes on the Conmittee.

205. See C. Abernathy, Civil Rights: Cases and Materials $265-76$ (1980) (collecting cases). 
Indeed, they were much more hiberal than those Congress had adopted (as a compromise to end the Senate filibuster) im title VII. When it came time to reexamine title VII, the congressional gatekeepers refused to propose that the parallel section 1981 cause of action be curtailed or ehminated by title VII. However, amendments to overrule the section 1981 cases were made in both chambers. A majority of Senators present favored the Senate amendment, but it failed on a tie vote because of maneuvering by the Senate leadership. ${ }^{206}$ The House amendment was rejected in committee but adopted by a narrow vote on the House floor. ${ }^{207}$ The House conferees-members of the gatekeeping committee that had rejected the proposal-predictably abandoned it in conference. ${ }^{208}$

Following Jones v. Mayer, the gatekeepers in Congress were able to use their institutional position to protect judicial decisions expanding Jones - a result they preferred to the congressional overrides that would have otherwise occurred. This example illustrates the various opportunities gatekeepers have to head off overruling proposals. The Court/ Congress/President game explains this behavior fairly well. It also explains the gatekeepers' eagerness to write committee reports endorsing the Court's results in cases hike Allen and Griggs, which the gatekeepers (more hberal than the median member in this initial period) preferred over results that Congress would have provided.

What the Court/Congress/President game does not explain as well is Congress' willingness to codify decisions like United States v. Guest ${ }^{209}$ and Louisiana v. United States. ${ }^{210}$ These liberal decisions represented highly dynainic interpretations of the 1870 Act. Not only did Congress fail to overrule the decisions, but it also ultimately went along with the suggestion made by both the Court and the gatekeepers that new and more expansive statutes be enacted to protect civil rights workers and voting rights. The positive political theory model would suggest that in these circumstances, Congress must have agreed with those decisions $(C=M$, not $C<M)$. Although this scenario can neither be proved nor

206. The recorded vote was 33-33, which meant the defeat of the amendment. But there was a 34th Senator on the floor, Senator Gambrell (D-Ga.), who announced that he favored the amendment but was a "live pair" with an absent Senator opposed to the amendment. See 118 CoNG. REC. 3372-73 (1972). This was very unusual: a Senator will rarely be in a live pair when doing so would affect the outcome. Apparently the Democratic leadership had made some special deal with Senator Gambrell.

207. 117 CONG. REC. 32,111 (1971).

208. Of the 20 Representatives named to the conference by the House leaderslip, see 118 CoNG. REC. 5187 (1972), 11 (all but one of the Democrats) liad voted against the amendment, see 117 CONG. REC. 32111 (1971).

209. 383 U.S. 745 (1966).

210. 380 U.S. 145 (1965). 
disproved, I am doubtful that it represents the entire story. I present another explanation in Part II(B).

\section{Court/Congress Conflict: 1972-81}

Between 1971 and 1975, a dramatic change in institutional alignments occurred as the Court shifted to the right of Congress. For many issues, the shift yielded the configuration described in Figure 2.

Figure 2

Civil Rights Preferences, 1972-81

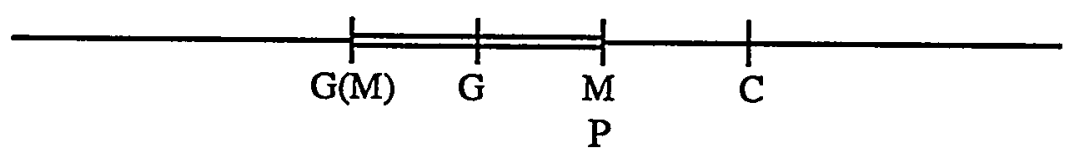

That is, the Court's preferences (C) were often to the right of the preferences of Congress (M), while the gatekeepers' preferences (G) remained slightly to the left of those of the median member. The President's preferences $(\mathrm{P})$ moved closer to the congressional median during this period but were often to the left of that median. ${ }^{211}$

The dynamics of the institutional interactions are simpler in this second period. Under this new configuration (Figure 2), if the Court implements its own preferences (C) through interpretation of the civil rights statutes, it will be overridden, because the gatekeepers will have an incentive to introduce overruling legislation (they prefer any $\mathrm{x}<\mathrm{C}$, and the ultimate result $M<C$ ), and Congress will vote for its preferred outcome over that of the Court (it prefers $\mathrm{M}$ to $\mathrm{C}$ ). As a result, the Court has a strong incentive to compromise its preferences and reach results that are at or to the left of the congressional median (M). Interestingly, because the Court's preferences are on the other side of the congressional inedian from the gatekeepers' preferences, the Court has lost much of its discretion to reach a result at variance with the median congressional preference $(M)$ and, as a consequence, the Court runs a much greater risk of being overruled.

This Court/Congress/President game captures nicely much of what went on in the 1970s. A good example is the Supreme Court's decision in Runyon v. McCrary. ${ }^{212}$ Runyon affirmed the application of Jones $v$. Mayer's interpretation of section 1982 (discrimination in property transactions) to section 1981 (contract transactions). The Court's willingness

211. The Presidents during the 1970 s held preferences not far from those of the median member. Because the Office of Civil Rights remained strongly to the left of $M$ during this period, the administrations were on the whole at $M$ or to the left of $M$ and were, therefore, of no consequence in the game. The story changes substantially in the 1980s, as Part II(A)(3) will reveal.

212. 427 U.S. 160 (1976). 
to extend the Jones reasoning here, by a seven-to-two vote, was exphicitly premised upon the Court's behef that Congress, in 1971-72, had approved of the application of Jones v. Mayer to section 1981 cases. $^{213}$ Moreover, two of the seven majority Justices wrote concurring opinions suggestimg that they thought Jones v. Mayer was in fact wrongly decided but that stare decisis, reinforced by current legislative policy, impelled them to go along with a liberal interpretation of section $1981 .^{214}$ A third Justice in the majority probably would have voted with the dissenters if the Court had split four-to-four. ${ }^{215}$ Runyon is the rare case in which the Court all but announces that it is voting against its preferences in order to accommodate the preferences of the current Congress.

A nuinber of other Burger Court decisions in the late 1970s relied on the Court's perception of legislative preferences to reach results that appeared inore liberal than the Court's own preferences. ${ }^{216}$ Indeed, the Court/Congress/President gaine provides an interesting explanation for United Steelworkers v. Weber, ${ }^{217}$ which interpreted title VII to allow voluntary affirmative action. Justice Stewart, who voted with the Weber inajority, had voted the year before against the constitutionality of voluntary state affirmative action. ${ }^{218}$ Anotler inajority Justice explained his vote in Weber as a response to societal developments that had overtaken the original congressional expectations. ${ }^{219}$ Both these Justices may have been sensitive to the pressures for affirmative action created by Griggs $v$.

213. Id. at 174-75 \& n.11. I argue that the Court was mistaken, in Eskridge, Interpreting Legislative Inaction, 87 MiCH. L. REV. 67 (1988).

214. See Runyon, 427 U.S. at 186-89 (Powell, J., concurring); id. at 189-92 (Stevens, J., concurring).

215. The third Justice was Chief Justice Burger, who held preferences to the right of Justice Stevens, and who was notorious for voting against his preferences so that he could assign the majority opinion.

216. For the most prominent examples, see Cannon v. University of Chicago, 441 U.S. 677, 68587, 694-708 (1979) (Court split 5-1-3, with the bare majority opinion resting on the apparent congressional assumption that title IX included a private cause of action); Monell v. Department of Social Servs., 436 U.S. 658, $691-701$ (1978) (7-2 split Court relies upon recent legislative assumptions in overruling line of section 1983 cases); Umited States v. Board of Comm'rs, 435 U.S. 110, 131-34 (1978) (5-1-3 split Court endorses hberal interpretation of Voting Rights Act, based in part on congressional understandings when Act was renewed in 1975); id. at 138-39 (Blackmun, J., concurring) (more strongly stated rehance on subsequent legislative understandings); Franks v. Bowman Transp. Co., 424 U.S. 747 (1976) (5-1-2 split Court allowing affirmative remedies in title VII cases and relying in part on discussions underlying 1972 amendments). On the other hand, this sort of argument failed in International Brotherhood of Teamsters v. United States, 431 U.S. 324 (1977).

217. 443 U.S. 193 (1979).

218. Justice Stewart, the necessary fifth vote in Weber (the Court split 5-2), was part of the fiveJustice majority invalidating the affirmative action plan in Regents of the University of California v. Bakke, 438 U.S. 265 (1978). Justices Stevens and Powell, who did not participate in Weber, were also part of the Bakke majority.

219. Weber, 443 U.S. at 209-16 (Blackmun, J., concurring). 
Duke Power Co. ${ }^{220}$ and to the gatekeeping committees' approval of Griggs in 1972. For these reasons, a Court critical of affirmative action in constitutional cases ended up interpreting title VII to allow a broad range of private affirmative action programs. ${ }^{221}$ The conclusion from this Weber example suggests a broader observation: The Burger Court generally produced results in constitutional civil rights cases (where there was hittle chance of its being overridden) that were discernibly more conservative than the results it reached in analogous cases of statutory interpretation. ${ }^{222}$

If the positive pohitical theory nodel's predictions were correctnamely, that the more conservative Court in the 1970s was often willing to subordimate its preferences to avoid being overruled-then Gilbert, McMann, City of Mobile v. Bolden, and Atascadero ${ }^{223}$ were anomalies, because these decisions by a bitterly divided Court were overridden by an outraged Congress. The positive political theory model would view the overrides as instances where the game did not achieve perfect equilibrium, perhaps because of a failure of one or more assuinptions. For the Court to avoid an override under the conditions of Figure 2, it inust be able to predict accurately the views of the inedian Member of Congress. There is bittle room for error (unlike under the conditions of Figure 1). In Gilbert, McMann, and Bolden, the Court inay have inisjudged the location of $\mathrm{M}$-placing it further to the right than the actual $\mathrm{M}$-and suffered the consequences, namely, legislative overrides. This is a plausible explanation, ${ }^{224}$ albeit one marred by the Court's substantial inis-

220. 401 U.S. 424 (1972).

221. Johnson v. Transportation Agency, 480 U.S. 616 (1987), confirmed this broad approval. The Johnson majority, formed when the Court was even more conservative, explicitly relied on current congressional preferences to expand on Weber. Id. at 629 n.7; see also id. at $642-47$ (Stevens, J., concurring).

222. Contrast the Burger Court's broad tolerance of voluntary affirmative action in statutory interpretation cases like Weber and Johnson with its more critical attitude in constitutional cases like Bakke, Firefighters Local Umion No. 1784 v. Stotts, 467 U.S. 561 (1984), and Wygant v. Jackson Board of Education, 476 U.S. 267 (1986). Contrast the Burger Court's willingness to look at effects upon racial groups to find actionable "discrimination" in statutory cases like Albemarle Paper Co. v. Moody, 422 U.S. 405 (1975), and Griggs, with its focus on only intentional conduct to find "discrimination" in constitutional cases like Arlington Heights v. Metropolitan Housing Corp., 429 U.S. 252 (1977), and Washington v. Davis, 426 U.S. 229 (1976).

223. See supra text accompanying notes $75-120$.

224. The Court's subsequent willingness to follow the liberal dictates of the overrides and not just their bare text supports this explanation somewhat. See Thornburg v. Gingles, 478 U.S. 30 (1986) (divided Court applies Voting Rights Amendments of 1982 very liberally); Newport News Shipbuilding \& Dry Dock Co. v. EEOC, 462 U.S. 669 (1983) (7-2 divided Court holds that Pregnancy Discrimination Act not only overruled holding of Gilbert, but also discredited its whole approach to gender discrimination). Congressional overrides of the Court's pregnancy discrimination and minority vote dilution opinions taught the Court much about the median member's preferences (M). As a consequence, the Court was able to stay out of trouble in later cases. 
perceptions in each case. ${ }^{225}$ In Part II(B), I present an alternative explanation.

\section{Court/Congress/President Confrontation: 1981-90}

In the final period, the President becoines a major player in the gaine. In the 1980s, the Court inoved somewhat further to the right of Congress (especially after 1986, when the Court moved sharply to the right and Congress to the left). The decade's biggest shift, however, was the significant inovement to the right by the Presidency. Figure 3 maps out the new preference configuration.

Figure 3

Civil Rights Preferences, 1981-90

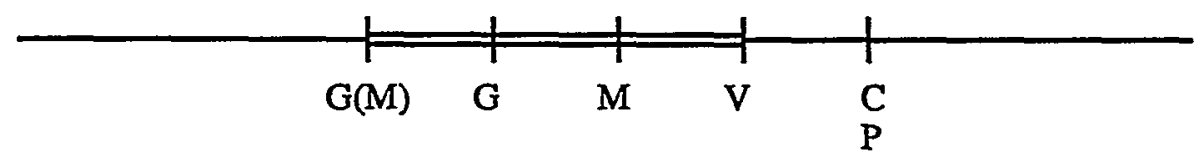

Recall that $\mathrm{V}$ is the veto median, or the point that divides the legislative chamber such that a third of the members have ideal points to the right of $\mathrm{V}$ and two-thirds have ideal points to the left. Figure 3 places the Court (C) and the Presidency (P) to the right of this veto point $(C>V ; P>V)$ for the main cases froin this period discussed in Part $I$. However, I beheve that the Court was to the left of the veto inedian (C $\langle$ V) for many civil rights issues during this period. The admimstration's position, though, remains further to the right $(\mathrm{V}<\mathrm{P})$ for soine of these issues.

Under this version of the Court/Congress/President gaine, the Court will not want to implement its own preferences when they are to the right of the veto median $(\mathrm{C}>\mathrm{V})$, because that decision would stimulate the gatekeepers to introduce overruling legislation set at V. Such legislation would not ouly be approved by Congress but also would survive an expected veto. Hence, the Court would want to shoot for a decision close to or to the left of the veto median (V). Although the gatekeepers would dislike that result, they would not introduce overruling legislation because they would realize that it would be vetoed and that they could not get Congress to override the veto. For this reason, they would live with $\mathrm{V}$.

The game depicted in Figure 3 gives the conservative Court much more discretion than it had in Figure 2, because the addition of a presidential veto protects the Court's decisions agamst overrides. Hence, we

225. In McMann, for example, the Court was aware of the Senate committee report endorsing the Fourth Circuit's decision the Court was reversing. While the Court's vote in McMann was probably taken before the committee report was promulgated, Justices have been known to change their votes during the deliberative process. 
would expect the Court's interpretation of civil rights statutes to have shifted markedly to the right in the 1980s-even more to the right than we might otherwise have expected simply from the rightward personnel changes. This scenario is basically what we find. The Court's composition changed only once between 1975 and 1986 (conservative Justice O'Connor replacing moderately conservative Justice Stewart). However, the Court's interpretations of civil rights statutes shifted dramatically to the right after 1981, when the Presidency emerged as a potential protection for the Court's conservative preferences. ${ }^{226}$ The few liberal interpretations of civil rights statutes that occurred in this period tended to einphasize recent legislative signals, ${ }^{227}$ suggesting that perhaps a few Justices were being careful to avoid results too far to the right, lest they fall athwart the veto median (V).

To see how this dynamic operates, consider the Court's position on the issue of tax exemptions for private institutions that segregate on the basis of race. Here, the positive political theory model offers a particularly good explanation for the Court's curious approach. Responding to lower court challenges, the Internal Revenue Service in 1970-71 amended its regulations to disallow incoine tax exemptions to racially discriminatory private schools. ${ }^{228}$ Although the Code and its legislative history did not strongly support the Service's position, Congress in the 1970s turned back all efforts to reverse the new rules. It did, however, hainper the agency's efforts to devote substantial resources to the regulation's

226. See, e.g., Marek v. Chesney, 473 U.S. 1 (1985) (6-3 split Court narrowly construes § 1988); Smith v. Robinson, 468 U.S. 992 (1984) (6-3 split Court narrowly construes Education of All Handicapped Children Act of 1975 and Rehabilitation Act); Grove City College v. Bell, 465 U.S. 555 (1984) (6-3 split Court narrowly construes title IX); Arizona Governing Comm. for Tax Deferred Annuity \& Deferred Compensation Plans v. Norris, 463 U.S. 1073 (1983) (4-1-4 split Court extends liberal PDA interpretation to insurance companies but does so only prospectively); City of Lockhart v. United States, 460 U.S. 125 (1983) (5-3 split Court narrowly construes Voting Rights Act); General Bldg. Contractors Ass'n v. Pennsylvania, 458 U.S. 375 (1982) (6-1-2 split Court narrowly interprets section 1981); American Tobacco Co. v. Patterson, 456 U.S. 63 (1982) (54 split Court broadly construes exception to title VII); City of Memphis v. Green, 451 U.S. 100 (1981) (6-3 sphit Court narrowly interprets section 1982). But see Connecticut v. Teal, 457 U.S. 440 (1982) (Connecticut state agency's promotion of a greater overall percentage of black employees than of white employees did not preclude black employee plaintiffs from establishing a prima facie case of disparate impact under title VII); County of Washington v. Gunther, 452 U.S. 161 (1981) (Bennett amendment to title VII does not restrict title VII prohibition of sex-based wage discrimination to equal pay for equal work claims).

227. See, e.g., Johnson v. Transportation Agency, 480 U.S. 616, 629 n.7 (1987) (5-1-3 split Court relies on subsequent congressional approval of Weber to reaffirm its view of title VII); Sehool Bd. v. Arline, 480 U.S. 273, 277-80 (1987) (7-2 split Court relies on congressional review of HEW regulations to interpret Rehabilitation Act); North Haven Bd. of Educ. v. Bell, 456 U.S. 512, 530-35 (1982) (6-3 split Court relying on legislative review and deliberation over proposed HEW regulations).

228. The IRS policy was approved iu Green v. Connally, 330 F. Supp. 1150 (S.D. Miss.), aff'd mem., 404 U.S. 997 (1971), and formalized in Rev. Rul. 71-447, 1971-2 C.B. 230. 
enforcement. ${ }^{229}$ The Supreme Court's treatment of this issue tracks the well-publicized congressional treatment. In Bob Jones University $v$. United States, ${ }^{230}$ a virtually unanimous Court upheld the agency regulation, relying heavily on Congress' supportive stance in the 1970s. ${ }^{231}$ But a year later, in Allen v. Wright, a divided Court refused to allow citizens to enforce the agency regulations directly. ${ }^{232}$

Despite this success, the positive pohtical theory inodel does not explain two important anomalies from this last period: the surprising amount and intensity of conflict between the Court/President and Congress; and the failure of each to avoid being reversed. The Court's interpretations were reversed five times after 1985 (with another nine vulnerable in the current Congress). The President's veto was overridden once. And Congress' action was thwarted once by a successful veto. The positive pohtical theory inodel might attribute these reversals to insufficient information as to the location of the veto inedian (V). That explanation, however, is problematic. Why should the Court and President make such big mistakes in this period and not in earher ones? Why should Congress have made the same mistake in 1990? This phenomenon is the biggest anomaly facing the positive political theory model as applied here, and it requires us to supplement the inodel.

\section{B. Supplementing the Positive Political Theory Model: Informational Features of the Court/Congress/President Game}

The game I have been using to model the Court/Congress/President interaction over the interpretation of civil rights statutes einphasizes the "distributive" features of the legislative process. ${ }^{233}$ The positive political theory inodel assumes that Congress delegates duties to committees and outside agents (like courts) in ways that serve its members' reelection goals. Hence, the role of committees is to distribute rents to those members (and their constituents) who inost intensely want them, and the role of agents is to carry out the members' current policies. Politics is seen as

229. For example, in 1978-79 the IRS issued regulations placing burdens on schools with low percentages of black students to "prove" nondiscrimination. Congress subsequently passed the Ashbrook Amendment, which barred the IRS from implementing those regulations. Other "back door" restrictions followed. See IRS Tax Exemptions and Segregated Private Schools: Hearing Before the Subcomm. on Civil and Constitutional Rights of the House Comm. on the Judiciary, 97th Cong., 2d Sess. 49-50 (1982).

230. 461 U.S. 574 (1983).

231. Id. at 599-602; see also id. at 607 (Powell, J., concurring).

232. 468 U.S. 737,740 (1984). The 5-3 Court held that parents of black children did not have "standing" to sue for enforcement of the IRS regulation. Id. at 740. Read in conjunction with the Bob Jones ruling, Wright indicates that the Court shares congressional sentiment: The formal IRS rule stands, but euforcement will be lax.

233. See M. Fiorina, supra note 192; D. Mayhew, supra note 192; K. Shepsle, The Giant JiGSAW PUZZLE (1978). 
a zero-sum game, in which Congress and its members scheme to divide up the pie, with minimal friction and not much attention to what is "good" policy. Equilibrium means stable outcomes in which the various players operate under perfect information to satisfy their preferences (and those of important imterest groups). Operating from these distributive assumptions, the model generates some intuitively appealing insights about civil rights overrides, but leaves several anomalies insufficiently explained, most notably the spate of legislative overrides and conflict in the past six years.

Several positive political theorists, most notably Professors Thomas Gilligan and Keith Krehbiel, have suggested that distributive features do not account for what goes on in the legislative process, and that informational features of the process deserve emphasis. ${ }^{234}$ Under this view, legislators are policy outcome-oriented, as well as reelection-oriented, but are uncertam which policies produce desired outcomes. The legislature deals with uncertainty by delegating information-gathering and consensuscreating roles to committees and other agents. Under these assumptions, equilibrium is not rent-seeking stability: instead, it means a continuous exchange of information and views within committees and between the chamber and its committees until sufficient certainty finally allows the legislature to set pohicy.

These positive political theorists do not claim that informational assumptions explain all the data on the operation of Congress. They do claim, however, that distributive assumptions do not explain it either, and my case study bears this out. These theorists make an important advance by suggesting that in our game, the players' preferences are not entirely "exogenous," that is, determined prior to playing the game. To a substantial extent, they are "endogenous," formed in the process of playing the game and im response to the information and arguments adduced by the other players. This also suggests that there is no single Court/ Congress/President game, but rather a series of games in which cominittees and agents have incentives to build up credibility by moving toward the legislative median (M). Reconsider our three periods of political interaction im light of the additional possibilities offered by considering the informational role of the players.

\section{Court/Congress/President Cooperation: $1962-72$}

Informational assumptions provide a different way of thinking about

234. See K. KreHBIEL, supra note 192; Gilligan \& Krehbiel, Organization of Informative Committees by a Rational Legislature, 34 AM. J. PoL. ScI. 531 (1990); Gilligan \& Krehbiel, Collective Choice Without Procedural Commitment, in Models of STRATEgic ChoICE IN Politics 295 (P. Ordeshook ed. 1989); T. Gilligan, Performance of an Institutionalized Legislature (1989-90) (unpublished manuscript) (on file with author). 
the initial period of cooperation among the Court, Congress, and the President on matters of civil rights policy (recall Figure 1). At the game's beginning, the views of Congress $(M)$ and the gatekeepers $(G)$ are incompletely formed, and open to change based upon more information. The Court's decision interpreting a civil rights statute (C) consequently becomes relevant information that might be considered, first, by the gatekeepers and, then, by the entire Congress. Three outcomes are possible, given the initial (and now only tentative) preference mapping for this period in Figure 1.

The first possible outcome I call the "information variation." Under this outcome, the relevant committees will examine the facts and reasoning of the Court's decision and agree with it. If the committee agrees with the decision, obviously it does not lave to do anything. Moreover, sometimes the committee will even use the decision as a building block for new statutory initiatives. For example, the judiciary cominittees followed this course in using Allen v. State Board of Elections as a foundation for their thinking durmg the 1970 reenactment of the Voting Rights Act; the labor committees did the same when they considered Griggs similarly in the context of title VII's 1972 amendment. When the Court's opinion itself calls for legislative action to build upon its opinion, as in Guest, the committees will be particularly hikely to press for codifying legislation.

The second possible outcome is the "distributive variation" discussed above: The gatekeeping committees will not agree with the Court's decision, but will not take action to overrule it because they do not prefer the decision Congress would probably adopt. Notwithstanding informational features of the political process, distributive features remain strong possibilities for the Court/Congress/President gaine. ${ }^{235}$ Indeed, the distributive variation reinains a robust positive political explanation of Congress' failure to overrule Jones $v$. Mayer.

The third possible outcoine is a hybrid of the first two: The gatekeeping committees will be persuaded by the Court's decision and will shift their preferences (G) in the direction of the Court's (C); however, they will not imitiate statutory proposals to codify or build upon the

235. Information theorists might argue, first, that this will occur in a narrow range of cases, because the preferences of committees (G) will not be far from those of the mediau Member (M). These theorists argue that committees are generally not composed of preference "outliers," and I think they are largely correct. However, even their own evidence suggests that the Labor and Judiciary committees in the 1980 s were more liberal than the median Member.

Information theorists would argue, second, that the relevant committees are not gatekeepers, because they cannot prevent Congress from considering issues. There is much to this argument. In all the case examples I have discussed for this period, Congress had its chance to vote. But I consider the gatekeepers to be the committees plus the Democratic leadership, which together do substantially control the agenda of Congress and did play a critical role, for example, in turning back the floor challenges to the Jones $v$. Mayer interpretation in 1971-72. 
Court's decision because they are unsure that Congress will agree (they are not sure $M$ will shift toward $C$ ). This is a plausible explanation of the congressional response to Griggs: The very liberal labor committees in both chambers were persuaded by the Griggs opinion (and wrote committee reports to that effect) but never sought to codify it in title VII, since they were not certain that Congress would be similarly persuaded.

\section{Court/Congress Conflict: $1972-81$}

Informational assumptions also provide a different way of looking at our second period, in which the Court's rightward shift yielded a number of overrides. The Court as an institution was trying to do more than just accommodate its preferences to those of Congress. Sometimes the Court was trying to change congressional preferences through persuasive opinions. Under this more coinplex set of assumptions, there are again three types of outcomes that might flow froin the tentative preference mappings in Figure 2.

Under one possible outcome-the information variation-the Court will stick to its preferences and try to persuade the gatekeepers and Congress of its views. This is a very hard task, since it is especially important to persuade the gatekeepers, whose preferences $(G)$ are more distant from the Court's (C) than Congress' (M) are. This scenario appears to be the one that the Court tried to follow in Gilbert, Bolden, and Atascadero. All three opinions were based upon the Court's conservative constitutional jurisprudence-fourteenth amendment gender discrimination, fifteenth anendment voting rights, and eleventh amendment state sovereign iminunity, respectively - and inight be interpreted as extensions of that jurisprudence. In these opinions, therefore, the Court was informing Congress of an important body of constitutional law and suggesting that the statutory law should run along parallel lines. Even though Congress declined to follow the Court's lead in each case, it did so only after considering the gatekeepers' thorough factfinding and reports, which discredited the Court's analysis.

Under the second possibility-the distributive variation-the Court will adjust its preferences in deference to those of the legislature and will successfully avoid an override. I think this is precisely what the Court did explicitly in Runyon and implicitly in Weber and a number of other civil rights decisions of the $1970 \mathrm{~s}^{236}$ The distributive variation would explain cases like Gilbert by suggesting that the Court was simply mistaken about the congressional inedian. This conclusion strikes me as also plausible.

A third possible outcome, something of a hybrid, is that the Court 
will signal Congress that its policy preferences might be different from its institutional preferences, thereby inviting a legislative override. This, I beheve, is what the Court was doing im Alyeska Pipeline. The Court understood that, as a matter of policy, fee shifting made sense in public law litigation. The Court, however, did not feel comfortable adopting this fee shifting, in liglit of two factors: the relative clarity of tlie statutes limiting a court's authority to award counsel fees to the prevailing party and Congress' repeated willingness - in the 1960 s and early 1970 s-to adopt specific fee-shifting statutes tailored to specific statutory schemes wlien it wanted thein. The Court's opimion provided Congress witl useful information, and openly invited an override, to do wliat the Court felt incapable of doing.

\section{Court/Congress/President Conflict: 1981-90}

Informational assumptions also provide a useful perspective for thinking about our third period, in wlich a strong riglitward sliff in tlie Presidency not only supported tlie expected rightward shift in tlie Supreme Court opimions, but also ultimately contributed to four years of unprecedented conflict between the Court/President, on one side, and Congress, on the other. Again, these assumptions expand tlie possible outcomes of this revised gaine, in whicli tlie President became a major player in trying to protect the Court from Congress-especially after 1986, when Congress moved to tlie left and the Court sliarply to the right (recall Figure 3).

One possible outcome is an information variation. The Court will implement its preferences as the decision $(\mathrm{x}=\mathrm{C})$ but will write an opinion providing Congress with useful information, in hopes of persuading enough Members of Congress to shift the veto median (V) to the right. The Court may liave taken tlis attitude in Grove City and Betts, both of whicl proved dramatically unpersuasive to large majorities in Congress. Interestingly, the Court was probably trying to do this in Wards Cove, Martin v. Wilks, and Zipes, three of the six 1989 decisions subject to the 1990 civil rights bill.

In eacli of these opinions, the Court articulated important policy concerns that miglit liave moved tlie veto median. Wards Cove and Martin reflected the Court's concern that tlie dynamics of title VII actions gave employers perverse incentives to adopt racial quotas. As a result, the Court in Wards Cove inade plaintiffs' burden of proof in disparate impact cases more demanding to ensure that employers were not pressured to shoot for completely "proportional representation" by minorities, as through quotas. ${ }^{237}$ The Court in Martin v. Wilks relied on

237. See Wards Cove, 490 U.S. at 652 (criticizing lower court's Griggs-based approach on the 
standard due process values to assure procedural avenues for future white employees to reopen consent decrees to make "reverse discrimination" claims. ${ }^{238}$ This is also a plausible explanation for Zipes, where the Court was concerned about the rights of intervening defendants. ${ }^{239}$ That the President's veto of the 1990 civil rights bill was not overridden might suggest that the Court was successful in moving the veto median on these issues, though I think the third variation, described below, offers an even better explanation.

Another possible outcome is suggested by the distributive variation set forth imitially: Even though the Court's decision is to the right of the preferences of Congress, it will try to avoid an override, by moving its own preferences toward what the Court perceives to be the veto median. This move does indeed explain most of the cases and suggests that soine of the congressional overrides may have been a result of the Court's miscalculation of the veto median. For example, Patterson was clearly a compromise decision, in which the five-Justice majority reaffirmed Runyon v. McCrary as "consistent with our society's deep commitment to the eradication of discrimination based on a person's race," 240 but then interpreted Runyon rather narrowly, based in part on its clash with the original assumptions of title VII. ${ }^{241}$ Such a decision at least seemed to signal an accommodating attitude toward current legislative preferences. $^{242}$ Much the same story can be told for Smith $v$. Robinson, Paralyzed Veterans of America, and Price Waterhouse v. Hopkins. ${ }^{243}$ On the other hand, this game does not adequately explain Grove City, Betts, and probably some of the 1989 decisions currently being considered for override by Congress (such as Lorance), where the Court's miscalculations were quite substantial.

A third possible outcome, a hybrid of the informational and distrib-

grounds that it would impel "many employers . . . to adopt racial quotas," in violation of section 703(j)).

238. See Martin v. Wilks, 490 U.S. at $761,762 \mathrm{n} .2$ (ironically relying on Hansberry v. Lee, 311 U.S. 32, 40 (1940), which allowed a collateral challenge to a decree segregating a Chicago neighborhood).

239. See Independent Fed'n of Flight Attendants v. Zipes, 491 U.S. 754, 761-66 (1989).

240. Patterson v. McClean Credit Union, 491 U.S. 164, 174 (1989).

241. Id. at 177-82.

242. Members of Congress took the unusual step of filing an amicus brief in Patterson. The brief argued only for reaffirming Runyon v. McCrary, 427 U.S. 160 (1976); it did not tackle the difficult issue of applying Runyon to Patterson's facts. See Brief of 66 Members of the United States Senate and 118 Members of the United States House of Representatives as Amici Curiae in Support of Petitioner, Patterson (No. 87-107). In light of this brief, the Patterson opinion may be seen as responding to congressional concerns, or at least to the Court's understanding of those concerns.

243. After being overridden three times in 1986 in its interpretations of statutes affecting the handicapped, see Department of Transp. v. Paralyzed Veterans of Am., 477 U.S. 597 (1986); Atascadero State Hosp. v. Scanlon, 473 U.S. 234 (1985); Smith v. Robinson, 468 U.S. 992 (1984), the Court changed course the next year by broadly construing section 504 of the Rehabilitation Act in School Board v. Arline, 480 U.S. 273 (1987). 
utive variations, is that the Court will write an opinion trying to shift the veto median to the right, and the gatekeepers will respond by mounting an effort to shift the veto median to the left. The gatekeepers appear to have done just this in 1988 with the Restoration Act. The Act not only overruled Grove City's interpretation of title IX, but went beyond the position of the Grove City dissenters and expanded federal antidiscrimination rules to entire "systems."244 Seeking to repeat their 1988 success, the gatekeepers tried to do the same thing in 1990. The Court's decisions in the six 1989 cases-Wards Cove, Martin v. Wilks, Patterson, Hopkins, Lorance, Zipes-were extremely vulnerable in Congress because its policy preferences were too far to the right and so bereft of persuasive power that even the President deserted the Court on Patterson and Lorance.

As a result, the gatekeepers could have drafted a bill overruling most of these decisions (probably all but Ward's Cove) at the veto median (V) and could have been successful. But from the gatekeepers' point of view, such a decision $(x=V)$ would have been little better than the Court's decisions $(x=C>V)$. Hencc, the gatekeepers themselves sought to move the veto median (V) and the median member $(M)$ to the left on soine of the relevant issues (especially the Wards Cove issue) through extensive hearings detailing the unfortunate practical effects of the decisions on civil rights enforcement. The 1990 experience suggests that the gatekeepers did not move the veto median far enough to the left (the veto was not overridden). But it also suggests that a less ambitious bill introduced to the current Congress could pass, because most of the Court's decisions appear to be to the right of the veto median.

\section{Positive Predictions for Court/Congress/President Interaction on Civil Rights Issues in the 1990s}

Positive political analysis not only provides explanations about the past but can suggest the direction of future Court/Congress/President interaction regarding civil rights statutes. One prediction is that Congress im 1991 or 1992 ought to be able to enact legislation overruling most or all of the nine Supreme Court decisions subject to the vetoed 1990 bill. The inam obstacle to an override is not the prospect of another presidential veto, but the possible failure of the gatekeepers to develop a bill tailored to the veto median (yielding a bill the President would ordi-

244. See Civil Rights Restoration Act of 1985: Joint Hearings on H.R. 700 Before the House Comm. on Education and Labor and the Subcomm. on Civil and Constitutional Rights of the House Comm. on the Judiciary, 99th Cong., 1st Sess. 12, 174, 404-05, 599 (1985) (statements of Rep. Sensenbrenner (R-Wis.)). Rep. Sensenbrenner believed Grove City was wrongly decided and supported both bills but felt that the 1985 bill did more than overrule Grove City. See also id. at 23136 (similar testimony by Assistant Attorney General Reynolds). 
narily not veto, whatever his own preferences). For example, a bill overruling Patterson and Lorance (which the administration supported in 1990) could pass without a veto. A bill also overruling Hopkins, Zipes, and the three minor pre-1989 cases $^{245}$ could probably pass with vetoproof margins. With larger Democratic majorities in Congress, the gatekeepers also ought to be able to pass a bill modifying Wards Cove and Martin v. Wilks.

The more interesting question is what the dynamics for Court/ Congress/President interaction will be for future Supreme Court decisions interpreting civil rights statutes. The dynamics are, I think, fairly established for the 1990s: The Court's preferences will remain to the right of Congress' preferences which in turn will be to the right of the preferences of the majority leadership and one of the two gatekeeping committees (the labor committees). ${ }^{246}$ The three variables that will be important for the dynainics under the Court/Congress/President civil rights game developed in this Part are the preferences of the Presidency, the strategy of the Court, and the strategy of the gatekeepers. Consider some of the variations.

One possible (and in my view hikely) scenario is a reduction of open Court/Congress conflict (after the 1991/92 bill is passed), even though the Court's own preferences will probably drift to the right, at least in the early 1990s. ${ }^{247}$ The key variable will be whether the Court decides to compromise its preferences as it did m most of the civil rights cases of the

245. See cases cited supra note 15.

246. I assume here that the Democrats will retain their majorities in Congress, which seems very probable for the House and probable for the Senate. If so, Congress will remain substantially to the left of the Court, whose left-leaning Justices are relatively older than the right-leaning Justices (and hence more likely to be replaced). Even if the Republicans take control of the Senate, Congress as a whole will remain to the left of the Court on most civil rights issues.

If the Democrats retain their control of Congress, the majority leadership will likely remain to the left of the chamber median, as is currently the case with Majority Leader Mitchell (D-Me., 1988 ADA score 95) and Speaker Foley (D-Wash., 1988 ADA score 85). If the Republicans take control of Congress, the majority leadership will shift to the right of the chamber median, as is currently the case with House Minority Leader Michel (R-Ill., 1988 ADA score 10) and Senate Minority Leader Dole (R-Kan., 1988 ADA score 15). See The AlmanaC of AMERICAN Politics 1990, supra note 52 (listing the inembers' ADA scores).

Whichever party controls Congress, the labor cominittees will probably remain significantly to the left of the chamber median; the judiciary committees will probably stay pretty inuch at the chamber inedian (as has historically been the case). See K. KREHBIEL, supra note 192, ch. 4 (discussing House coinmittees). For example, the 1990 Senate Judiciary Committee's Deinocratic nembers had an average 1988 ADA score of 74; its Republican members, 15. The two scores of 74 and 15 mirrored the chamber medians of 72 and 19, respectively. However, the average scores on the 1990 Senate Labor and Human Resources Committee differed significantly from these chamber medians. Deinocratic members had average 1988 ADA scores of 88, and its Republican members, 26. These numbers are inarkedly higher than the chamber medians, as listed above. See THE Almanac of AMERICAN Polmics 1990, supra note 52, for these ADA scores.

247. Liberal Justice Brennan's replacement by Justice Souter, who is probably more conservative, accounts for this rightward shift. Other moderate-to-liberal Justices (Marshall, 
1970s. In the short term (with a conservative President), the Court only has to aim at the veto median (V). This strategy will still permit the Court plenty of discretion to reach conservative results. In the longer term, depending on the future preferences of the Presidency, the Court may have to aim at the congressional median (M) in order to accommodate the political system and avoid overrides.

The Court has strong incentives to follow this course under the Court/Congress/President civil rights game outhned here. Under the distributive variation, the Court's incentive to accommodate its preferences is simply to avoid being overridden. Under the information variation, the Court might want to risk being overridden in order to persuade Congress that the Court's policy is better. In that event, the Court still has an incentive not to be overridden constantly. That is, if the Court wants to be seen as generating useful information for Congress, it will lose its credibility if Congress continually rejects its information as unreliable by overruling its decisions. In the past, this incentive has motivated the Court to become more moderate when its policy initiatives were rebuffed by Congress. ${ }^{248}$ On the other hand, if the Court decides to "dig in" and continue to try to persuade Congress to accept its policies, the Court/Congress conflict will continue into the 1990s.

Whether or not the Court/Congress conflict continues, the actual direction of civil rights statutory policy will depend largely on the preferences of the Presidency in the 1990s. If the Presidency remains where it is (on the right), policy will end up somewhere around the congressional veto median $(x=V)$. This would mean greater restrictions on statutorily permitted affirmative action, narrower interpretations of section 1981 and other general civil rights laws, and greater procedural burdens on civil rights plaintiffs. If the Presidency shifts to the left, either to or beyond the congressional median $(P<M)$, then the Court loses a great deal of its discretion, and the ultimate policy decision shifts toward the congressional median (M).

Given the Court's current preferences $(C>M$ for the entire decade), the election of a President whose civil rights preferences are at or to the left of Congress' preferences would clearly affect civil rights policy in the game. At the very least, a more liberal President would reınove the veto protection for the Court, and policy would inove back toward the congressional median. More dramatically, the President's ability to persuade and lead opinion could move the congressional median $(M)$ to the left (as the President did in the 1960s). Such a movement would have a substantial influence on policy, notwithstanding the Court's position.

Blackmun, Stevens) may well leave the Court in time for the Bush administration to appoint more conservative Justices.

248. For example, see the Court's positive response to the PDA, discussed supra note 224. 
The consequences would include statutory allowance of voluntary affirmative action, broader interpretations of the civil rights statutes to reach new and unanticipated problems, and fewer procedural obstacles to civil rights enforcement.

\section{III \\ NoRMative IMPLICATIONS OF THE GAME THEORY ANALYSIS OF THE COURT/CONGRESS/PrESIDENT INTERACTION}

The normative imphications of the positive political theory model are also of interest. The model strongly suggests that the Court is a political actor: The Court imposes its own preferences onto civil rights statutes, subject mainly to the constraints imposed by the preferences of the current President and Congress. This positive political suggestion contrasts dramatically with the traditional law professor's view of the Court as merely an agent implementing the intent of the original legislature. ${ }^{249}$ Yet the traditional view fails to account for the last thirty years of the Court's interpretations of civil rights statutes. Virtually all the inportant judicial interpretations of civil rights statutes during this period either do not explore the original legislative intent or expectations in any meaningful way, ${ }^{250}$ or else they rely on arguments about those expectations that

249. See, e.g., The FEDERALIST No. 78 (A. Hamilton) ("[T]he judiciary, from the nature of its functions, will always be the least dangerous to the political rights of the Constitution ...."); Maltz, Statutory Interpretation and Legislative Power: The Case for a Modified Intentionalist Approach, 63 TUL. L. REv. 1, 13 (1988) (an intentionalist approach to statutory interpretation "embodies widely shared, deeply embedded beliefs about the appropriate scope of legislative power"); Landes \& Posner, The Independent Judiciary in an Interest-Group Perspective, 18 J.L. \& EcoN. 875, 877-87 (1975) (interest-group theory posits that an independent judiciary will enforce existing statutes in accordance with the enacting legislature's intent); Merrill, The Common Law Powers of Federal Courts, 52 U. CHr. L. Rev. 1, 19-24 (1985) (the principle of separation of powers limits the legitimacy of lawmaking by federal courts). But see M. SHAPIRo, LAw AND Politics in the SUPREME COURT (1964) (the Supreme Court is often the agent of interest groups not represented adequately by other institutions of government).

250. See Public Employees Retirement Sys. v. Betts, 109 S. Ct. 2854, 2860-64 (1989) (skirting the legislative history arguments and concluding they have no relevance given the "plain statutory language," id. at 2864); Independent Fed'n of Flight Attendants v. Zipes, 491 U.S. 754, 758-66 (1989) (interpreting title VII "in light of the competing equities that Congress normally takes into aceount," id. at 761, but iguoring legislative intent); Patterson v. McLean Credit Union, 491 U.S. $164,175-85$ (1989) (analysis focuses on plain meaning and precedent with only scant attention to legislative history); Lorance v. AT\&T Technologies, 490 U.S. 900 (1989) (similar); Martin v. Wilks, 490 U.S. 755 (1989) (ignoring title VII altogether); Wards Cove Packing Co. v. Atonio, 490 U.S. 642 (1989) (iguoring legislative intent); Atascadero State Hosp. v. Scanlon, 473 U.S. 234, 237-47 (1985) (emphasizing federalism policy and iguoring legislative expectations); City of Mobile v. Bolden, 446 U.S. 55, 60-61 (1980) (using admittedly scant legislative history to suggest that plaintiffs' statutory claim only duplicated their fifteenth amendment claim); General Elec. Co. v. Gilbert, 429 U.S. 125, 133-40 (1976) (interpreting title VII in light of equal protection jurisprudence and ignoring legislative intent); Louisiana v. United States, 380 U.S. 145, 147-56 (1965) (no discussion of legislative intent). 
range from questionable ${ }^{251}$ to untenable. ${ }^{252}$ Furthermore, many of the decisions explicitly rely upon pohtical developments after the statute's enactment. $^{253}$

I am hardly the first to suggest that the Court is a pohtical actor, for the legal realists long ago demonstrated that the Court's decisions do not necessarily flow from primcipled rules and that the Court decides cases based in part upon its own preferences. A fair amount of recent legal scholarship has demonstrated that many of the Court's decisions represent no consistent effort to rephicate the original intent of the enacting Congress. ${ }^{254}$ And there is a rich tradition of positive political theory that successfully explains outcomes from models that treat the Court as a political actor not much different from agencies, the President, and Congress. ${ }^{255}$

My historical account through the lens of a positive political theory model is further evidence that the Court does not faithfully follow the

251. Compare Library of Congress v. Shaw, 478 U.S. 310, 319-20 (1986) (majority opinion) (title VII provision making the United States liable "the same as a private person" waives the government's immunity from attorney's fees, but not imterest, because neither the statute, nor the legislative history specifically mention "interest") with id. at 325-26 (Brennan, J., dissenting) (preclusion of interest inconsistent with actual congressional expectations). Compare Smith v. Robinson, 468 U.S. 992, 1006-13 (1984) (majority opinion's use of legislative intent) with id. at 102631 (Brennan, J., dissenting) (persuasive rebuttal based on underlying congressional assumptions). Compare United Airlmes v. McMann, 434 U.S. 192, 199-202 (1977) (majority opinion's interpretation of legislative history) with id. at 210-16 (Marshall, J. dissenting) (detailed rebuttal). Compare Jones v. Alfred H. Mayer Co., 392 U.S. 409, 422-37 (1968) (majority opinion's detailed examination of legislative history) with id. at 450-76 (Harlan, J., dissenting) (even more detailed rebuttal).

252. A striking example is Grove City College v. Bell, 465 U.S. 555 (1984). In Grove City, a unanimous Court relied on legislative history to conclude that student receipt of federal financial aid triggers title IX's application to the college. Id. at 565-70. A majority then summarily rejected compelling legislative history which indicated that title IX was intended to cover a whole college. Compare id. at 570-71 (majority opinion) with id. at 582-99 (Brennan, J., concurring in part and dissenting in part). See also B. Marks, supra note 195 (original legislative history); id. at 71-78 (subsequent legislative history). Compare also Griggs v. Duke Power Co., 401 U.S. 424, 434-36 (1971) (unanimous Court's use of legislative inteut in title VII) with H. GRAHAM, supra note 22 (Court's use of legislative intent in Griggs is spurious).

253. See Patterson, 491 U.S. at $180-82$ (interpreting section 1981 narrowly so as not "to circumvent the detailed reniedial scheme constructed" in [the later] title VII); Atascadero, 473 U.S. at 237-47 (relying on post-EHA eleventh amendment jurisprndence to interpret statute); Bolden, 446 U.S. at 60-74 (relying on post-Voting Rights Act fifteenth amendment jurisprudence to interpret statute); Gilbert, 429 U.S. at 133-40 (relying on post-title VII fourteenth amendment sex discrimination jurisprudence to interpret title VII).

254. Eskridge \& Frickey, Statutory Interpretation as Practical Reasoning, 42 STAN. L. REv. 321, 325-32 (1990); Farber, supra note 20; Frickey, Congressional Intent, Practical Reasoning, and the Dynamic Nature of Federal Indian Law, 78 CALIf. L. REv. 1137, 1142-203 (1990) (careful demonstration of how the Court has ignored or abused legislative history in interpreting federal Indian law); Zeppos, Judicial Candor and Statutory Interpretation, 78 Geo. L.J. 353 (1989).

255. See C. Pritchett, The Roosevelt Court (1948); D. Rhode \& H. Spaeth, Supreme Court Decision Making (1976); G. Schubert, The Judicial Mind: The ATtitudes and IDEOLOGIES OF SUPREME COURT JUSTICES, 1946-1963 (1965); Segal \& Cover, supra note 61. 
traditional approach to statutory interpretation. This positive account also inakes an interesting affirmative point: The Court is often attentive to the current Congress' preferences when it interprets statutes; therefore, these interpretations can then be interpreted as political efforts by the Court to accommodate its views to those of Congress, or to persuade Congress to change its views.

If the Court is-consciously or unconsciously-engaging in this sort of game with Congress, there are interesting normative ramifications. I explore three of them here: first, a reevaluation of traditional doctrines relating to the Court's interpretation of statutes; second, a rethinking of the meaning of judicial activism; and third, a reevaluation of the Court's role in civil rights policy.

\section{A. Rethinking Specific Doctrines}

Most traditional doctrimes of statutory interpretation are, at least rhetorically, grounded upon original intent theory. Consequently, the Court's political role in the evolution of the nation's civil rights policy suggests that some of these doctrimes should be reconsidered, at least in the context of implementimg civil rights statutes. I shall examine three such doctrines here-the retroactivity of judicial decisions, the rule agamst using subsequent legislative history, and various legislative inaction rules.

\section{Retroactivity of Supreme Court Interpretations of Civil Rights Statutes}

The traditional, but not iron-clad, rule has been that legislation only applies prospectively, whereas judicial interpretation of legislation applies retroactively. ${ }^{256}$ Sometimes when the Supreme Court overrules prior decisions (especially constitutional decisions), it will give the new rule only prospective effect. ${ }^{257}$ Sometimes Congress will give retroactive effect to statutory changes it makes in the law. ${ }^{258}$ But when the Court is merely interpreting statutes and not explicitly overruling prior interpretations, it almost always gives its decisions retroactive effect. So, too, Congress has traditionally overridden the Court's interpretations by legislating only prospectively.

This dichotomy is based on the traditional view of the different roles of Court and Congress. Since the Court "declares" the preexisting law, its decisions apply not only to the case or controversy at hand, but also to all others pending. Since Congress "creates" new law through the polit-

256. See W. Eskridge \& P. Frickey, Legislation: Statutes and the Creation of Public Policy $264-77$ (1987) (exploring the traditional view and some critiques of it).

257. See id. at $264-70$.

258. Id. at 274-77. 
ical process, it would be unfair to apply its "new" rules to preexisting transactions. The legal realists' demonstration that courts create law in some of the same ways that legislatures do has discredited this traditional rationale. $^{259}$ Yet a study of our present practices reveals how strongly the old dichotomy hives on. For example, even the very liberal House Education and Labor Committee came close to removing the retroactivity provisions of the omnibus 1990 bill, based upon these traditional arguments. ${ }^{260}$

This historical study also suggests a strong reason for why the Court and Congress should abandon the dichotomy in inany cases. On the one hand, Congress should feel hittle reluctance to override judicial misinterpretations retroactively. Congress did this in the $1986 \mathrm{HCPA}$ and tried to do so in the 1990 Civil Rights Act. The imperative towards retroactivity is greater when good evidence exists that the Court's interpretation alters "settled" expectations, as it did in Jones v. Mayer, Gilbert, McMann, Bolden, Grove City, Robinson, Atascadero, Betts, Martin v. Wilks, Wards Cove, and several of the other 1989 decisions. Indeed, when the Court's interpretation changes a settled agency and lower court consensus and Congress overrides the Court's novel interpretation, Congress ought to presume in favor of soine form of retroactivity. On the other hand, the Court should reconsider its policy of retroactive application for decisions that in reality represent shifts of law. In such cases, it makes sense for the Court to give its decisions "prospective-prospective" effect; that is, the Court's interpretation should apply a year or two years from the date of the decision, so that Congress can respond to the Court's new information. ${ }^{261}$

\section{Subsequent Legislative History}

The traditional (original imtent) theory suggests that the Court should not consider subsequent legislative history when interpreting stat-

259. See, e.g., Traynor, Quo Vadis, Prospective Overruling: A Question of Judicial Responsibility, 28 HASTINGS L.J. 533, 534-42 (1977).

260. Representative Moorehead's (R-Cal.) motion to strike the retroactivity provisions passed by an 18-17 vote. Suddenly, another Democrat on the committee popped up (probably dragged from some other meeting) to vote with the chair and kill the motion on an 18-18 tie. It is interesting that this was the only significant Repubhican motion to come anywhere close to adoption by the liberal committee. See Marked Transcript of the House Education and Labor Committee (available from the Committee only).

261. This is hardly a novel strategy. State courts sometimes do this in seeking to call legislative attention to a problem. See, e.g., Spanel v. Monnds View School Dist. No. 621, 264 Minn. 279, 118 N.W.2d 795 (1962) (prospectively overruling the doctrine of sovereign immunity for Minnesota school districts with respect to torts committed after the adjournment of the following regular session of the Minnesota Legislature). The Supreme Court used the same strategy in Northern Pipeline Co. v. Marathon Pipe Line Co., 458 U.S. 50 (1982) (prospective overruling only of an unconstitutional provision of the Bankruptcy Act of 1978). See G. CALABRES1, A COMmON LAW FOR THE AGE OF STATUTES (1982), for an excellent analysis of this concept. 
utes. Indeed, the Burger Court in 1980 invoked "the oft-repeated warning that 'the views of a subsequent Congress form a hazardous basis for inferring the intent of an earlier one." "\$262 The Court, also in 1980, said that although arguments based on subsequent legislative history "must be weighed with extreme care, they should not be rejected out of hand as a source that a court inay consider in the search for legislative intent."263 And in yet a third 1980 case, the Court said that, "while the views of a subsequent Congress cannot override the unmistakable intent of the enacting one, ... such views are entitled to significant weight . . . and particularly so when the precise intent of the enacting Congress is obscure." 264

Obviously, the Burger Court had no hard-and-fast rule concerning subsequent legislative history. The positive political theory model developed in this Article would predict that the Court would be inore likely to emphasize subsequent legislative history when it is trying to accommodate its preferences to those of Congress. Moreover, there is some evidence that the Court does exactly that. In North Haven Board of Education v. Bell, ${ }^{265}$ for example, the Court hiberally interpreted title IX to include employinent discrimination. We could plausibly conclude that this interpretation reflected the Court's deference to a strong majority view in Congress to that effect. In fact, the Court's opinion emphasized subsequent legislative history. ${ }^{266}$ Quoting another title IX case in which the Court bent its preferences toward those of the congressional inedian, the Court in North Haven said: "Although postenactment developinents cannot be accorded 'the weight of contemporary legislative history, we would be remiss if we ignored these authoritative expressions concerning the scope and purpose of Title IX ...." reluctantly interpreted title IX to grant a private right of action. Two years later, the Court in Grove City rehed on subsequent legislative history to reject the college's argunent that federal financial aid to its students did not bring the college into title IX's ambit, ${ }^{268}$ but then essentially ignored similarly informative subsequent legislative history cutting against its holding that ouly the college's financial aid operations (and not the entire college) fell within title IX.269

262. Consumer Prods. Safety Comm'n v. GTE Sylvania, 447 U.S. 102, 117-18 (1980) (quoting United States v. Price, 361 U.S. 304, 313 (1960)).

263. Andrus v. Shell Oil Co., 446 U.S. 657, 666 n.8 (1980).

264. Seatrain Shipbuilding Corp. v. Shell Oil Co., 444 U.S. 572, 596 (1980) (citations omitted).

265. 456 U.S. 512 (1982).

266. Id. at 531-35 (HEW regulations considered by Congress and not overruled; indeed, proposals to change the regulations were defeated).

267. Id. at 535 (quoting Cannon v. University of Chieago, 441 U.S. 677, 687 n.7 (1979)).

268. Grove City College v. Bell, 465 U.S. 555, 568-70 \& 568 n.19 (1984).

269. Id. at 572-75; cf. id. at $592-99$ (Brennan, J., concurring in part and dissenting in part) (detailed examination of subsequent legislative history bearing on this issue). 
The Rehnquist Court's move to the right and its unwillingness to bend its interpretations to current congressional preferences are inirrored in its much more consistent rhetoric against the use of subsequent legislative history. In Betts, for example, the Court marginalized Congress' 1978 overruling of McMann and stated: "We have observed on more than one occasion that the interpretation given by one Congress (or a committee or member thereof) to an earlier statute is of hittle assistance in discerning the meaning of that statute."270 The Rehnquist Court consistently inveighs against the use of subsequent legislative history, ${ }^{271}$ though it has not hesitated to use subsequent statutes to inform its interpretations. ${ }^{272}$ Indeed, the Rehnquist Court's refusal to acknowledge recent legislative expressions of preference is probably loosely correlated to the Court's provocatively conservative interpretations of civil rights laws.

Generally, the analysis in this Article suggests a normative justification for the Burger Court's practice of softening its conservative preferences as it looked to subsequent legislative history. The use of subsequent history may seem inconsistent with original intent theories of statutory interpretation; however, the practice of the Warren, Burger, and Rehnquist Courts has borne little resemblance to an original intent approach in civil rights cases. To the extent that the Court is a pohtical actor in civil rights cases and is making public policy, it ought to consider current legislative views both to inform its own policy clioices and to avoid an unnecessary legislative overruling. The analysis also suggests a normative problem with the Rehnquist Court's refusal to credit subsequent legislative history: that refusal has deprived the Court of useful political information and has contributed to confrontations witl Congress.

Some current Justices may believe that it is liealtliy for the Court to prod Congress, rather than for the Court to update civil rights statutes (which they believe their conservative decisions do not). If that is the

270. Public Employees Retirement Sys. v. Betts, 109 S. Ct. 2854, 2861 (1989).

271. See, e.g., United States v. Monsanto, 491 U.S. 600, 609-10 (1989) (disregarding postenactnient statenients of several legislators); Mackey v. Lanier Collections Agency \& Serv., 486 U.S. 825, $839-40$ (1988) (subsequent legislative history, absent an amendment to the original language of the statute, should not direct resolution of a case); Gwaltney of Smithfield v. Chesapeake Bay Found., 484 U.S. 49, 63 n.4 (1987) ("The conclusions of the 99th Congress, however, are hardly probative of the intent of the $92 \mathrm{~d}$ Congress.").

272. E.g., Jett v. Dallas Indep. School Dist., 491 U.S. 701, $711-31$ (1989) (interpreting the Civil Rights Act of 1866 in light of the Civil Rights Act of 1871); Patterson v. McLean Credit Union, 491 U.S. 164, 181 (1989) ("We should be reluctant ... to read an earlier statute broadly where the result is to circunivent the detailed remedial scheme constructed iu a later statute."); United States v. Fausto, 484 U.S. 439, 453 (1988) ("[R]econciling nuany laws enacted over time, and getting them to 'make sense' in combination, necessarily assumes that the implieations of a statute may be altered by the iniplieations of a later statute."). 
Justices' behef, the analysis in this Article carries with it a normative doctrimal suggestion: The Justices should at least consult subsequent legislative history and other recent materials before deciding whether to give their conservative decisions prospective-prospective effect. In sum, if the Court wants Congress to take responsibility for updating civil rights statutes, it should provide a clear signal to that effect by making its own decisions prospective (especially when they change previously settled understandings).

\section{Legislative Inaction}

The Court im general, and even the Rehnquist Court, has relied on one type of subsequent legislative history: "legislative inaction," namely, the failure of Congress to overrule Supreme Court decisions, lower court consensus, and/or agency regulations. ${ }^{273}$ The analysis in this Article suggests that the Court's reliance on legislative inaction is most productive when it sheds light on current legislative preferences (as to either the congressional median or the veto median). To the extent this suggestion is correct, the Court ouglit to be more critical than it has been in the past.

The most questionable of the legislative inaction doctrines is the acquiescence rule, in which the Court follows a precedent or agency rule on the basis that Congress never overruled it. For example, in Johnson v. Transportation Agency, 274 the Court reaffirmed Weber based upon Congress' failure to overrule it and the mistaken belief that there had been no attempt to do so. ${ }^{275}$ In reality, the failure of Congress to act against Supreme Court precedents says very little about the preferences of the congressional median. For the gatekeepers may favor the decision and, as a consequence, may not imtroduce or may at least block overruling legislation. The gatekeepers, however, may have preferences different from those of the chainber median; therefore, the failure to act may be attributed to gatekeeper preference rather than the preference of Congress as a whole. This may have been the case with Weber. ${ }^{276}$

273. See Eskridge, supra note 213 (analyzing the Court's recent treatment of legislative inaction); Grabow, Congressional Silence and the Search for Legislative Intent: A Venture Into "Speculative Unrealities," 64 B.U.L. REv. 737 (1985) (critically noting the Court's increased reliance on congressional silence or inaction as an aid to statutory construction).

274. 480 U.S. 616 (1987).

275. Id. at 629 n.7. The Court was wrong in thinking that no bill had even been introduced to overrule Weber, since that was the purpose of S.J. Res. 41, 97th Cong., 1st Sess. (1981), and was the basis for Senate hearings. See Affirmative Action and Equal Protection: Hearings on S.J. Res. 41 Before the Subcomm. on the Constitution of the Senate Comm. on the Judiciary, 97th Cong., Ist Sess. (1981).

276. There was no effort made to overrule Weber in 1979-80, for obvious reasons. Any bill to overrule Weber in the House would have gone to an immediate graveyard in either the Judiciary or Education and Labor Committee, both of which were probably to the left of the House on this issue. In the Senate, the chairs of the Judiciary and Labor Committees (Senators Kennedy and Williams, respectively) would have killed any such bill in 1979-80. The situation changed in the Senate when 
The reenactment rule is somewhat less questionable. Under this rule, the Court finds support for following a precedent or agency decision because Congress had reenacted the statute without overruling the decision. This rule is less questionable because the gatekeepers are not able to prevent Congress itself from considering amendinents to the new statute (as they often can when there is no action altogether under the acquiescence rule). Thus, Congress' failure to overrule Griggs in 1972 has some significance, not just because the gatekeeping committees endorsed it in their reports, ${ }^{277}$ but also because each chamber had an opportunity to bring the matter up. In fact, the Senate did defeat an amendment seeking to bar race-conscious rehef in title VII that went well beyond Griggs. ${ }^{278}$ On the other hand, the reenactment rule should not apply if there is no sound reason to beheve that Congress was aware of the Court's decision.

Legislative inaction is most persuasive, and appears most rehable, in the context of a rejected proposal. Under the rejected proposal rule, the Court will infer legislative intent from the defeat of a proposal to overrule a precedent or agency decision. So long as the rejection occurs on the floor of a chamber or in conference committee, it often will be rehiable evidence of subsequent legislative preferences. Nevertheless, rejected proposals should always be approached critically. For example, the Court in Runyon v. McCrary rehed heavily on the Senate's rejection of a proposal which would have overruled cases applying Jones $v$. Mayer to employinent discrimination. ${ }^{279}$ The Court, however, did not exanine congressional actions in sufficient detail. It failed to note three crucial aspects: first, that the proposal was not opposed on the ground that anyone agreed with Jones $v$. Mayer; second, that the proposal was rejected on a tie vote; and third, that a majority of the Senators present actually favored the proposal, which was scuttled by a gatekeepers' gambit. ${ }^{280}$ While the Senate's action does provide some evidence of median legisla-

the Republicans took control in 1981. Senator Hatch introduced S.J. Res. 41 and held hearings on it in the Judiciary Subcounmittee, which he chaired. See supra note 275. But the committee was dominated by a pro-civil-rights coalition even during Republican control, see supra note 66, and S.J. Res. 41 went nowhere.

277. See supra notes 57-58 and accompanying text; see also 118 CoNG. REC. 7166 (1972) (conference report operated under assumption that "the present case law as developed by the courts would continue to govern the applicability and construction of title VII").

278. Senator Ervin proposed an amendinent to title VII to prohibit government agencies from requiring employers to adopt goals for the hiring of minorities. See 118 CoNG. REc. 1663-64 (1972). Senator Javits led the opposition, which defended all sorts of remedial practices that addressed Griggs-like bad numbers. Id. at 1664-76. The Ervin amendment was defeated by a two-to-one vote. Id. at 1676. See generally H. GRAHAM, supra note 22, at $439-43$ (describing the debate between Ervin and Javits).

279. Runyon v. McCrary, 427 U.S. 160, 174 n.11 (1976) (relying on the legislative history of the rejected proposal to legislatively overrule Jones $v$. Mayer).

280. This story, and more, is told in Eskridge, supra note 213 , at $100-03$. 
tor preferences in the early 1970s, the Runyon Court overstated its significance.

\section{B. Rethinking Judicial Activism}

The Supreme Court's conduct has confounded traditional legal thinking about judicial activism. ${ }^{281}$ Judicial activism has always been associated with the Warren Court, for it struck down many statutes to protect individual rights and interpreted statutes (especially civil rights statutes) dynamically and hiberally. The Burger Court, however, taught us that a moderate-to-conservative Court too could be activist-it also struck down numerous statutes and interpreted others just as dynamically as the Warren Court did (albeit in different ways). The Rehnquist Court is now teaching us that a conservative Court can be activist also in a different way. The Rehnquist Court is (thus far) not keen on invalidating legislation on constitutional grounds, but it is more aggressively activist in the context of statutory interpretation than was either the Warren or Burger Court.

This Article's positive analysis suggests a new way of thinking about judicial activism. Consider the following normative framework: The Court is activist in interpreting civil rights statutes when it emphasizes dynamic considerations beyond the statutory text and original intent, because im so doing the Court is going beyond the expectations of the enacting Congress. This dynamic interpretation can be politically productive activism if the Court's interpretation provides useful information about the statute to Congress or contributes to the statute's goals. The Court is even more activist if its interpretation emphasizes its own preferences over those of both the enacting and current Congress. This selfinterested interpretivism tends to be unproductive activism if the Court's preferences prove to be useless information or prove to thwart the statute's operation. The Court/Congress/President civil rights game developed in this Article suggests some interesting hypotheses for the various periods discussed.

\section{The Warren Court: $1962-72$}

In civil rights decisions, the Warren Court was quite activist, but perhaps not so activist as lawyers often suppose. Its interpretations of nimeteenth-century civil rights statutes certainly breathed new life into them. In most cases, the Court was interpreting very generalized statutes with little relevant legislative history. In addition, its dynamic interpretation refiecting current values strikes me as mild activism. ${ }^{282}$ The

281. I am using "judicial activism" in its traditional sense, to mean the Court's substituting its own preferences for those of elected representatives.

282. I am specifically thinking of Louisiana v. United States, 380 U.S. 145 (1965) (interpreting 
Court's liberal interpretations of title VII (Griggs) and of the Voting Rights Act (Allen) went beyond the original legislative expectations, but it is not clear that they went against those expectations. I would characterize the decisions as only moderately activist.

What is most striking about the Warren Court's dynamic interpretation of civil rights statutes is how politically productive it was. None of the decisions was overruled by Congress. Moreover, Guest and Louisiana, though dynamic interpretations, were codified and elaborated by Congress in statutes. Allen and Griggs were embraced as buildingblock interpretations by the legislature when it considered the voting rights extension in 1970 and title VII's amendment in 1972. In each case, the Court reached resnlts that were perceived as just, gave reasons that made sense, and helped stimnlate legislative responses to advance the statutory goals.

Although the Warren Court was probably to the left of Congress on most civil rights issues, its opinions proved persuasive and helped the Presidency move Congress to the left. To the extent that the Court and Congress worked so productively together (with critical leadership from the Presidency), the Warren Court's activism can be defended as not acutely countermajoritarian. It can also be characterized as politically astute. The Warren Court was in this way a very successful political actor in the Court/Congress/President civil rights game. This success is surely related to the substantial political experience of members of the Warren Court. ${ }^{283}$

\section{The Burger Court: $1972-86$}

The Burger Court strikes me as more activist than the Warren Court in construing civil riglits statutes. So far as I can tell, the Burger Court was no more faithful to original legislative intent than the Warren Court had been. Runyon, Weber, and Bob Jones were at least as dynamic on the hiberal side as any of the Warren Court's decisions; Gilbert, McMann, Bolden, Grove City, Robinson, and Atascadero were equally

42 U.S.C. § 1971) and United States v. Guest, 383 U.S. 745 (1966) (interpreting 18 U.S.C. § 241 as a valid remedy for conspiracies to deprive individuals of their fourteenth amendment rights). The most controversial decision, Jones v. Mayer, strikes me as inconsistent with original legislative intent. My conclusion, however, is not so firm in light of recent historiography supporting the Court's interpretation. See Sullivan, Historical Reconstruction, Reconstruction History, and the Proper Scope of Section 1981, 98 YALE L.J. 541, 546 n.36 (1989) (surveying the historiography).

283. The Justices on the 1960 s Warren Court were unusually experienced in the political arena. The "Super Chief" himself had been Governor of California for ten years and also the GOP's vicepresidential candidate in 1948. Others with substantial political experience were Justices Black (Senator from Alabama), Douglas (SEC Chair), Clark (Attorney General), Stewart (Mayor of Cincinnati), White (Deputy Attorney General), Goldberg (AFL-CIO Counsel, Secretary of Labor), and Fortas (presidential advisor). Justice Brennan, of course, proved the most politically savvy of all, although he never held elected or national political office. 
dynamic on the conservative side. None of these decisions is easily defensible as an exercise in discerning the original legislative intent, and, for the last six, the testimony of Members of Congress involved in the original legislation provides additional evidence that in any event the Court was not seriously trying to implement the original legislative intent. Indeed, Gilbert, Bolden, and Atascadero were apparent efforts by the Court to transplant its conservative constitutional jurisprudence into statutory cases. ${ }^{284}$ Unlike the Warren Court, whose statutory decisions tended to go "beyond" original legislative expectations, the Burger Court's civil rights decisions often went "against" original legislative expectations: They undermined the efficiency of the statutory schemes they interpreted. Acting against the original intent is arguably inore activist than going beyond original intent, because it actually substitutes the Court's preferences for those of the legislature. ${ }^{285}$

The Burger Court's activism was often politically unproductive, for two reasons: its opimons failed to reflect current legislative preferences any better than historical ones; and the opinions contained unpersuasive reasoning. The Court's view of preguancy discrimmation in Gilbertthat it is not gender discrimination because it divides the world into one group consistmg of pregnant women and another group consisting of men and women who are not pregnant-is bizarre. Not even employer groups bothered to defend it $\dot{m}$ the hearings on overruling Gilbert. In Bolden, the Court's failure even to come up with a position five Justices could accept, and the harsh approach of the plurality, created confusion and bewilderment im the voting rights area, one where the Court had traditionally been a productive leader. The Court's expansive view of state immunity in Atascadero can be defended as an effort to force Congress to deliberate more carefully before it abrogates state immunity. But the legislative overruling of Atascadero was so swift and perfunctory (there were no hearings) as to raise questions about whether it had a point at all.

Even though other Burger Court decisions were more productive, ${ }^{286}$ the Burger Court did suffer several overrulings at the hands of an outraged Congress. Its statutory opinions were both more activist and less

284. See Atascadero State Hosp. v. Scanlon, 473 U.S. 234, 237-47 (1985) (eleventh amendment jurisprudence critical to Court's new clear statement rule against interpreting statutes to allow lawsuits against the states); City of Mobile v. Bolden, 446 U.S. 55, 60-74 (1980) (interpreting Voting Rights Act section 2 in accord with Burger Court fiftecnth amendment precedents); General Elec. Co. v. Gilbert, 429 U.S. 125, 133-40 (1976) (interpreting title VII in pari materia with fourteenth amendment).

285. See Farber, supra note 20.

286. See, e.g., Bob Jones Univ. v. United States, 461 U.S. 574 (1983); United Steelworkers v. Weber, 443 U.S. 193 (1979); Monell v. Department of Social Servs., 436 U.S. 658 (1978); Runyon v. McCrary, 427 U.S. 160 (1976); Cannon v. University of Chicago, 441 U.S. 677 (1975); Alyeska Pipeline Serv. Co. v. Wilderness Soc'y, 421 U.S. 240 (1975). 
politically acceptable than those of the Warren Court. Under the normative scheme of the positive game, the Burger Court was a much less successful player than the Warren Court had been. One reason for the Burger Court's relatively poor performance is historical misforturie: The Warren Court may have been more hiberal than Congress in the 1960s, but the direction of Congress' movement was toward the Court, and not away from it. ${ }^{287}$ The Burger Court, in contrast, moved rightward as Congress was inoving leftward, and so the dynamics of pohitical discourse seemed to work against the Court after 1975. Also it appears that the Burger Court as a group was not quite as politically perceptive as the Warren Court had been. ${ }^{288}$

\section{The Rehnquist Court: 1986-Present}

Although it is too early to make definite assessinents of the Rehnquist Court's performance in civil rights cases, its decisions to date indicate that it is more activist than the Burger Court and significantly more activist than the Warren Court. Consider the controversial cases from the 1988 Term. None of the opinions even attempted to justify its results based upon originial legislative expectations. ${ }^{289}$ The outcry in Congress reinforces the arguments made by dissenting opmions that the Court followed an interpretive methodology "which is so inainpulative as virtually to invite the charge of result-orientation."290

It remains to be seen how productive the Rehnquist Court's activisin will be. Betts has already been legislatively overruled. There seems to be overwhehning bipartisan support for overruling Patterson and Lorance, and substantial bipartisan support for overrulmg or modifying

287. The Warren Court was of course lucky to have Presidents sympathetic to its civil rights agenda, and even luckier to have sympathetic gatekeepers in 1962-72-the Democratic leadership in both chambers, the House Judiciary Committee, and the Senate Education and Labor Committee.

288. To be sure, the Burger Court Justices were no strangers to the world of Washington politics. Warren Court holdover Justices Stewart, White, Brennan, and Marshall had sophisticated political instincts, and Chief Justice Burger had been an Assistant Attorney General. But his political abilities (building coalitions, leading the Conference, avoiding doomed political battles with Congress) are widely considered inferior to those of Chief Justice Warren. And among the other Justices appointed between 1969 and 1983, only Justice Powell had impressive political experience and instincts.

289. Martin v. Wilks, 490 U.S. 755 (1989), never acknowledged that it was implicitly construing title VII's remedial scheme. Wards Cove Packing Co. v. Atonio, 490 U.S. 642 (1989), engaged only in perfunctory analysis of the statutory text, as did Public Employces Retirement System v. Betts, 109 S. Ct. 2854 (1989). Patterson v. McLean Credit Union, 491 U.S. 164 (1989), not only ignored legislative intent, but also selectively relied on subsequent legislative developments. The Patterson Court interpreted section 1981 narrowly, in part because a broad reading might "circumvent" the detailed statutory scheme adopted in title VII. Id. at 181. Given the legislative belief after Runyon v. McCrary, 427 U.S. 160 (1976), that seetion 1981 wonld be an additional remedy in race discrimination cases, the Court's reliance on title VII seems arbitrary.

290. Betts, 109 S. Ct. at 2870 (Marshall, J., dissenting). 
Hopkins and Zipes. ${ }^{291}$ In addition, there is a good chance that Congress will modify Wards Cove and Martin v. Wilks, albeit not without considering the Court's values.

Obviously, the Rehnquist Court was (in 1989 anyway) not a very successful player of the Court/Congress/President civil rights game. Like prior Courts, it did not interpret civil rights statutes by trying to discern original legislative intent; but, unlike the Warren and Burger Courts, it often missed the tenor of current legislative majorities. I find it quite puzzhing that the Rehnquist Court might be less successful than the Burger Court. Although the Rehnquist Court is on the whole a sheltered group with unimpressive political experience, it is not vastly different from the Burger Court in its personnel. And the Rehnquist Court is historically lucky (for the timie being) to enjoy the support of a President significantly to the right of Congress. My hypothesis in response to this puzzle is tliat the Rehnquist Court inay currently be rethinking whether it wants to play this game, which was played (adroitly) by the Warren Court and (in a mediocre way) by the Burger Court. Consider the next Section.

\section{The New Textualism and the Future Role of the Court in National Civil Rights Policy}

The Rehnquist Court surely does not see itself as unusually activist and politically unpredictive. Some of the Justices on the Court (foremost among them Justice Scalia) have responded to these criticisms essentially by denying the legitimacy of the Court/Congress/President civil rights game tliat the Court has played for decades. According to the "new textualists" like Justice Scalia, tlie Court's role is not to implement the preferences of either the enacting or the current legislature, but to apply tlie "plain meaning" of the statutory text as passed by both chambers of Congress and presented to the President. ${ }^{292}$ The new textualism posits that truly "neutral" statutory interpretation does not consider the "subjective" preferences of Congress, only the "objective" meaning of a stat-

291. See 1990 Senate Civil Rights Hearings, supra note 171, at 5-6 (statement of Sen. Hatch), 7172 (statement of Prof. Fried), 111 (statement of Deputy Attorney Gcneral Ayer).

292. See Statutory Interpretation and the Uses of Legislative History: Hearing Before the Subcomm. on Courts, Intellectual Property, and the Administration of Justice of the House Comm. on the Judiciary, 101st Cong., 2d Sess. (1990) (hearings on new textualism); Eskridge, The New Textualism, 37 UCLA L. REV. 621 (1990) (discussing, inter alia, how the new textualism of Justice Scalia posits a radically different role for the Court); Ross, Reaganist Realism Comes to Detroit, 1989 U. ILL. L. REV. 399 (demonstrating how textualism and deference to administrative expertise currently favor the policies of a Republican administration over the policies of a Democratic Congress); Zeppos, Legislative History and the Interpretation of Statutes: Toward a Fact-Finding Model of Statutory Interpretation, 76 VA. L. REV. 1295 (1990) (criticizing the new textualism as insufficiently deferential to legislative preferences and proposing that such preferences be analyzed as judicially noticed "facts"). 
ute's words. If the plain meaning of the words runs counter to current legislative preferences, textualism's adlierents reason, Congress can always annend the statute. New textualists believe it is better (and indeed constitutionally required) for Congress to do the amending than for the Court to do so through "interpretation."

The new textualism is an ideologically significant development. By excluding evidence of actual legislative expectations (past or present), the new textualism signals that the Court may no longer be willing to play the positive gaine, and that it is willing to tolerate tension between itself and Congress. Elsewhere, I lave criticized the new textualism for failing to provide a persuasive justification for its rethinking of the Court's role. ${ }^{293}$ I only want to suggest three points here. First, as it has actually operated in civil rights cases, the textual analysis engaged in by the riglit wing of the Rehnquist Court lias not establislied its claims to objectivity. Second, textualisin is an inappropriate way for the Court to fulfill its inherently subordinate role in statutory policyinaking. And third, if the Court's embrace of the new textualism continues to move its decisions further from current legislative preferences, Congress might consider reinoving or diminishing the Court's role in civil riglits statutory interpretation.

\section{The New Textualism's Questionable Claim to Objectivity}

A problein witli textualisin is that words do not interpret themselves, and the general and norm-filled langnage often favored by statutory drafters offers a variety of interpretive clioices. How the statutory interpreter makes those clioices depends heavily on her own perspective and often on lier own preferences. The new textualists' claim that they can divine umversal, objective meaning from such langnage is therefore suspect. Their performance in recent civil riglits cases bears out this insight.

Recall Patterson, where the five-Justice majority lield that the racial liarassinent Brenda Patterson endured at the hands of her employer did not violate section 1981's right "to make and enforce contracts" irrespective of race. The Court's only rationale was that protecting Brenda Patterson's right to "make" a contract "extends only to the formation of a contract, but not to problems that inay arise later from the conditions of continuing employment,"294 and that protecting Patterson's riglit to "enforce" the contract only "prohibits discrimination that infects the legal process in ways thiat prevent one froin enforcing contract riglits."295 The Court cited no precedent or other authority to support its narrow

293. See Eskridge, supra note 292, at 669-78.

294. Patterson v. McLean Credit Union, 491 U.S. 164, 176 (1989).

295. Id. at 177 . 
interpretation of section 1981. Certainly, ordinary usage of the words "make" and "enforce" does not compel such a narrow reading. To say, as the Court did, that a broad statutory protection of a person's right "to make and enforce contracts" only applies to the original formation and to the legal process of contract enforcement is like saying that a sandwich consists only of two pieces of bread (and not the meat in the middle). To say that Brenda Patterson lias "the same right ... to inake . . . contracts ... as is enjoyed by white citizens" surely implies a right to nondiscriminatory terms throughout the duration of the employment contract, as a matter of plam meaning. To say that she has "the same right . . . to enforce . . . contracts . . . as is enjoyed by white citizens" explicitly protects her right to "give effect to" (the dictionary meaning of "enforce") a nondiscriminatory contract. This is all Brenda Patterson was claiming. Her interpretation of the plam meaning of section 1981 strikes me as more objective than that of the Court. Indeed, her reading is precisely the one that congressional critics of Jones v. Mayer felt was the plain meaning of the statute (and the reason they wanted it changed). ${ }^{296}$

Moreover, there is no persuasive reason to protect against racial discrimination in the acts of entering into a contract and suing upon a contract, without including the acts of performing the contract. Recall the facts of Runyon, which Patterson purported to reaffirm. In Runyon, the Court held that private segregated schools conld not refuse to adinit ("to make a contract" with) the parents of black children, under the plain meaning of section 1981. By implication, Runyon surely interprets section 1981 to prevent a school from admitting black children and then expelling them because of their race. It is virtually certain that the Court would have found that such expulsion would impair the children's ability to "enforce"-give effect to-their contracts. Yet Patterson disallows this imterpretation. Hence, Patterson is imternally incolierent: It explicitly reaffirms Runyon while simultaneously repudiating by implication a necessary part of Runyon's holding.

In Patterson, the new textualists do not even present plausible textual arguments for their position. The case exemplifies their most naked activism, namely, their willinguess to read a statute narrowly (contrary to its apparent textual meaning and precedent) based upon nothing more than their own policy preferences. Patterson, of course, may not represent the new textualist ideology at its best. Usually, the new textualists lave more plausible semantic arguments about the meaning of specific

296. In the debates on the 1972 amendments to title VII, Senator Hruska complained that unless his amendment were adopted to make title VII the exclusive remedy for job discrimination, "a black female employee [claiming] a denial of either a promotion or a pay raise . . . because of her color" could bypass title VII by filing "a complaint in Federal court under the provisions of the Civil Rights Act of 1866." 118 CoNG. Rec. 3368-69 (1972). Brenda Patterson was a "black female employee [claiming] a denial of . . . a promotion . . . because of her color." 
words, phrases, or sentences. ${ }^{297}$ Even when well articulated, however, their semantic arguments are more suggestive than conclusive and do not exclude other "textual" readimgs. Because the Patterson Court did not even bother to clothe its decision in plausible textualist arguments, its (anti-civil-rights) result orientation is manifest. Thus far in civil rights cases, I find hittle (or in Patterson, nothing) objective about the new textualists' results or reasoning. That the new textuahists' semantic arguments so often seein to favor defendants in civil rights cases further undermines the theory's claim to objectivity and neutrality. ${ }^{298}$

\section{False Modesty of the New Textualism}

Our systein of government still assumes that the Court is a subordimate player in statutory pohicymaking, and at least soine of the new textualists continue to argue that the Court is the "honest agent" of Congress. ${ }^{299}$ If this is so, the new textualism is not a very helpful approach to statutory interpretation. ${ }^{300}$ An honest agent does not consider himself bound by the narrowest, most hiteral meaning of the principal's commands, but instead seeks to carry out her commands in the context of the principal's original expectations, original goals, and even current expectations and goals-all as they relate to the situation at hand. An agent is neither competent nor faithful if he interprets the principal's command without really trying to move the enterprise forward. Thus, if the principal instructs the agent to make and enforce contracts for her (the Patterson situation), doesn't the agent know that he should monitor perforinance of the contracts? It is a pretty lame agent who sees monkey busmess going on in the operation of the contract and shrugs, "Well, that's too bad for the principal, but my orders were just to 'make and enforce' contracts, and I think they are pretty narrow commands."

In the context of this Article's game-theoretic analysis, the new textuahists would respond that the best course for the agent is to consult the

297. For narrowly literalist analysis by the new textualists in civil rights cases, see Public Employees Retirement Sys. v. Betts, 109 S. Ct. 2854, 2861-64 (1989) (Kennedy, J., for the Court) (interpreting term "subterfuge" according to "ordinary meaning" rather than considering legislative and statutory context); Independent Fed'n of Flight Attendants v. Zipes, 491 U.S. 754, 758-61 (1989) (Scalia, J., for the Court) (rewriting title VII fee-shifting provision without reference to legislative intent); Price WVaterhouse v. Hopkins, 490 U.S. 228, 279 (1989) (Kennedy, J., dissenting) (interpretation of "because of"); Johnson v. Transportation Agency, 480 U.S. 616, 669-77 (1987) (Scalia, J., dissenting) (criticizing Court's approach to statutory interpretation).

298. See Ross, supra note 292 (arguing that the new textualists' methodology systematically favors conservative values).

299. Easterbrook, The Supreme Court, 1983 Term-Foreword: The Court and the Economic System, 98 HARV. L. Rev. 4, 60 (1984).

300. See R. Posner, The Federal Courts: Crisis ANd Reform 291-93 (1985) (criticizing stingy textualist interpretation as not very helpful to legislative process). 
principal when there is ambiguity in the directive. ${ }^{301}$ Stringent textual interpretations of civil rights statutes that trigger legislative overrides can be useful, according to this ideology, insofar as they encourage clarification from the most legitimate party, the principal. What this response ignores is that overrides are costly. When the agent fails to monitor the contract's operation, those contract losses are lost to the principal even if she is able to correct the agent's misinterpretation later. And the whole point of having a sophisticated agent is that he will "act for" the principal, without having to bother the principal constantly with the details of inplementation.

Similarly, a Court that distorts the congressional civil rights policy and thereby triggers legislative overrides is usually behaving in a countermajoritarian way. It takes time for Congress to override the Court's errant interpretations, and during that time, victims of discrimination are deined the remedies that Congress has established and, indeed, wants them to have. Sometimes, Congress will not override decisions it disagrees with, either because well-placed opposition (Senate filibuster, a hostile gatekeeping committee in either chainber, or a presidential veto) makes enactment unlikely or because the legislative agenda is already full. As the experiences in 1988 and 1990 have shown us, overriding the Court's statutory civil rights decisions is a mine field and usually requires substantial effort that would be better spent correcting new problems, not reiterating agreed-upon solutions to old ones. This is the inost serious mdictment of the Rehnquist Court's activism: by clogging the legislative agenda with issues settled yesterday, the Court is distracting Congress froin understanding and addressing the tough civil rights issues of today and tomorrow.

\section{Shifting Responsibility for Civil Rights Interpretation Away From the Court}

The inost important inplication of our game-theoretic model is that if the Court is reluctant or obstructive in its implementation of congressional civil rights pohicy, Congress should consider establishing procedural rules to limit the Court's role. An important theine of positive pohitical theory is that Congress can exercise control over its "agents" in how it structures "agency" procedures. ${ }^{302}$ Because the Court is harder to discipline than executive departments or independent commissions,

301. The new textualists are not wont to find much ambiguity, however. See Scalia, Judicial Deference to Administrative Interpretation of Law, 1989 DUKE L.J. 511, 521 (indicating a propensity to find unambiguous statutory meaning).

302. Moe, Control and Feedback in Economic Regulation: The Case of the NLRB, 79 AM. POL. ScI. Rev. 1094 (1985); Weingast \& Moran, Bureaucratic Discretion or Congressional Control: Regulatory Policymaking by the Federal Trade Commission, 91 J. PoL. EcoN. 765 (1983). 
this strategy might not work as well-and indeed it might clash with the checks and balances function of an independent judiciary-but several proposals bear consideration.

Probably the least useful is the rule, floated in the vetoed 1990 bill and in the proposed 1991 bill, directing the Court to interpret civil rights statutes "broadly" and to reflect legislative "intent." 303 Apart from the constitutional problems with such a rule, ${ }^{304}$ it is hard for ine to see how it would inake much difference. Justice Kennedy, the author of Patterson, probably thought he was construing section 1981 broadly and consistently with the legislative intent (as he read it in the plain meaning of the statute's text). Should any of the cases mentioned in this Article be reconsidered under the broad construction rule, at least one-Weberwould probably be decided differently. Weber, after all, was a "narrow" interpretation of title VII's prohibition of discrimination, which is hard to square with original legislative "intent." (That would probably surprise the sponsors of the 1990 and 1991 bills!) In any event, this sort of interpretational "rule" would probably not make the Court a more cooperative player in the game outlined in this Article.

Rather than legislating such a general rule, Congress should consider more structural rules for civil rights cases. For exainple, Congress might be more specific about information it wants the Court to consider. An interpretation statute might require the Court to consider committee reports when construmg civil rights statutes, to solicit amicus curiae briefs from designated public interest groups and the U.S. Civil Rights Commission, and to solicit information on the effect of the proposed interpretations on the ability of victims of discrimination to obtain effective redress. The difference between this sort of interpretation statute and the one contained in the 1990 and 1991 bills is that it not only gives a strong signal to the Court (as the current bills do), but also invites or requires the Court to become better informed about American civil rights policy. Information theory suggests (persuasively, to me) that confronting information itself can shift preferences in at least some cases.

Along precisely these lines is the suggestion that Congress shift responsibility for interpreting civil rights statutes from article III courts to one or more administrative agencies. There are several ways Congress can try to do this. The most logical approach would be to vest one or

303. As finally passed (and vetoed), the 1990 bill provided in section 1107(a): "All Federal laws protecting the civil rights of persons shall be interpreted consistent with the intent of such laws, and shall be broadly construed to effectuate the purpose of such laws to provide effective . . remedies." 136 CONG. REC. H9554 (daily ed. Oct. 12, 1990) (emphasis added). This language has been carried over in H.R. 1, 102d Cong., 1st Sess. $\$ 1107$ (1991).

304. That is, it might be argued (though I am not persuaded) that such a rule represents a legislative usurpation of article III judicial functions. See R. Dickerson, The INTERPRETATION AND APPLication OF STATUTES 262 (1975). 
more existing agencies (such as the EEOC) with formal rulemaking authority and legislate a very restrictive standard for judicial review. This approach has the advantage of building upon the Court's own precept of deferring to administrative interpretation of regulatory statutes. ${ }^{305}$ The Court has tended to ignore that precept when agencies charged with enforcing civil rights laws try to help victims of discrimination (usually the Court relies upon the pretext that Congress did not give the agency "formal" rulemaking authority). ${ }^{306}$ Giving agencies formal rulemaking authority would shift the responsibility for fleshing out and updating civil riglits laws from an increasingly conservative Court to agencies that might better reflect and respond to congressional preferences.

This strategy, of course, will not guarantee that civil rights policy will be set at the congressional median (M). A conservative President can use his executive authority or his appointment and OMB review authority to press any agency to the right of the congressional inedian. The President can then use the veto threat to protect the agency from being overruled. Hence, pohicy might end up closer to the veto median (V) than to Congress' preferred point (M).

This scenario, however, is hardly inevitable. First, Congress can build a pro-civil-riglits bias into the procedures the agency must follow to make policy and conduct adjudications. For instance, Congress might require the agency to consider the views of specified groups in the civil rights community. Or it might provide funding for reports on the impact of proposed rules on discrimination victims and on their access to justice. It might also allocate decisionmaking responsibility among long-term civil service personnel (such as administrative law judges) as well as political appointees. Second, Congress has more leverage over an agency than it has over the Court. Through oversight hearings, appropriations bills, and informal means of communication, Congress can influence agency policy to shift in the direction of congressional preferences.

Moreover, in a decade during which the Court's preferences concerning civil rights will surely lie significantly to the right of Congress' preferences, Congress may be better off with agency-driven policy even if the agency follows presidential, rather than congressional, direction. An agency that is controlled by a conservative Presidency and which sets

305. Chevron U.S.A. Inc. v. Natural Resources Defense Council, Inc., 467 U.S. 837 (1984) (deferring to EPA's construction of the Clean Air Act Amendments of 1977, when Congress had not directly addressed the question at issue); see Diver, Statutory Interpretation in the Administrative State, 133 U. PA. L. REv. 552 (1985) (arguing from a utilitarian perspective that courts "should presumptively defer to agency interpretations of statutes in situations where Congress has endowed the agency with significant policymaking responsibility").

306. See General Elec. Co. v. Gilbert, 429 U.S. 125 (1976) (refusing to defer to EEOC on pregnancy issue). 
policy at the veto median (V) is preferable to a Court that sets policy to the right of the veto median (V). In other words, Congress prefers an interpreter that will play the Court/Congress/President civil rights game (an agency) to one that refuses to play it (the Court in 1989) or plays it badly (the Court in Gilbert or Grove City). Congress' agenda is simply too crowded to permit the repeated overruling of judicial interpretations of civil rights statutes. In addition, Congress can work more productively with an agency, whicl is well-informed about legislative preferences and the dynamics of civil rights, than with a Court that has demonstrated an mability or unwillingness to be cooperative. On the other hand, under a moderate or liberal Presidency, agency pohicymaking would quickly shift toward the congressional median (M), wliereas a shift in the Court's preferences would probably take years and require appointments by a series of moderate or liberal Presidents as space on the Court becomes available.

\section{CONCLUSION: RENEGING ON HISTORY?}

Contrary to some statements made in the congressional debates in 1990, the Court's 1989 civil rights decisions have a certain continuity with what came before. The Court in Patterson and the other 1989 decisions was not faithfully seeking original legislative intent or neutrally applying the statutes' plain meaning. But, then, the Court has never acted that way in civil rights statutory interpretation. This sort of judicial activism in statutory interpretation is nothing new.

The Court that decided Patterson and the other 1989 decisions was producing results that did not reflect current legislative preferences. However, this was also true of the Warren Court (which thrived on sucl independence and never got overruled) and was often true of the Burger Court (which in almost every instance was promptly overruled). Therefore, again, ignoring current legislative preferences is nothing new. Finally, the Rehnquist Court approached Patterson and the other 1989 decisions from a perspective substantially more conservative than that of Congress. But tliat has been true of the Court since 1972, when Justices Rehnquist and Powell started voting.

Despite these points of continuity, there remains a deep sense of rupture, a dramatic unsettling of things in our political system, because of the 1989 civil rights decisions. The game-theory model of the Court/ Congress/President dynamics in statutory interpretation is a formal (and of course incomplete) way of expressing this rupture. The big change in 1989 was the Court's seeming unwillingness, in a series of high-visibility cases, to play the game. In the short term, the Court's "attitude" has produced an intense political conflict involving all three branches of gov- 
ernment. In the long term, I doubt the Court will sustain its uncooperative attitude, because the game is important to the Court as well.

The 1989 rupture ought to awaken the civil rights community to the fact that the Supreme Court is no longer the most appropriate mechainsm for advancing progressive civil rights policies through statutory interpretation. This has been true for some time. The 1989 decisions dramatically confirmed exactly how far to the right the Court has drifted. The challenge for Congress and civil rights groups in the 1990s is to develop alternative approaches for implementation that do not depend upon the Court's cooperation. The Court has, as Republican Senator Jeffords charged, "reneged on history." 307 Like previous Courts, the Rehnquist Court has substituted its policy preferences for those of the enacting Congress. But it has also "reneged" on the historical tradition by which the Court has long attended to the preferences of Congress. This is a breach of political faith that underlies the sense of betrayal felt by Senator Jeffords and others. It remains to be seen whether that breach of faith will stimulate a larger rethinking of decisionmaking power to implement our nation's civil rights agenda.

307. 136 CONG. REC. S1022 (daily ed. Feb. 7, 1990). 